
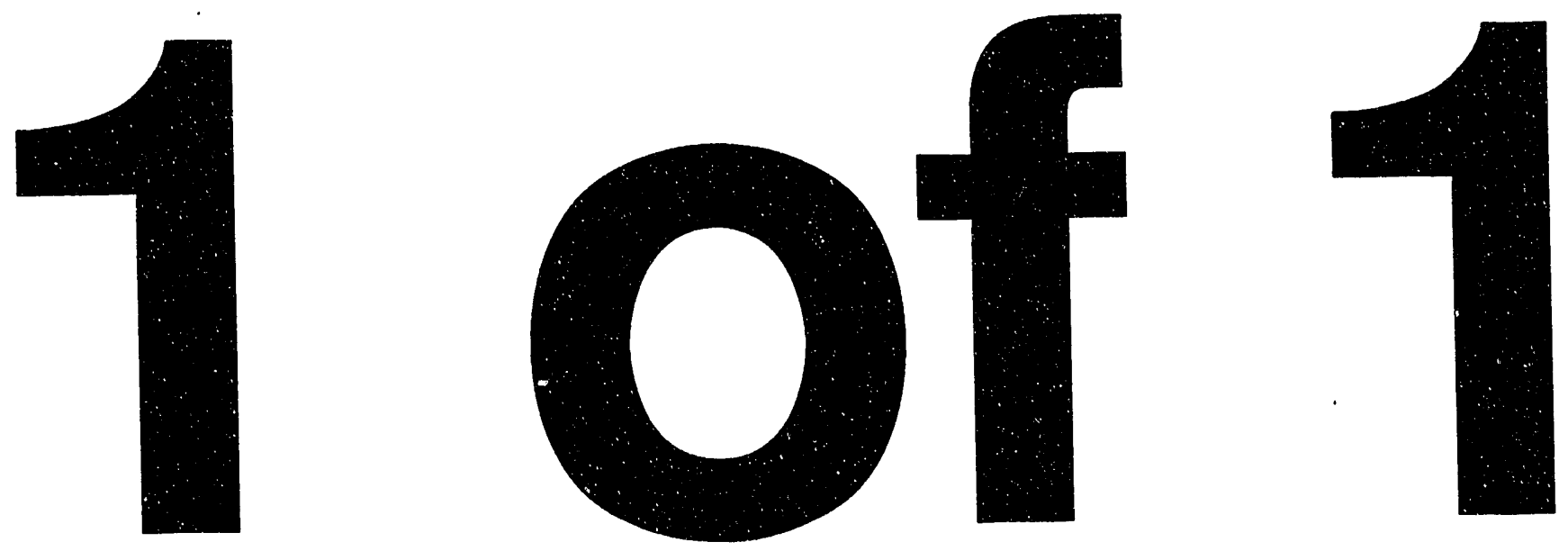


\section{Technical and Regulatory Review of the Rover Nuclear Fuel Process for Use on Fort St. Vrain Fuel}

T. Hertzler

Published February 1993

Science Applications International Corporation

P.O. Box 50697

Idaho Falls, Idaho 83405

Prepared for EG\&G Idaho, Inc. and U.S. Department of Energy

Office of Environmental Restoration and Waste Management Under DOE Idaho Fleld Office Contract DE-AC07-76ID01570 


\section{Technical and Regulatory Review of the Rover Nuclear Fuel Process for Use on Fort St. Vrain Fuel}

EGG-WTD-10550

Prepared by

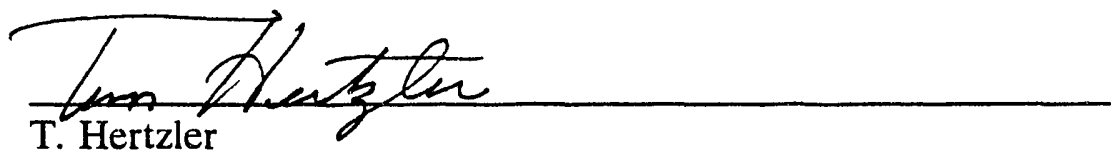

Science Applications International Corporation

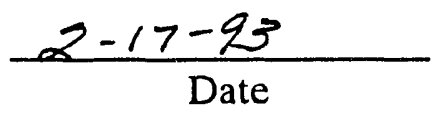

Reviewed by

R. Hobbins, Principal Engineering Specialist

Fuels and Materials Unit

Date

Approved by

J. M. Beller, Senior Project Engineer

Date

Environmental Restoration Technology Development 


\begin{abstract}
This report describes the results of an analysis for processing and final disposal of Fort St. Vrain (FSV) irradiated fuel in Rover-type equipment or technologies. This analysis includes an evaluation of the current Rover equipment status and the applicability of this technology in processing FSV fuel. The analyses are based on the physical characteristics of the FSV fuel and processing capabilities of the Rover equipment. Alternate FSV fuel disposal options are also considered including fuel-rod removal from the block, disposal of the empty block, or disposal of the entire fuel-containing block.

The results of these analyses document that the current Rover hardware is not operable for any purpose, and any effort to restart this hardware will require extensive modifications and re-evaluation. However, various aspects of the Rover technology, such. as the successful fluid-bed burner design, can be applied with modification to FSV fuel processing.

The current regulatory climate and technical knowledge are not adequately defined to allow a complete analysis and conclusion with respect to the disposal of intact fuel blocks with or without the fuel rods removed. The primary unknowns include the various aspects of fuel-rod removal from the block, concentration of radionuclides remaining in the graphite block after rod removal, and acceptability of carbon in the form of graphite in a high level waste repository.
\end{abstract}




\section{SUMMARY}

The Fort St. Vrain (FSV) power reactor was a high temperature, helium-cooled reactor located in Platteville, Colorado. It began operation in 1974 under control of the Public Service Company of Colorado with a rated power of $842 \mathrm{MW}$ thermal. The reactor fuel is a graphite moderator block containing $93.5 \%$ enriched ${ }^{235} \mathrm{U}$ and ${ }^{232} \mathrm{Th}$ in a carbide form $(\mathrm{U} / \mathrm{Th}) \mathrm{C}_{2}$. The FSV reactor was primarily designed and built to prove the feasibility of large-scale power producing high temperature gas-cooled reactor concept. Operational history of the reactor was characterized by low availability and inconsistent power production because of design deficiencies and lack of industry-wide experience to foresee and correct the deficiencies. Currently, the FSV reactor is being converted from a nuclear fueled power plant to a conventional fossil fuel facility. The reactor core is being dismantled, and the fuel elements will go into ternporary storage at the Irradiated Fuel Storage Facility at Idaho Chemical Processing Plant (ICPP) in Idaho and FSV onsite facility in Platteville. Currently, 742 of 2,208 fuel elements are stored at ICPP with the remaining at the FSV site.

Research and development on Rover-type fuels processing was carried out by the Oak Ridge National Laboratory in the early 1960s. Several reprocessing technologies (e.g., $90 \% \mathrm{HNO}_{3}$ disintegrations, grind-leach, and deline-burn-dissolve) were thoroughly evaluated before selection of a burn-leach process involving combustion of the graphite fuel rod matrix and dissolution of the burner ash to recover the uranium. The Rover process is based on three considerations: (1) primary and secondary burning of the fuel in fluidized bed burners to eliminate the graphite matrix and oxide the uranium and niobium carbides, (2) separation of the heavy metal oxides produced in the burning stage from the inert alumina bed material before dissolution, and (3) dissolution of the uranium rich ash from the secondary burner to produce an aqueous solution containing the recoverable uranium.

In 1988, the status of the Rover equipment and material remaining in the dry system was evaluated to support or oppose the potential reuse of the Rover facility. Westinghouse Idaho Nuclear Company conducted the investigation, determined that the Rover system was not reuseable, and recommended that it be decontaminated and decommissioned.

This report analyzes options for processing or disposal of the FSV fuel intact-block disposal in a high-level waste repository, separation of the fuel rods from the graphite block with subsequent appropriate processing, or disposal of each of the fuel element components (e.g., empty block, fuel rods, or fuel kernels). Fuel element component disposition may occur through combustion of the carbon, packaging for disposal, recovery of heavy-metal values, and disposal of the fission products. The analyses conducted in this report are based on the physical characteristics of the fuel and processing capabilities of the Rover equipment. The conclusions drawn in this report are

1. The Rover equipment and facility does not support reuse and efforts to restart will require extensive modification.

2. Burner technology exists that will incinerate the graphite block and matrix material, and a liquid-liquid extraction technology exists for recovery of the heavy metal values. The question to be resolved is whether there is a realistic option for disposal of the fuel particles resulting from head-end crushing and burning rather than processing to extract and recover the heavy metals. 
3. Further evaluation is required to determine the best methodology and technology to treat and/or dispose of the FSV fuel. Specific recommendations where additional evaluation is necessary are also provided.

A discussion of the different regulatory rules/standards that are applicable to graphite waste management activities is included. The Clean Air Act (CAA) is the regulatory statute for any process or activity that will generate air emissions. The CAA requires the Environmental Protection Agency to establish regulatory standards for all toxic or hazardous air pollutants under the National Emission Standards for Hazardous Air Pollutants (NESHAPs). Within NESHAPs, limits have been set for radioactive emissions from the U.S. Department of Energy, Nuclear Regulatory Commission, and other Federal facilities. The Rover and FSV graphite fuels contain radionuclides that are regulated relative to their emissions from a treatment, storage, or disposal facility. A commercial incineration processing option would be controlled by these regulations. 


\section{CONTENTS}

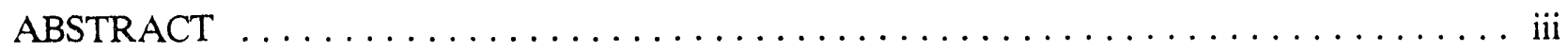

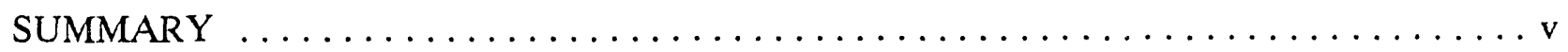

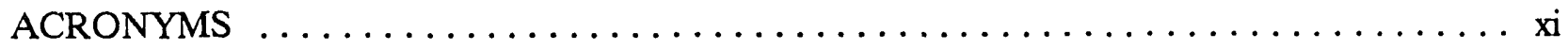

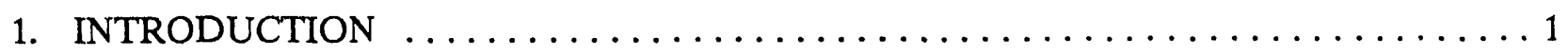

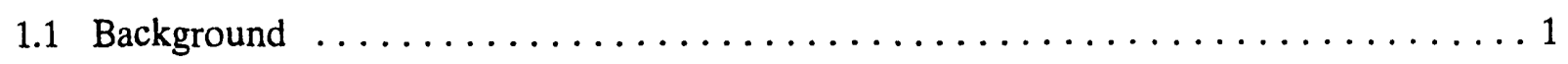

1.2 Characterization of Rover Fuel $\ldots \ldots \ldots \ldots \ldots \ldots \ldots \ldots \ldots \ldots \ldots \ldots \ldots \ldots \ldots \ldots \ldots$

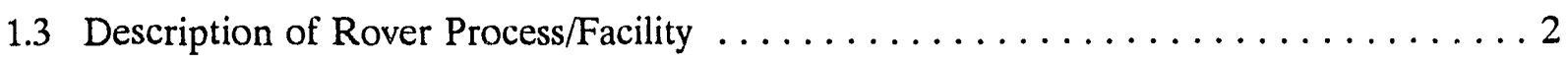

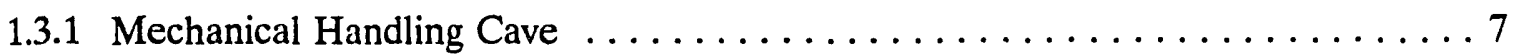

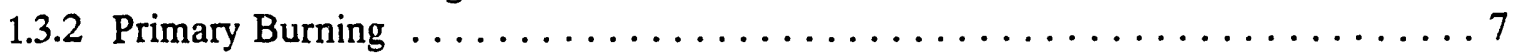

1.3.3 Secondary Burning $\ldots \ldots \ldots \ldots \ldots \ldots \ldots \ldots \ldots \ldots \ldots \ldots \ldots \ldots \ldots \ldots$

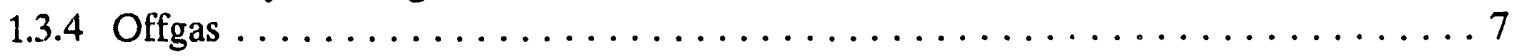

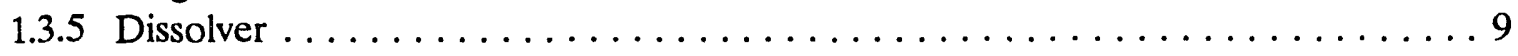

2. ROVER PROCESS AND FACILITY STATUS $\ldots \ldots \ldots \ldots \ldots \ldots \ldots \ldots \ldots \ldots$

2.1 Condition of Existing Equipment/Facility $\ldots \ldots \ldots \ldots \ldots \ldots \ldots \ldots \ldots \ldots \ldots$

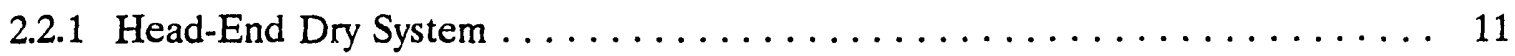

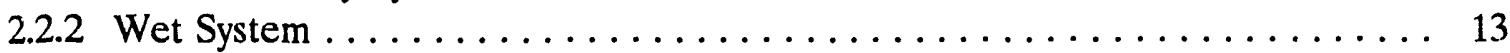

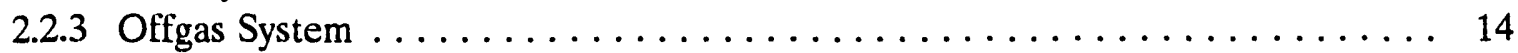

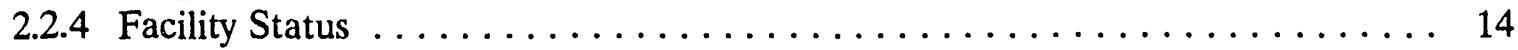

2.2 Chemical and Physical Effectiveness of the Rover Process $\ldots \ldots \ldots \ldots \ldots \ldots$

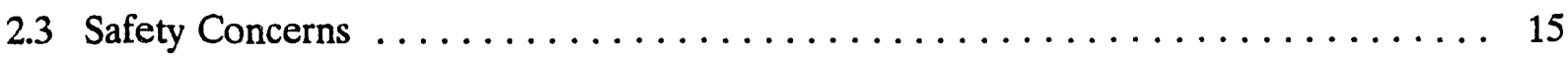

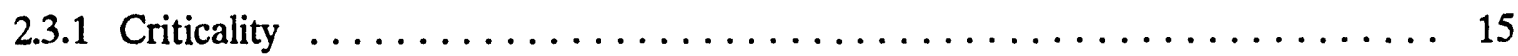

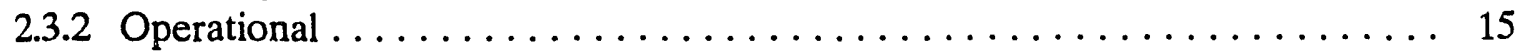

3. CHARACTERIZATION OF FORT ST. VRAIN FUEL $\ldots \ldots \ldots \ldots \ldots \ldots \ldots \ldots$

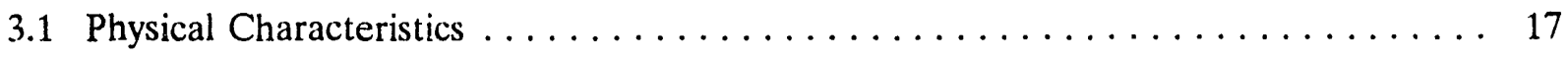

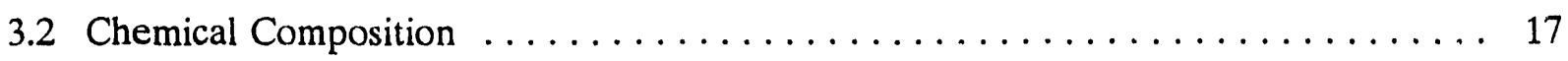

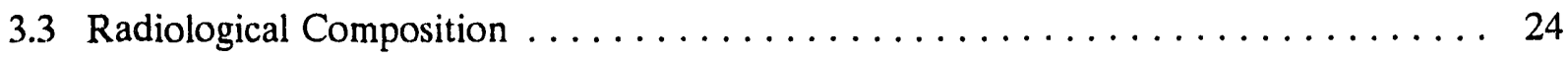


4. REGULATORY REQUIREMENTS $\ldots \ldots \ldots \ldots \ldots \ldots \ldots \ldots \ldots \ldots \ldots \ldots$

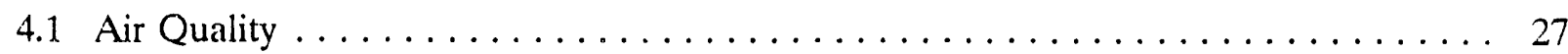

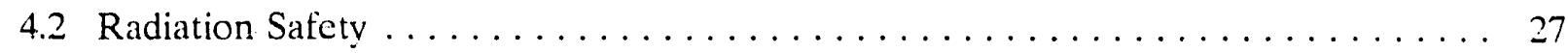

4.3 Resource Conservation and Recovery Act Applicability $\ldots \ldots \ldots \ldots \ldots \ldots$

4.4 National Environmental Policy Act Applicability $\ldots \ldots \ldots \ldots \ldots \ldots \ldots \ldots$

4.5 Low-Level Waste Regulations $\ldots \ldots \ldots \ldots \ldots \ldots \ldots \ldots \ldots \ldots \ldots \ldots$

4.6 Geologic Repository Waste Acceptance Regulations . . . . . . . . . . . 30

5. ALTERNATIVES IDENTIFICATION $\ldots \ldots \ldots \ldots \ldots \ldots \ldots \ldots \ldots \ldots \ldots \ldots$

5.1 Modifications to Rover Technology $\ldots \ldots \ldots \ldots \ldots \ldots \ldots \ldots \ldots \ldots \ldots \ldots \ldots$

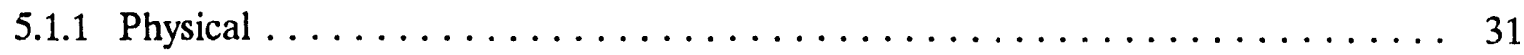

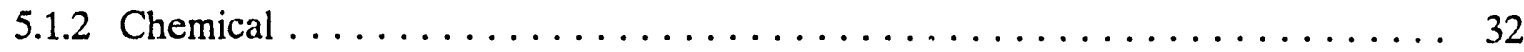

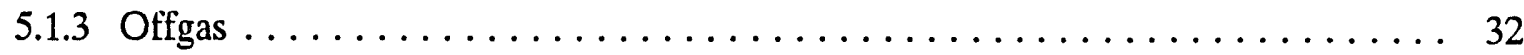

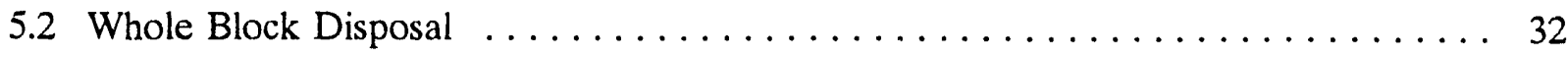

5.3 Whole Block Crush-Burn Processing $\ldots \ldots \ldots \ldots \ldots \ldots \ldots \ldots \ldots \ldots \ldots$

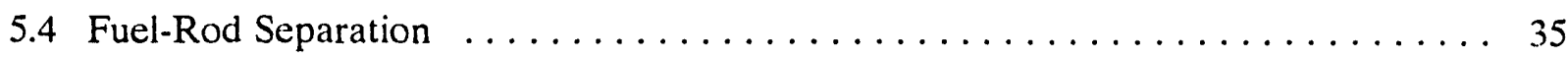

5.4 .1 Processing Options Flow Diagram $\ldots \ldots \ldots \ldots \ldots \ldots \ldots \ldots \ldots \ldots \ldots$

6. CONCLUSIONS AND RECOMMENDATIONS $\ldots \ldots \ldots \ldots \ldots \ldots \ldots \ldots \ldots$

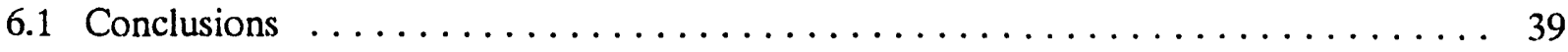

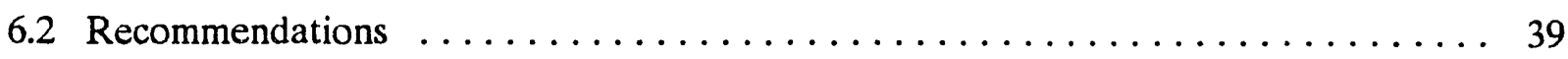

7. REFERENCES $\ldots \ldots \ldots \ldots \ldots \ldots \ldots \ldots \ldots \ldots \ldots \ldots \ldots \ldots \ldots \ldots \ldots \ldots$

Appendix A-Processing Literature $\ldots \ldots \ldots \ldots \ldots \ldots \ldots \ldots \ldots \ldots \ldots \ldots \ldots \ldots \ldots \ldots \ldots \ldots \ldots$

Appendix B-Estimated Radionuclide Activity in Fort St. Vrain Standard Full Elements ... . B-1

\section{FIGURES}

1. Fuel configuration in cardboard tubes and sketches of fuel shapes $\ldots \ldots \ldots \ldots \ldots$

2. Rover fuels processing facility $\ldots \ldots \ldots \ldots \ldots \ldots \ldots \ldots \ldots \ldots \ldots \ldots \ldots$ 


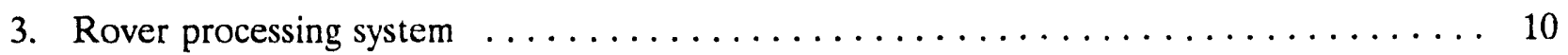

4. FSV standard fuel element $\ldots \ldots \ldots \ldots \ldots \ldots \ldots \ldots \ldots \ldots \ldots \ldots \ldots$

5. Control fuel elements and surveillance control element $\ldots \ldots \ldots \ldots \ldots \ldots \ldots$

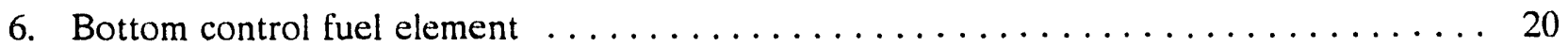

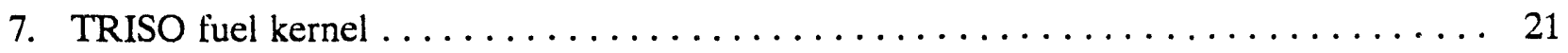

8. Processing and disposal options for Fort St. Vrain fuel $\ldots \ldots \ldots \ldots \ldots \ldots \ldots$

\section{TABLES}

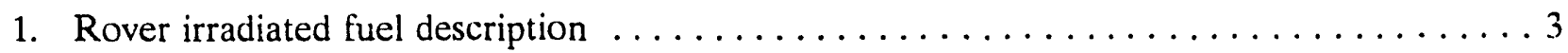

2. Rover fission product activities $\left(\mathrm{Ci} / 24 \mathrm{~kg}\right.$ of original $\left.{ }^{235} \mathrm{U}\right) \ldots \ldots \ldots \ldots \ldots$

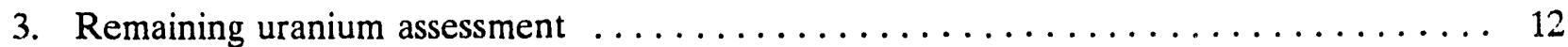

4. Fort St. Vrain fuel element component weights $\ldots \ldots \ldots \ldots \ldots \ldots \ldots \ldots \ldots \ldots$

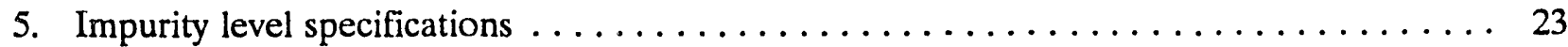

6. Fort St. Vrain fuel radionuclide inventory $(\mathrm{Ci} / \mathrm{MTIHM}) \ldots \ldots \ldots \ldots \ldots \ldots$

7. Concentrations for long-lived radionuclides $\ldots \ldots \ldots \ldots \ldots \ldots \ldots \ldots \ldots \ldots \ldots$

8. Concentrations for short-lived radionuclides $\ldots \ldots \ldots \ldots \ldots \ldots \ldots \ldots \ldots \ldots \ldots$ 


\section{ACRONYMS}

\begin{tabular}{|c|c|}
\hline $\mathrm{ADM}$ & Action Description Memorandum \\
\hline APS & Atmospheric Protection System \\
\hline BOG & Burner offgas \\
\hline BWR & Boiling water reactor \\
\hline CAA & Clean Air Act \\
\hline DOE & U.S. Department of Energy \\
\hline EPA & Environmental Protection Agency \\
\hline $\mathrm{FE}$ & Fuel element \\
\hline FSV & Fort St. Vrain \\
\hline GAC & General Atomic Company \\
\hline GTCC & Greater than Class-C \\
\hline HEPA & High efficiency particulate air \\
\hline HLW & High Level Waste \\
\hline HTGR & High temperature gas-cooled reactor \\
\hline ICPP & Idaho Chemical Processing Plant \\
\hline IFSF & Irradiated Fuel Storage Facility \\
\hline IHM & Initial heavy metal \\
\hline LLW & Low level waste \\
\hline LWR & Liquid water reactor \\
\hline MTIHM & Metric ton of initial heavy metal \\
\hline NEPA & National Environmental Policy Act \\
\hline NESHAPs & National Emission Standards for Hazardous Air Pollutants \\
\hline NRC & Nuclear Regulatory Commission \\
\hline
\end{tabular}




$\begin{array}{ll}\text { ORNL } & \text { Oak Ridge National Laboratory } \\ \text { OSHA } & \text { Occupational Safety and Health Administration } \\ \text { PIE } & \text { Post Irradiation Examination } \\ \text { PWR } & \text { Pressurized water reactor } \\ \text { PyC } & \text { Pyrolytic carbon } \\ \text { R\&D } & \text { Research and development } \\ \text { RCRA } & \text { Resource Conservation and Recovery Act } \\ \text { WINCO } & \text { Westinghouse Idaho Nuclear Company }\end{array}$




\section{Technical and Regulatory Review of the Rover Nuclear Fuel Process for Use on Fort St. Vrain Fuel}

\section{INTRODUCTION}

The successful aspects and experiences gained from the Rover process can be applied to the processing of existing Fort St. Vrain (FSV) high temperature gas-cooled reactor (HTGR) fuel. Utilizing the Rover technology for processing FSV fuel involves combustion of carbon and handling of either silicon-carbide coated fuel kernels as a waste or complete recovery of the heavy-metal values. The options for processing or disposal of the FSV fuel also include a number of variations ranging from intact-block disposal in a high level waste (HLW) repository, separation of the fuel rods from the graphite block with subsequent appropriate processing, or disposal of each of the fuel element components (e.g., empty block, fuel rods, or fuel kernels). Fuel element component disposition may occur through combustion of the carbon, packaging for disposal, recovery of heavymetal values, and disposal of the fission products. These options are discussed in following sections.

\subsection{Background}

The Nuclear Rocket Development Program was operated by the U.S. Atomic Energy Commission in the 1950s and 1960s to test the feasibility of a nuclear powered rocket for space flight. The tests were conducted at the Nevada Test Site near Las Vegas, Nevada. The Rover fuel used in these reactor experiments was a highly enriched uranium, $93.15 \%$ enriched ${ }^{235} \mathrm{U}$, fuel distributed in a graphite matrix. Several different prototype reactors were tested (e.g., Kiwi, NRX, Pheobus), and several different fuel element configurations were used. The Rover processing facility was established and operated in the early 1980s at the Idaho National Engineering Laboratory's (INEL's) Idaho Chemical Processing Plant (ICPP) to process the spent nuclear fuel (Rover fuel) used in the Nuclear Rocket Development Program. The product of the Rover process was an aqueous, uranium-bearing solution suitable for extraction and recovery of the uranium in existing ICPP liquid-liquid extraction equipment. Recycling of $3,200 \mathrm{~kg}$ of uranium estimated at a value of $\$ 125$ million was the objective of the Rover project. ${ }^{1}$

Considerable research and development on Rover-type fuels processing was carried out by the Oak Ridge National Laboratory (ORNL) in the early 1960s. Several reprocessing technologies (e.g., $90 \% \mathrm{HNO}_{3}$ disintegrations, grind-leach, and deline-burn-dissolve) were thoroughly evaluated before selection of a burn-leach process involving combustion of the graphite fuel rod matrix and dissolution of the burner ash to recover the uranium..$^{2-6} \mathrm{~A}$ listing of the reports covering the development and testing of these potential options is included in Appendix A with other related Rover and HTGR documents and reports.

The FSV power reactor was a high temperature, helium-cooled reactor located in Platteville, Colorado. It began operation in 1974 under control of the Public Service Company of Colorado with a rated power of $842 \mathrm{MW}$ thermal. The reactor fuel is a graphite moderator block containing $93.5 \%$ enriched ${ }^{235} \mathrm{U}$ and ${ }^{232} \mathrm{Th}$ in a carbide form $(\mathrm{U} / \mathrm{Th}) \mathrm{C}_{2}$. The FSV reactor was primarily designed and built to prove the feasibility of large-scale power producing HTGR concept. Operational history of the reactor was characterized by low availability and inconsistent power production because of 
deficiencies in design and the lack of an industry-wide experience base to foresee and correct these deficiencies. ${ }^{7}$ Currently, the FSV reactor is being converted from a nuclear fueled power plant to a conventional fossil fuel facility. The reactor core is being dismantled, and the fuel elements will go into temporary storage at two storage facilities built specifically for FSV fuel: the Irradiated Fuel Storage Facility (IFSF) at ICPP in Idaho and a facility onsite in Platteville. Currently, 742 of the 2,208 fuel elements are in storage at ICPP with the remaining at the FSV site. ${ }^{8}$

\subsection{Characterization of Rover Fuel}

The Rover fuel was a graphite matrix fuel element with homogeneously distributed uranium carbide $\left(\mathrm{UC}_{2}\right)$ fuel. Several different types of reactor fuel elements were developed in support of the Rocket Program. Table 1 gives a summary of the fuel types, their respective quantities, shape, size, and weight of uranium. All fuel elements were basically similar in configuration and composition except the Kiwi-A fuel elements, which were flat circular plates $8.5 \mathrm{in}$. in diameter. The average composition of the fuel was $75 \%$ carbon, $15 \%$ uranium, and $10 \%$ niobium. The niobium, as $\mathrm{NbC}$, was used to line the coolant holes to protect the fuel from the hydrogen propulsion gas passing through the nuclear core. During the lining process, 2 to $5 \%$ of the uranium diffuses into the niobium, creating a uranium-niobium compound (UC-NbC). ${ }^{3}$ The first generation fuel rods contained uranium carbide homogeneously distributed throughout the graphite matrix. The second generation fuel elements contained microspheres of uranium-carbide encased in pyrolitic carbon (PyC). which were also homogeneously dispersed within the graphite matrix. The UC-NbC compound and coating change affected the initial aqueous processing options of nitric acid $\left(\mathrm{HNO}_{3}\right)$ dissolution because this process would not dissolve the resulting niobium-uranium compound or the PyC coating effectively.

The Kiwi A, Kiwi A', and Kiwi B-1B were of first generation composition (i.e., no PyC layers). The remaining fuel element types listed in Table 1 contained the $\mathrm{UC}_{2}$ in $\mathrm{PyC}$ coated kernels. The variation in size, shape, and number of coolant channels did not significantly impact the burn-leach processing of the fuel. The Kiwi-A plates were broken into particles and packaged in the cardboard processing tubes specified for the Rover process. Figure 1 shows the fuel element shapes and packaging arrangement in 2.75 -in. cardboard processing tubes. The concentration of ${ }^{235} \mathrm{U}$ varied between rod types, with the highest being $160 \mathrm{~g}{ }^{235} \mathrm{U}$ per fuel rod. ${ }^{1}$

The fission product activities in the Rover fuel is provided in Table 2. ${ }^{1}$ The activity presented in Table 2 is based on the Rover plant design feed rate of $24 \mathrm{~kg}$ of initial ${ }^{235} \mathrm{U}$. The activity for the maximum case corresponds to an approximate burnup of $0.1 \%$ and 9.5 -year decay time, while the average case corresponds to an approximate burnup of $0.01 \%$ and 14 -year decay time. Only about $5 \%$ of the Rover fuel experienced the maximum case burnup of $0.1 \%$.

\subsection{Description of Rover Process/Facility}

The Rover process is based on three prime considerations: (1) primary and secondary burning of the fuel in fluidized bed burners to eliminate the graphite matrix and oxidize the uranium and niobium carbides, (2) separation of the heavy metal oxides produced in the burning stage from the inert alumina bed material prior to dissolution, and (3) dissolution of the uranium rich ash from the secondary burner to produce an aqueous solution containing the recoverable uranium. 
Table 1. Rover irradiated fuel description ${ }^{a}$

\begin{tabular}{|c|c|c|c|c|}
\hline Reactor & No. Elements & Total $\mathrm{U}(\mathrm{g})^{\mathrm{b}}$ & Composition & Form \\
\hline Kiwi A & 960 & 39,437 & Graphite-UC $\mathrm{UC}_{2}$ & Plates \\
\hline Kiwi $A^{\prime}$ & 792 & 21,503 & $\begin{array}{l}\text { Graphite- } \mathrm{UC}_{2} \\
\mathrm{NbC} \text { coated }\end{array}$ & $\begin{array}{l}\text { Cylindrical } \\
4 \text { hole elements }\end{array}$ \\
\hline Kiwi A3 & 792 & 20,586 & $\begin{array}{l}\text { Graphite- } \mathrm{UC}_{2} \\
\mathrm{NbC} \text { coated }\end{array}$ & $\begin{array}{l}\text { Cylindrical } \\
4 \text { hole elements }\end{array}$ \\
\hline Kiwi B1A & 1159 & 84,762 & $\begin{array}{l}\text { Graphite-UC } \\
\text { NbC coated }\end{array}$ & $\begin{array}{l}\text { Cylindrical } \\
7 \text { hole elements }\end{array}$ \\
\hline Kiwi B1B & 1147 & 85,893 & $\begin{array}{l}\text { Graphite- } \mathrm{UC}_{2} \\
\text { NbC coated }\end{array}$ & $\begin{array}{l}\text { Cylindrical } \\
7 \text { hole elements }\end{array}$ \\
\hline Kiwi B4A & 1542 & 190,614 & $\begin{array}{l}\text { Graphite-UC } \\
\text { NbC coated }\end{array}$ & $\begin{array}{l}\text { Hexagonal cross } \\
\text { section, } 19 \text { hole } \\
\text { elements }\end{array}$ \\
\hline Kiwi B4D & 1542 & 167,321 & $\begin{array}{l}\text { Graphite- } \mathrm{UC}_{2} \\
\mathrm{NbC} \text { coated }\end{array}$ & $\begin{array}{l}\text { Hexagonal cross } \\
\text { section, } 19 \text { hole } \\
\text { elements }\end{array}$ \\
\hline Kiwi B4E & 1542 & 180,801 & $\begin{array}{l}\text { Graphite- } \mathrm{UC}_{2} \\
\text { particles coated with } \\
\text { pyrolytic graphite } \mathrm{NbC} \\
\text { coated }\end{array}$ & $\begin{array}{l}\text { Hexagonal cross } \\
\text { section, } 19 \text { hole } \\
\text { elements }\end{array}$ \\
\hline NRX A2 & 1626 & 170,979 & $\begin{array}{l}\text { Graphite- } \mathrm{UC}_{2} \\
\text { particles coated with } \\
\text { pyrolytic graphite } \mathrm{NbC} \\
\text { coated }\end{array}$ & $\begin{array}{l}\text { Hexagonal cross } \\
\text { section, } 19 \text { hole } \\
\text { elements }\end{array}$ \\
\hline TNT & 1542 & 36,698 & $\begin{array}{l}\text { Graphite- } \mathrm{UC}_{2} \\
\text { particles coated with } \\
\text { pyrolytic graphite } \mathrm{NbC} \\
\text { coated }\end{array}$ & $\begin{array}{l}\text { Hexagonal cross } \\
\text { section, } 19 \text { hole } \\
\text { elements }\end{array}$ \\
\hline NRX A3 & 1626 & 170,978 & $\begin{array}{l}\text { Graphite- } \mathrm{UC}_{2} \\
\text { particles coated with } \\
\text { pyrolytic graphite } \mathrm{NbC} \\
\text { coated }\end{array}$ & $\begin{array}{l}\text { Hexagonal cross } \\
\text { section, } 19 \text { hole } \\
\text { elements }\end{array}$ \\
\hline Pheobus/A & 1478 & 185,105 & $\begin{array}{l}\text { Graphite- } \mathrm{UC}_{2} \\
\text { particles coated with } \\
\text { pyrolytic graphite } \mathrm{NbC} \\
\text { coated }\end{array}$ & $\begin{array}{l}\text { Hexagonal cross } \\
\text { section, } 19 \text { hole } \\
\text { elements }\end{array}$ \\
\hline NRX 4A & 1584 & 171,106 & $\begin{array}{l}\text { Graphite- } \mathrm{UC}_{2} \\
\text { particles coated with } \\
\text { pyrolytic graphite } \mathrm{NbC} \\
\text { coated }\end{array}$ & $\begin{array}{l}\text { Hexagonal cross } \\
\text { section, } 19 \text { hole } \\
\text { elements }\end{array}$ \\
\hline
\end{tabular}


Table 1. (continued).

\begin{tabular}{|c|c|c|c|c|}
\hline Reactor & No. Elements & Total $U(\mathrm{~g})^{\mathrm{b}}$ & Composition & Form \\
\hline NRX A.5 & 1584 & 169,493 & $\begin{array}{l}\text { Graphite- } \mathrm{UC}_{2} \\
\text { particles coated with } \\
\text { pyrolytic graphite } \mathrm{NbC} \\
\text { coated }\end{array}$ & $\begin{array}{l}\text { Hexagonal cross } \\
\text { section, } 19 \text { hole } \\
\text { elements }\end{array}$ \\
\hline Pheobus/B & 1506 & 179,714 & $\begin{array}{l}\text { Graphite- } \mathrm{UC}_{2} \\
\text { particles coated with } \\
\text { pyrolytic graphite } \mathrm{NbC} \\
\text { coated }\end{array}$ & $\begin{array}{l}\text { Hexagonal cross } \\
\text { section, } 19 \text { hole } \\
\text { elements }\end{array}$ \\
\hline NRX A6 & 1584 & 171,106 & $\begin{array}{l}\text { Graphite- } \mathrm{UC}_{2} \\
\text { particles coated with } \\
\text { pyrolytic graphite } \mathrm{NbC} \\
\text { coated }\end{array}$ & $\begin{array}{l}\text { Hexagonal cross } \\
\text { section, } 19 \text { hole } \\
\text { elements }\end{array}$ \\
\hline Pheobus 2A & 4068 & 296,550 & $\begin{array}{l}\text { Graphite- } \mathrm{JC}_{2} \\
\text { particles coated with } \\
\text { pyrolytic graphite } \mathrm{NbC} \\
\text { coated }\end{array}$ & $\begin{array}{l}\text { Hexagonal cross } \\
\text { section, } 19 \text { hole } \\
\text { elements }\end{array}$ \\
\hline Pewee 1 & 402 & 38,874 & $\begin{array}{l}\text { Graphite- } \mathrm{UC}_{2} \\
\text { particles coated with } \\
\text { pyrolytic graphite } \mathrm{NbC} \\
\text { coated } \\
\text { Some elements coated } \\
\text { with } \mathrm{ZrC}_{2}\end{array}$ & $\begin{array}{l}\text { Hexagonal cross } \\
\text { section, } 19 \text { hole } \\
\text { elements }\end{array}$ \\
\hline $\mathrm{XE} 1$ & 1584 & 171,089 & $\begin{array}{l}\text { Graphite- } \mathrm{UC}_{2} \\
\text { particles coated with } \\
\text { pyrolytic graphite } \mathrm{NbC} \\
\text { coated } \\
\text { Some elements coated } \\
\text { with } \mathrm{ZrC}_{2}\end{array}$ & $\begin{array}{l}\text { Hexagonal cross } \\
\text { section, } 19 \text { hole } \\
\text { elements }\end{array}$ \\
\hline NF 1 & 49 & 5,506 & $\begin{array}{l}\mathrm{UC}_{2}-\mathrm{ZrC}_{2} \text {-graphite } \\
\text { and }(\mathrm{U}-\mathrm{Zr}) \mathrm{C}_{2} \text { fuels } \\
\mathrm{ZrC}_{2} \text { coated }\end{array}$ & $\begin{array}{l}\text { The }(\mathrm{U}-\mathrm{Zr}) \mathrm{C} \text { elements } \\
\text { were much smaller of } \\
\text { hexagonal shape with } \\
\text { one hole }\end{array}$ \\
\hline UHTRE & 2664 & $\begin{array}{c}20,000 \\
93 \% \\
\text { Enrichment } \\
<0.1 \% \text { burnup }\end{array}$ & $\begin{array}{l}\text { Uranium carbide } \\
\text { dispersed in graphite } \\
\text { matrix }\end{array}$ & $\begin{array}{l}\text { Fuel rods are } 1 \text { in. } \\
\text { diameter } \times 6 \text { in. long }\end{array}$ \\
\hline
\end{tabular}

a. Rover Fuels Processing Facility, Final Safety Analysis Report, WIN-107-5.5, October 1983.

b. Before burnup, $93.15 \%$ of the uranium was ${ }^{235} \mathrm{U}$. 

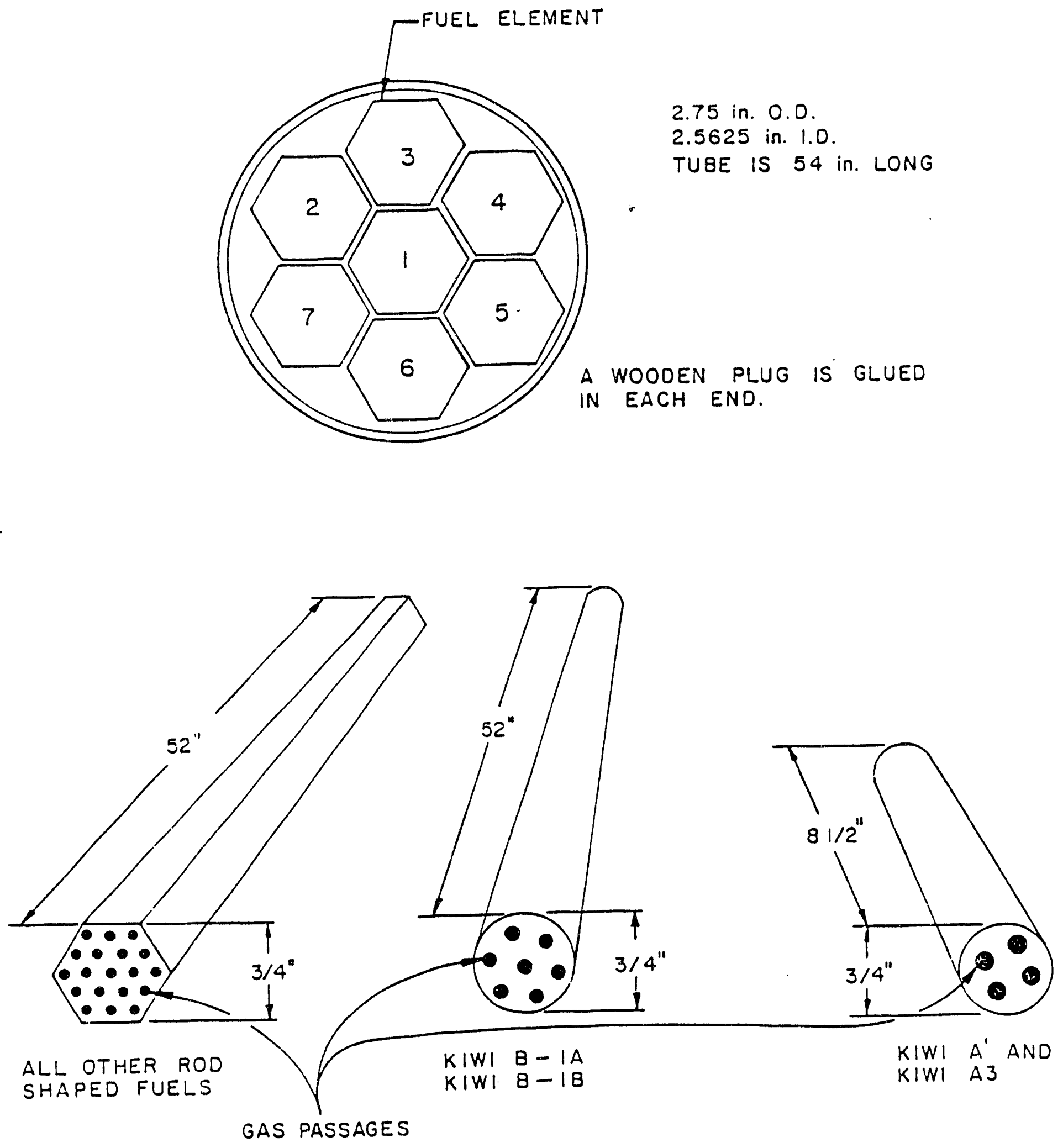

Figure 1. Fuel configuration in cardboard tubes and sketches of fuel shapes. 
Table 2. Rover fission product activities ${ }^{\mathrm{a}, \mathrm{b}}\left(\mathrm{Ci} / 24 \mathrm{~kg}\right.$ of original $\left.{ }^{235} \mathrm{U}\right){ }^{\mathrm{c}}$

\begin{tabular}{lccc}
\hline Nuclide & $\begin{array}{c}\text { Maximum case } \\
\text { (nuclear furnace) }^{\mathrm{d}}\end{array}$ & $\begin{array}{c}\text { Intermediate case } \\
(\text { NRX-A6) }\end{array}$ & $\begin{array}{c}\text { Average } \\
\text { case }^{\mathrm{f}}\end{array}$ \\
\hline${ }^{3} \mathrm{H}$ & $1.6 \mathrm{E}-1$ & $5.3 \mathrm{E}-2$ & $2.3 \mathrm{E}-2$ \\
${ }^{85} \mathrm{Kr}$ & $2.9 \mathrm{E}-1$ & $1.0 \mathrm{E}-1$ & $4.0 \mathrm{E}-2$ \\
${ }^{90} \mathrm{Sr}$ & 3.4 & 1.3 & $5.8 \mathrm{E}-1$ \\
${ }^{90} \mathrm{Y}$ & 3.4 & 1.3 & $5.8 \mathrm{E}-1$ \\
${ }^{99} \mathrm{Tc}$ & $6.0 \mathrm{E}-4$ & $2.5 \mathrm{E}-4$ & $1.1 \mathrm{E}-4$ \\
${ }^{106} \mathrm{Ru}$ & $1.0 \mathrm{E}-2$ & $1.9 \mathrm{E}-4$ & $8.9 \mathrm{E}-5$ \\
${ }^{106} \mathrm{Rh}$ & $1.0 \mathrm{E}-2$ & $1.9 \mathrm{E}-4$ & $8.9 \mathrm{E}-5$ \\
${ }^{121 \mathrm{~m}} \mathrm{Sn}$ & $3.1 \mathrm{E}-4$ & $1.2 \mathrm{E}-4$ & $5.2 \mathrm{E}-5$ \\
${ }^{125} \mathrm{Sb}$ & $2.0 \mathrm{E}-2$ & $2.1 \mathrm{E}-3$ & $8.9 \mathrm{E}-4$ \\
${ }^{125 m} \mathrm{Te}$ & $4.3 \mathrm{E}-3$ & $5.8 \mathrm{E}-4$ & $2.4 \mathrm{E}-4$ \\
${ }^{129} \mathrm{I}$ & $1.4 \mathrm{E}-5$ & $5.8 \mathrm{E}-6$ & $2.6 \mathrm{E}-6$ \\
${ }^{137} \mathrm{Cs}$ & 3.4 & 1.3 & $5.8 \mathrm{E}-1$ \\
${ }^{137 m} \mathrm{Ba}$ & 3.1 & 1.2 & $5.3 \mathrm{E}-1$ \\
${ }^{144} \mathrm{Ce}$ & $4.0 \mathrm{E}-2$ & $2.6 \mathrm{E}-4$ & $1.2 \mathrm{E}-4$ \\
${ }^{144} \mathrm{Pr}$ & $4.0 \mathrm{E}-2$ & $2.6 \mathrm{E}-4$ & $1.2 \mathrm{E}-4$ \\
${ }^{147} \mathrm{Pm}$ & 1.8 & $2.0 \mathrm{E}-1$ & $1.0 \mathrm{E}-1$ \\
${ }^{151} \mathrm{Sm}$ & $1.1 \mathrm{E}-1$ & $4.0 \mathrm{E}-2$ & $2.0 \mathrm{E}-2$ \\
${ }^{155} \mathrm{Eu}$ & $1.0 \mathrm{E}-2$ & $6.7 \mathrm{E}-4$ & $2.9 \mathrm{E}-4$ \\
${ }^{238} \mathrm{Pu}$ & $2.4 \mathrm{E}-5$ & - & - \\
${ }^{239} \mathrm{Pu}$ & $2.4 \mathrm{E}-3$ & - & - \\
${ }^{T 0 t a l}$ & 16 & 5.5 & 2.5
\end{tabular}

a. Rover Fuels Processing Facility Final Safety Analysis Report, WIN-107-5.5, October 1983.

b. Letter, D. R. Wenzel to D. E. Luke, "Rover Fuel Radiological Calculations," DRW-4-81, February 18, 1981, and letter, D. R. Wenzel to G. L. Borsheim, "Resolution of R\&ES-Related Comments on Rover Draft FSAR," WEN-06-83, March 10, 1983.

c. Maximum case decayed 9.5 years; intermediate and average cases decayed 14 years.

d. Nuclear furnace fuel with a burnup of $1,158 \mathrm{MW}-\mathrm{min} / \mathrm{kg}$ of original ${ }^{235} \mathrm{U}$.

e. NRX fuel with a burnup of $496.6 \mathrm{MW}-\mathrm{min} / \mathrm{kg}$ of original ${ }^{235} \mathrm{U}$.

f. Average case fuel with a burnup of $213 \mathrm{MW}-\mathrm{min} / \mathrm{kg}$ of original ${ }^{235} \mathrm{U}$. 


\subsubsection{Mechanical Handling Cave}

The mechanical handling cave is located in the process make-up area CPP-640. The mechanical handling cave and its equipment provide the system for unloading the fuel from the transfer casks and charging of the cardboard tubes to the primary burner. The Rover-burner charging system consists of a 4-in. swing-tube arrangement in which the 2.75 in. diameter cardboard tubes are placed. Ash collection and transfer, filtration of vessel offgas, and storage of burner bed material also take place in the mechanical handling cave. Figure 2 provides a three-dimensional view of the Rover facility.

\subsubsection{Primary Burning}

The primary burner is a two-stage concentric fluidized bed burner that is 16 -in. internal diameter, $15 \mathrm{ft} 1 / 2 \mathrm{in}$. high. The bottom, or first stage, is where the whole fuel rod is initially burned, and the top, or second stage, provides additional residence time for combustion of unburned carbon leaving the first stage. The concentric tluidized beds of alumina $\left(\mathrm{Al}_{2} \mathrm{O}_{3}\right)$ allow for rapid heat transfer from the highly exothermic combustion reaction. Graphite fines and uranium/niobium ash generated in the primary burning are elutriated out of the burner and collected on sintered metal filters in the primary collection pot. The primary burner ash is then the feed for the secondary burner. The primary burner is operated on a continuous basis, and the secondary burner is operated on a batch basis. Primary burning is $\sim 65 \%$ efficient in converting the carbon to oxide form.

\subsubsection{Secondary Burning}

Secondary burning further reduces the carbon content of the primary burner ash to less than $2 \%$ by weight before feeding the ash into the wet system (i.e., the dissolver and complexer). The secondary burner is also a fluidized bed burner utilizing $\mathrm{Al}_{2} \mathrm{O}_{3}$ as the bed material. Sintered metal filters in the top of the secondary burner retain the fines in the burner promoting complete combustion of the combustible fraction. Once combustion of the carbon is complete, the fluidizing gas velocity increases to elutriate the ash out of the burner and collects in the secondary collection pot. The burner is then cooled and prepared for another batch of primary burner ash.

\subsubsection{Offgas}

The primary and secondary burner products of combustion are $\mathrm{CO}, \mathrm{CO}_{2}, \mathrm{U}_{3} \mathrm{O}_{8}, \mathrm{Nb}_{2} \mathrm{O}_{5}$, and $\mathrm{Nb}_{3} \mathrm{UO}_{10}$. The uranium and niobium oxides are retained in the system by sintered metal filters. The carbon dioxide/monoxide, volatile and semivolatile radionuclides that passed through the sintered metal filters are subsequently processed through high efficiency particulate air (HEPA) filters. Gaseous fission products and $\mathrm{CO} / \mathrm{CO}_{2}$ pass through the HEPA filters before entering the main ICPP Atmospheric Protection System (APS). The APS system handles all the processing and cell ventilation air flows throughout the ICPP site. Before discharge from the 76-m high stack, the offgas is passed through a deep-bed fiberglass prefilter and a bank of HEPA filters.

Dissolver offgas is vented to the dissolver offgas system in CPP-601, where hydrotluoric acid (HF) vapors are removed before entering the main plant demister, super heater, and HEPA system. 


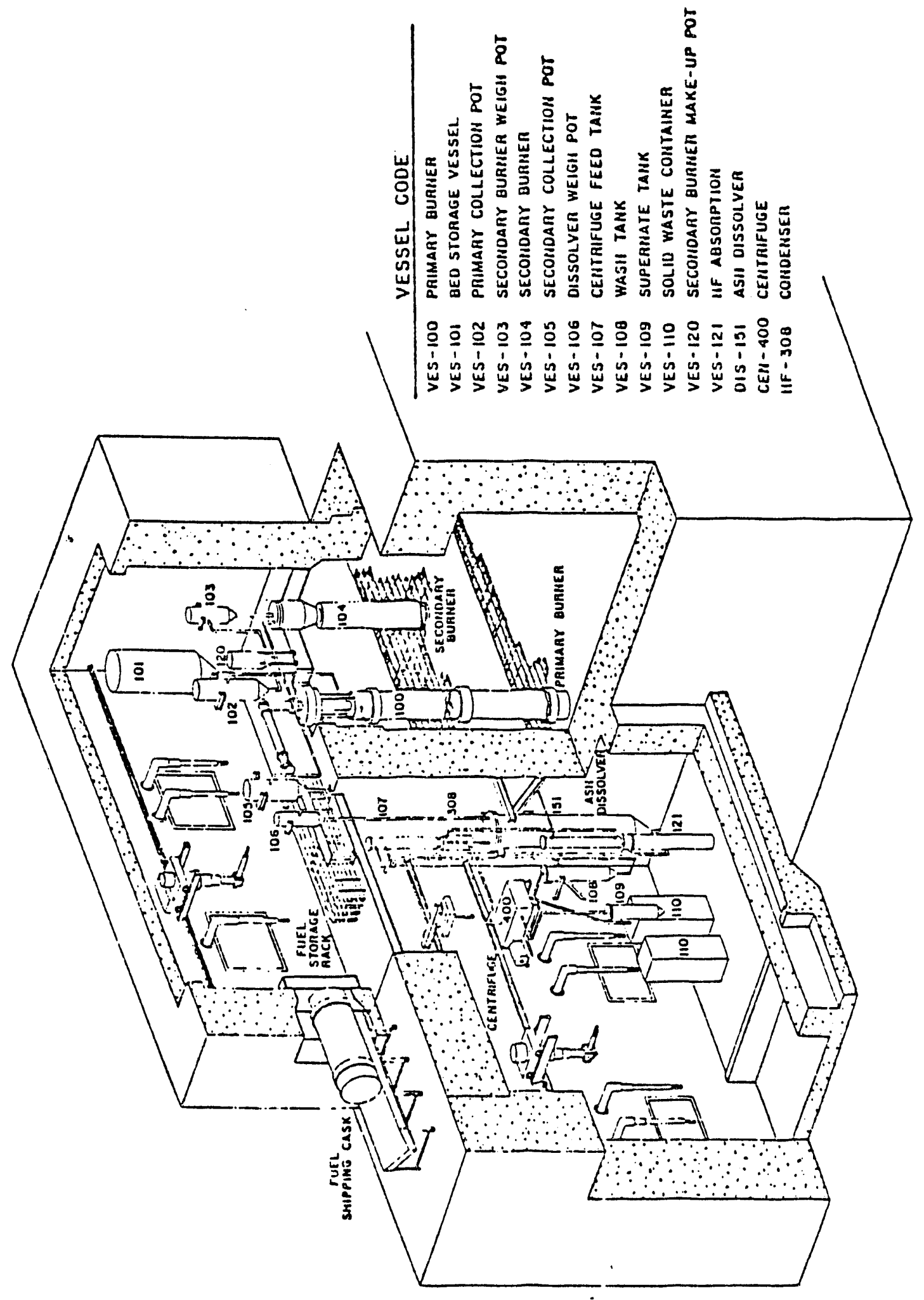

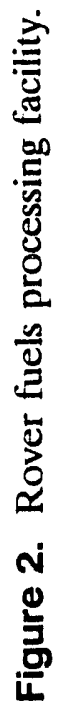




\subsubsection{Dissolver}

The dissolver dissolves greater than $99.9 \%$ of the uranium and niobium contained in the burner ash. The ash is first contacted with nitric acid and then hydrofluoric acid. The hydrofluoric acid is necessary to dissolve the $\mathrm{Nb}_{3} \mathrm{UO}_{10}$. Upon completion of the dissolution, the solution was transferred to a complexing tank where aluminum nitrate is added to complex the free fluoride and protect the stainless steel equipment downstream. At this point, the complexed dissolver solution is processed through existing ICPP solvent-extraction equipment to recover the uranium. A simplified Rover processing system flow diagram is shown in Figure 3. 


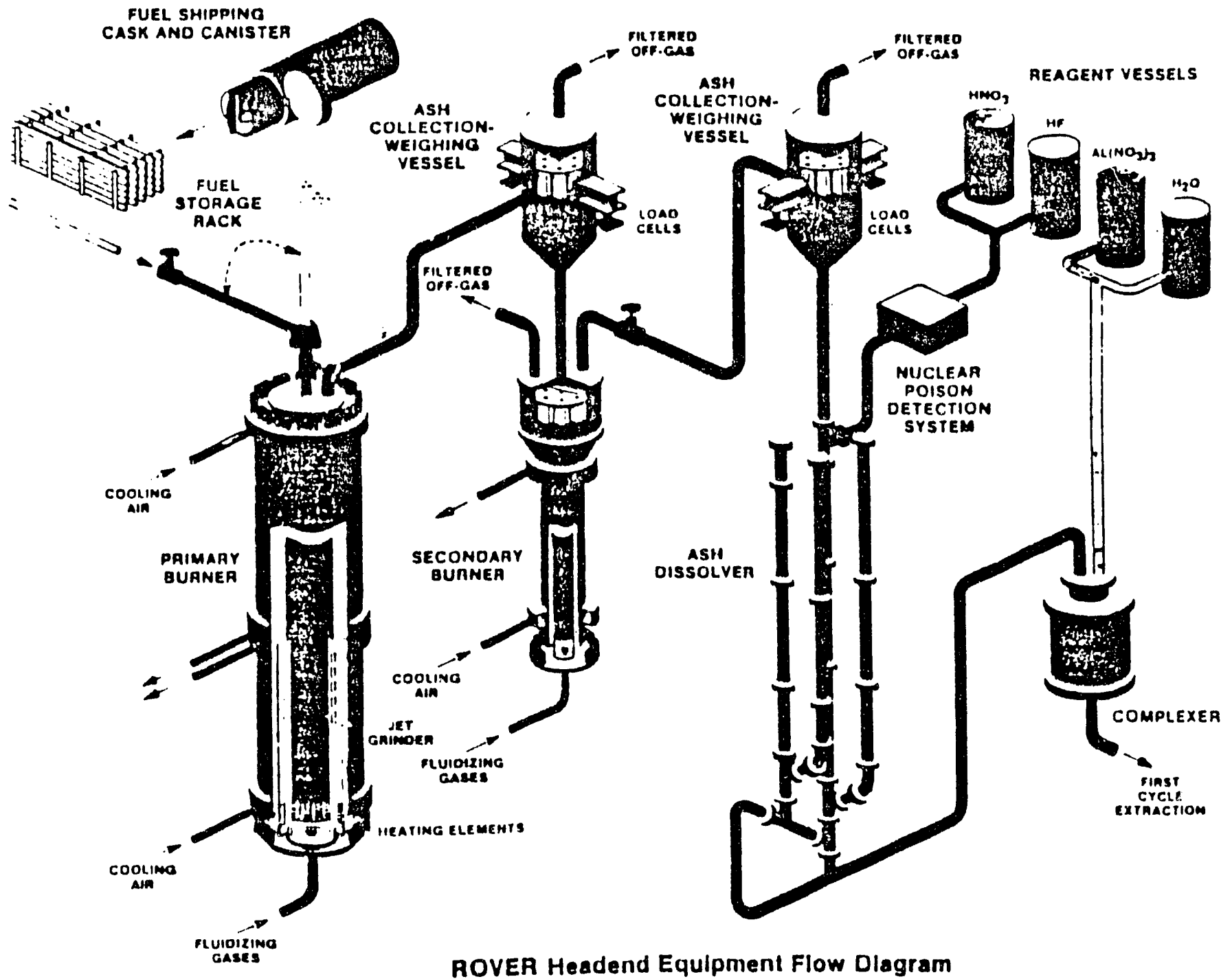

Figure 3. Rover processing system. 


\section{ROVER PROCESS AND FACILITY STATUS}

\subsection{Condition of Existing Equipment/Facility}

After shutdown of the Rover operations in June 1984, the lacility was placed in a stand-by state of monitoring and maintenance awaiting decisions on dispositioning of the remaining bed and ash material and equipment. The uranium remaining within the system must be recovered to satisfy accountability needs and criticality potential concerns. As a part of the shutdown operation, the wet system was isolated from the dry system, and steps were taken to prevent any intrusion of moderator material into the processing cells. The product transfer line between the dissolver weigh pot and dissolver was separated and a blind flange installed that effectively isolated the wet and dry system equipment. The wet system was then decontaminated by flushing with borated water followed by a heelout of nitric and hydrofluoric acid. The decontamination of the wet system vessels was carried out until the heelout solution yielded $0.035 \mathrm{~g}$ of uranium per liter ( $\mathrm{U} / \mathrm{L}$ ) and no uranium bearing solids. ${ }^{a}$ The process make-up lines and utility lines entering the Rover cells were cut and capped to prevent any possible intrusion of moderator materials. All Rover process instrumentation not required to monitor and maintain the system in a safe shutdown configuration were taken out of service. Five group 1 instruments, monitoring cell 3 sump level, criticality alarms in cell 2 , and process makeup areas, and 2 group II instruments, monitoring differential pressure across four filter plenums, remained in service. ${ }^{a}$ All personnel and material accesses (except for two) were modified to prevent entry.

In 1988 an effort to determine an approach to decommissioning the Rover equipment and recovering the accountable material remaining in the dry system was conducted. ${ }^{b}$ This effort evaluated the status of the Rover equipment and factors supporting and opposing the potential reuse of the Rover facility. As a result of the investigation and reviews conducted by the technical and operational personnel involved in the Rover fuels processing program. Westinghouse Idaho Nuclear Company (WINCO), operator of the Rover facility, took the position that the Rover system was not reusable and should be decontaminated and decommissioned. Potential methodologies for removal of the bed and ash material were identified and issues that needed to be resolved were detailed. Additional investigation into the areas of concern with the Rover system as it is now configured verifies the WINCO position.

\subsubsection{Head-End Dry System}

The head-end dry system components consist of the mechanical handling equipment, feed charge equipment, primary and secondary burners, bed storage vessels, and ash collection vessels. Factors opposing the reuse of the Rover dry system as identified in the 1988 effort and subsequent information obtained through telephone interviews with experts knowledgeable on the Rover Process are discussed below.

a. Draft letter from W. C. Moffitt to A. A. Pitrolo, "Rover Facility-Status of PSD, Section 5.5," Westinghouse Idaho Nuclear Company Inc., WCM-xxx-92, December 1, 1992.

b. Letter to S. M. Halupa from L. T. Cole, "Recommendations for Rover Uranium Recovery and System Disposition," Westinghouse Idaho Nuclear Company, Inc., LTC-2-88, February 1988. 
1. The burner vessels may not meet all the criticality safety requirements of current U.S. Department of Energy (DOE) Orders. ${ }^{9-12}$ The burner vessels were not designed to be critically safe by geometry and placed a heavy reliance on administrative controls to ensure criticality safety. Both the primary and secondary burner vessels require active engineering and administrative controls to ensure that moderating moisture is excluded. Even if moisture is excluded, the disengaging head of the secondary burner is not critically safe by geometry and depends on administrative controls to a degree that may not be acceptable under current safety standards. Further, the calculations of $\mathrm{K}_{\text {eff }}$ used in the safety analysis of the Rover facility ${ }^{1}$ may underestimate the criticality potential of the disengaging head because they do not follow current practice of assuming completely reflective conditions. A reassessment of potential criticality issues would be required if the Rover facility were to be considered for restart.

2. Accountability needs may require disassembly of the burner system to recover all the special nuclear material remaining in the system. Two primary options for removal of the remaining bed and ash material are (1) restarting the dry system equipment to fluidize and removing the bed material or (2) cutting apart the vessels for access and removing the bed material. Restarting the dry side equipment may be restricted because of the scavenging of equipment, operational instrumentation, and cutting and capping of the utility lines. Additionally, plugging of the processing lines and the primary collection vessel is highly likely due to ash and alumina fines being solidified by aluminum metal left in the fuel assemblies processed near the end of the Rover campaign. Destructive cutting and special tools may be required to remove some of the material left in place. Table 3 shows the estimated quantities of uranium and alumina bed-material in the Rover process vessels and surface contact radiation readings.

3. The pneumatic instrumentation design is deficient and has resulted in personnel contamination and radiation exposure. The instrumentation lines operate at a positive pressure in relation to the operating corridors; thus, a potential exists for release and contamination of these operating areas.

Table 3. Remaining uranium assessment.

\begin{tabular}{ll}
\hline VES-100 (Primary burner) & $600 \mathrm{~kg}$ alumina, $34 \mathrm{~kg} \mathrm{U}$ \\
& $3-5 \mathrm{R} / \mathrm{h}^{\mathrm{a}}$ \\
VES-104 (Secondary burner) & $75 \mathrm{~kg}$ alumina, $12 \mathrm{~kg} \mathrm{U}$ \\
& $3-5 \mathrm{R} / \mathrm{h}$ \\
VES-102 (Primary ash collection pot) & $80 \mathrm{~kg}$ alumina, $40 \mathrm{~kg} \mathrm{U}$ \\
& $50 \mathrm{R} / \mathrm{h}$ \\
F-116 (HEPA filter) & Unknown alumina and U \\
& $2.5 \mathrm{R} / \mathrm{h}$ \\
Remaining vessels and piping & Unknown alumina and U
\end{tabular}

a. Alumina and $U$ numbers, which are best available, are not exact. 
4. The system is not designed for remote maintenance, which is desirable for radiation and contamination exposure control. Multiple skin contamination incidents occurred during in-cell hands-on work while processing in 1983 and 1984. Additionally, radiation tields associated with higher burn-up fuels (e.g., FSV fuel) will greatly exceed those which existed during processing of Rover fuel. Contact maintenance would not be feasible under these conditions.

5. Considerable system refurbishment and inspection is required that will result in significant radiation exposure and contamination risk to operators. The poison monitoring system has been scavenged, and most safety class operational instrumentation has been taken out of service except for those instruments required for maintaining a safe shutdown condition (e.g., pressure sensors across filters and radiation detection instruments).

6. Unknown system effects caused by foreign or uncharacterized substances in the fuel (e.g., $\mathrm{Al}$ powder, $\mathrm{Si}, \mathrm{ZrC}_{2}$ ) may be present. The effect of these unknowns will be difficult to predict and correct before restart and checkout.

7. The design life of the Rover hardware was only for the short time that fuel was processed. Therefore, equipment reliability for any significant processing campaign must be evaluated.

8. The feasibility of processing similar graphite-based fuels in storage in the existing Rover system is diminishing over time as past operational experience and familiarity with the system is lost.

9. The formal position taken by Westinghouse is stated in the following: ${ }^{c}$

The Rover Facility in CPP-640 was shut down at completion of the Rover campaign in 1984. The system's current condition makes it inoperable. The dry part of the system is substantially plugged, has high radiation fields, is contaminated, and numerous components have failed. The Rover system was designed to operate with a life span sufficient only to complete the processing of the original Rover fuels. A complete inspection and repair program would entail excessive exposure and contamination risk. Additionally, the contamination control system utilized in the Rover process is inadequate by today's standards. It is doubtful that the Rover process system as now configured could be operated without significant contamination incidents.

\subsubsection{Wet System}

The dissolver, complexer, centrifuge, and associated equipment comprise the Rover wet system. The solvent extraction equipment required for uranium recovery is part of the main ICPP plant located in the adjacent processing facility (CPP-601). ${ }^{1}$ The Rover wet system was considered to be

c. Letter to J. P. Hamric from E. W. Pottmeyer regarding Rover system's current condition, 1987. 
in good condition at time of shutdown with minor problems such as leaky valves. The wet system was decontaminated by flushing with borated water and nitric/hydrofluoric acid until the resulting heelout solution yielded $0.035 \mathrm{~g} \mathrm{U} / \mathrm{L}$ and no uranium solids residue. The cutting and capping of process lines from the process make-up area will impact the restart of the wet system.

Criticality safety of the we system was designed to depend on administrative controls and active engineering in the form of neutron-absorbing boron incorporated in the process materials. This was required because, while the Rover dissolver is critically safe by geometry, vessels downstream of the dissolver are not. ${ }^{1}$ These vessels are the dissolver surge tank, complexer, and Rover centrifuge system including the supernate collection tank. ${ }^{1}$ A complex set of procedures and process limitations is required to ensure that critically safe combinations of neutron poison, moderator, and uranium are maintained in the wet system. These controls depended on the reliable operation of the neutron poison monitoring systenı. This system has been scavenged and would need to be replaced if the existing wet system were to be used. ${ }^{b}$ Even if the original Rover wet system were to be refurbished, it is not clear wheiher this reliance on active engineering and administrative controls would meet the requirements of the current DOE Order for criticality safety. A complete reassessment would be necessary.

\subsubsection{Offgas System}

The primary and secondary bu ner ash was retained in the primary and secondary collection pots, respectively, by sintered metal filters. The offgas passing through the sintered metal filters was combined with the various cell ventilation air flows and passed through local HEPA filters and into the ICPP APS. Plant air emissions are additionally exhausted through fiberglass prefilters and HEPA filters before being discharged to the atmosphere through the $250 \mathrm{ft}$ high stack.

The very low burnup of the Rover fuel resulted in very low fission product inventories as provided in Table 2. The dilution effect of combining the burner offgas with other plant exhaust streams decreased the radionuclide concentrations significantly before release and dispersion into the atmosphere. Small amounts of the gaseous radionuclides were exhausted to the environment.

\subsubsection{Facility Status}

The Rover system is located in building CPP-640, which was formally the Hot Pilot Plant facility. It is located next to the processing building CPP-601. CPP-640 contains five heavily shielded cells, four of which were used for the Rover process equipment, and the mechanical handling cave. Three levels, one abovegrade, one at grade, and one belowgrade, make up CPP-640. Cell floors, walls, and ceilings are constructed of high-density and ordinary reinforced concrete 2 to $4 \frac{1}{2} \mathrm{ft}$ thick.

The facility's structural and mechanical safety must be evaluated against today's standards before initiation of any new or modified processing operations. DOE Order 6430.1A, "General Design Criteria," provides mandatory, minimally accepted requirements for lacility design. Facility use and activity hazard classification will dictate the level of evaluation required to meet DOE Order 6430.1A standards. Extensive evaluation at consideralle cost is required for moderate and high hazard class activities. It is likely that the Rover facility and processes will be classified as a moderate hazard activity and may potentially be a high hazard activity. 


\subsection{Chemical and Physical Effectiveness of the Rover Process}

The chemical processes within the system occur primarily in two ways: (1) the combustion reactions of the carbon, uranium, niobium, and fission products to their oxidized states and chemical acid leaching and (2) complexing reactions of the uranium/niobium oxides into their corresponding species in an aqueous solution. The effectiveness of these processes have been proven to recover $99 \%$ of the uranium from Rover-type graphite fuels. ${ }^{2-6}$ Uranium recovery effectiveness was the primary focus of the studies that were performed by ORNL in first evaluating options for processing Rover fuels. Several alternatives were evaluated before concluding that the burn-leach technology was the preferred method that had been successfully demonstrated on an operational scale by the Rover processing campaign.

\subsection{Safety Concerns}

\subsubsection{Criticality}

The current version of DOE Order 5480.24 "Nuclear Criticality Safety," requires that geometry control shall be the preferred method of ensuring criticality safety. It states explicitly that the DOE requires this, and the referenced ANSI standard ${ }^{13}$ (ANS-8.1) merely recommends it. The DOE Order states that "as a first priority, reliance shall be placed on equipment design... . Where geometry control is not feasible, the preferred order of controls is other passive controls, active engineering controls, and administrative controls." 9

The Rover fuel processing facility does not meet these requirements. It is designed so that some vessels of both the dry and wet systems are not critically safe by geometry. Exclusion of moderating moisture was the primary basis for criticality control of the dry system. A complex set of procedures and process limitations is required to ensure that critically safe combinations of neutron poison, moderator, and uranium are maintained in the wet system. No other passive engineering controls were explicitly included in the design. These systems depended on active engineering and administrative controls to a degree that may not be acceptable under current DOE safety standards.

\subsubsection{Operational}

Operational safety considerations for restart of the Rover facility include radiation protection and contamination control. Decontaminating and restarting the Rover system would require in-cell, hands-on work by personnel in radiation fields associated with the existing Rover system. These fields are as high as $50 \mathrm{R} / \mathrm{h}$ at the primary ash collection pot (see Table 3 ).

The radiation fields associated with the existing Rover system result from the presence of fission products in amounts characteristic of the low burn-up Rover fuel. The FSV fuel has a burn-up of as high as $50 \%$ and a resulting fission product inventory 100 to 1000 times higher than the Rover fuel for comparable amounts of remaining uranium (see Section 3 ). If the radiation fields listed in Table 3 were to scale with the fission product inventory, they would indicate the potential for radiation fields of up to $50,00 \mathrm{R} / \mathrm{h}$ during processing of FSV fuel. The contamination control problems experienced during processing operations in 1983 and 1984 would have the potential to scale by similar factors. 
The Rover system was not designed for the remote maintenance requirements of radiation fields of this magnitude. Significant upgrades to radiation shielding, access control, contamination control, and maintenance systems would be required to accommodate FSV fuel in the Rover facility. 


\section{CHARACTERIZATION OF FORT ST. VRAIN FUEL}

\subsection{Physical Characteristics}

Three types of fuel elements make up the core in the FSV reactor: ${ }^{8}$ standard, control, and bottom control. There are 1.260 standard fuel elements, 185 control fuel elements, and 37 bottom control fuel elements, bringing the total to 1,482 fuel elements in the FSV core. All the fuel elements are hexagonal blocks of nuclear grade graphite 14.172 in. across flats, 8.182 in. per side, and $31.2 \mathrm{in}$. long. The differences between the fuel elements is in the number of fuel, coolant, and control rod holes per block. Standard fuel elements contain the most fuel in 210 1/2-in. diameter holes extending most of the way through the block. Two sizes of fuel rods were used in the FSV fuel: 0.5 in. diameter $\times 3$ in. long and 0.5 in. diameter $\times 2$ in. long. When fully loaded, a standard FSV fuel element contained 3,132 (2-in.) fuel rods or 2,088 (3-in.) fuel rods. Standard fuel elements contain 108 coolant holes, six burnable poison holes, and a fuel handling pickup hole as illustrated in Figure 4. The control fuel elements each have 120 fuel holes, 57 coolant holes, two (4 in. diameter) control rod channels, and one (3.75 in. diameter) reserve shutdown control rod channel. The control fuel elements contain 1,782 (2-in.) fuel rods, and the bottom control fuel elements contain 1,302 (2-in.) fuel rods (see Figures 5 and 6).

The fuel kernels are divided into a fissile fraction and fertile fraction. Both the fissile and fertile kernels are TRISO-coated microspheres. The fissile fuel is a uranium carbide $\left(\mathrm{UC}_{2}\right)$, and the fertile fuel is a uranium and thorium carbide $(\mathrm{U} / \mathrm{Th}) \mathrm{C}_{2}$. The inner fuel particle is coated with a low-density $\mathrm{PyC}$, high-density $\mathrm{PyC}$, silicon carbide ( $\mathrm{SiC}$ ) coating, and outer high-density $\mathrm{PyC}$ (see Figure 7). The fuel kernels were originally designed to be recycled; therefore, the fissile and fertile particles are of different sizes for classification purposes. The approximate outside diameters of the fertile and fissile particles are $730 \mu$ and $460 \mu$, respectively. The fuel element weights per component are listed in Table $4 .^{8}$

\subsection{Chemical Composition}

Nuclear grade graphite is generally high-quality needle coke graphite with small crystallites and low impurity levels. The FSV graphite blocks are either type H-327 or H-451 graphite. The fuel rods are bonded in a low-density graphite matrix. Both the graphite block and fuel rod graphite have low levels of impurities. Specific manufacturing limits on concentrations are listed in Table 5. Two primary impurities of concern from the post irradiation standpoint are nitrogen and lithium. The nitrogen impurity is neutron activated to form ${ }^{14} \mathrm{C}$, and the lithium is activated to form tritium $\left({ }^{3} \mathrm{H}\right)$. As noted in Table 5, neither the nitrogen nor lithium concentration limit is specified. Literature information indicates that nitrogen concentrations may range from 0 to $100 \mathrm{ppm}$ in graphite with a typically used value of 26 ppm. ${ }^{14-16}$ Some measured values have been at $10 \mathrm{ppm}$ that result in lower predicted concentrations of ${ }^{14} \mathrm{C}$. For the purposes of this study, the $26 \mathrm{ppm}$ will be used. For lithium, a typical value of only $0.005 \mathrm{ppm}$ has been used. 

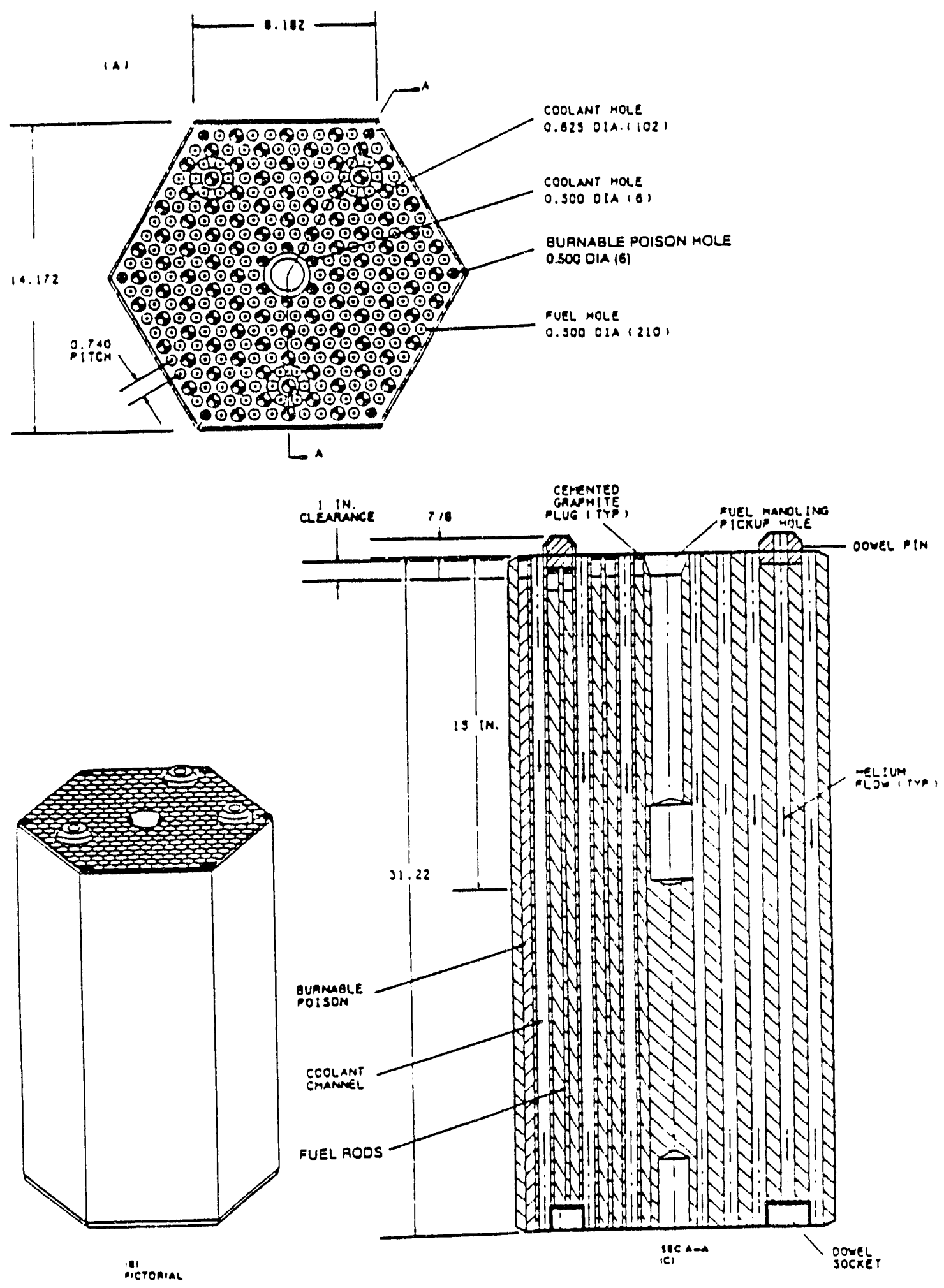

Figure 4. FSV standard fuel element. 

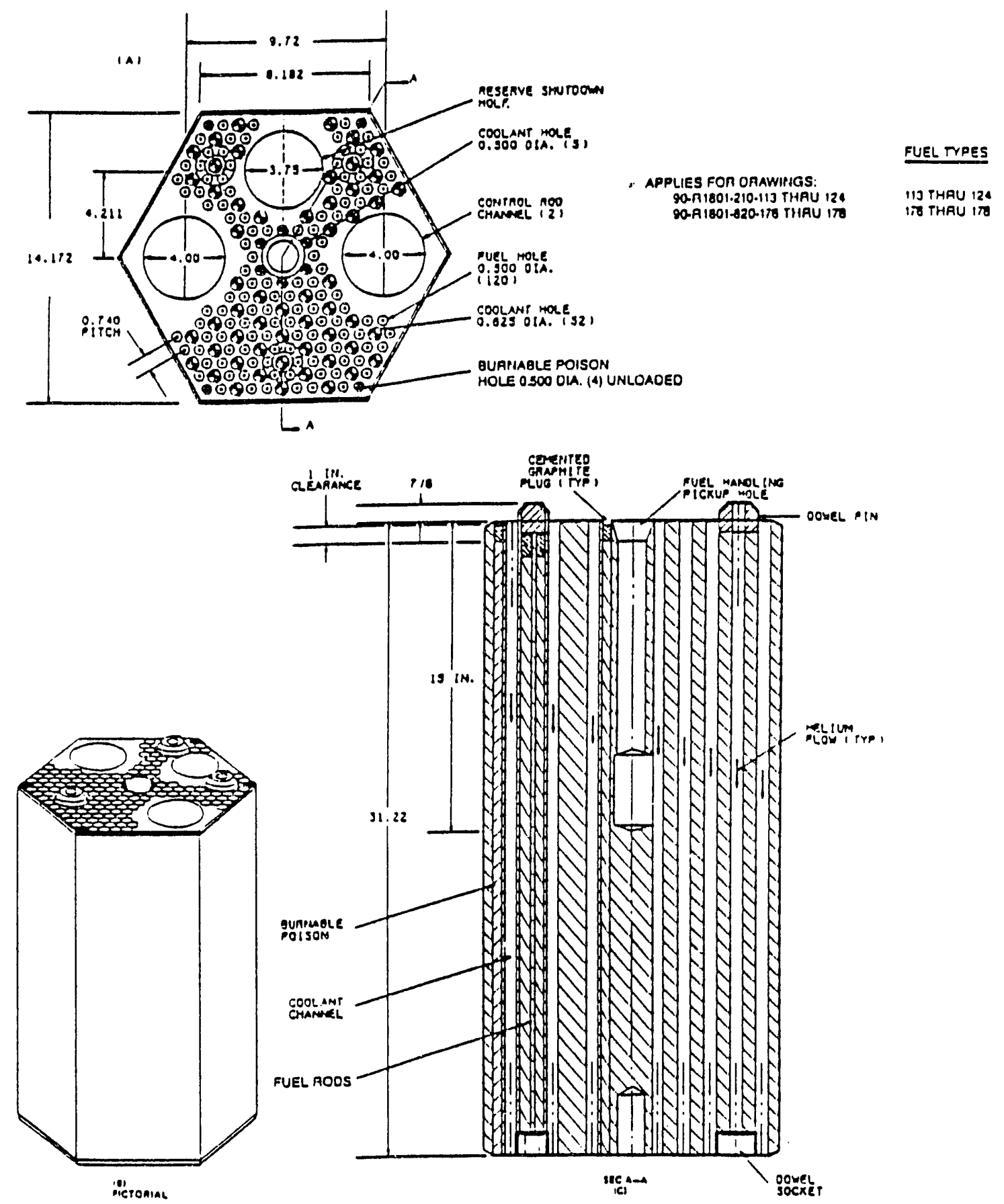

Figure 5. Control fuel elements and surveillance control element. 

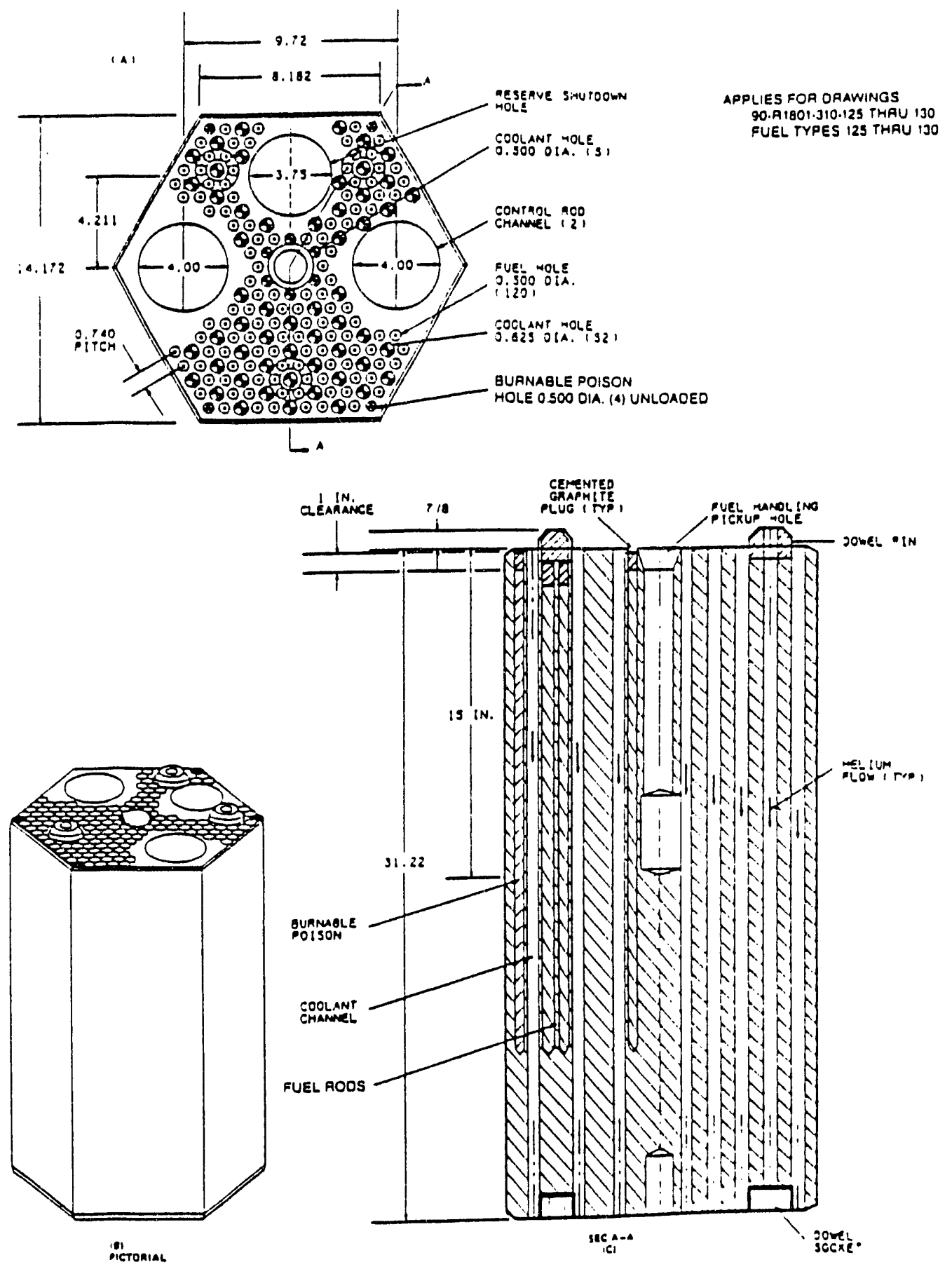

Figure 6. Bottom control fucl element. 


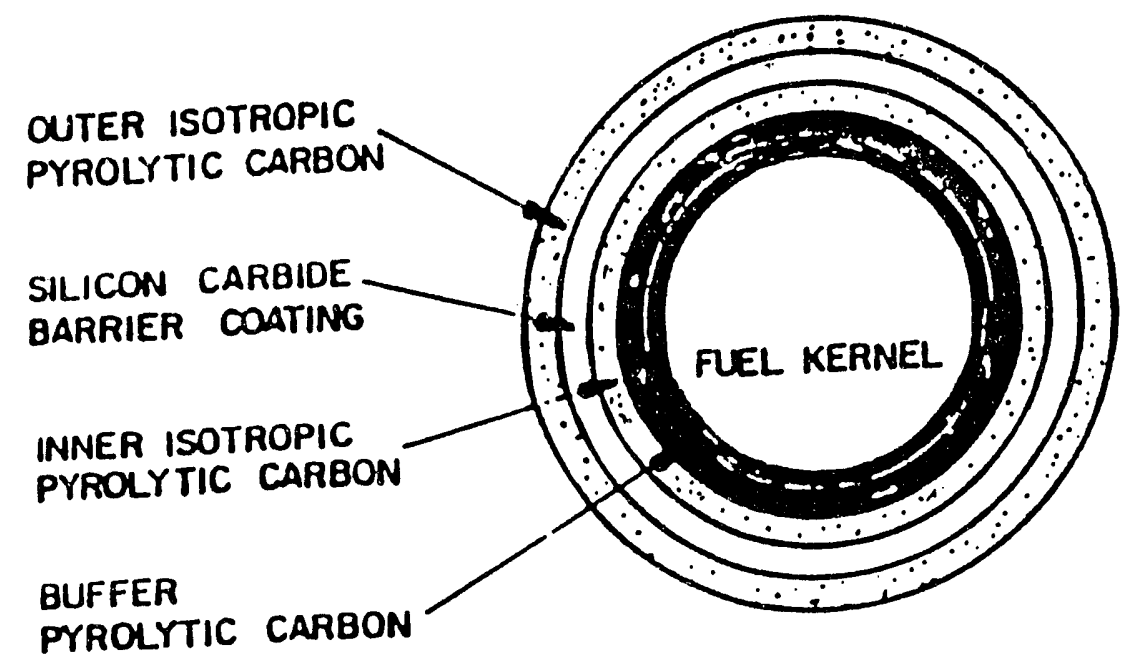

Figure 7. TRISO fuel kernel. 


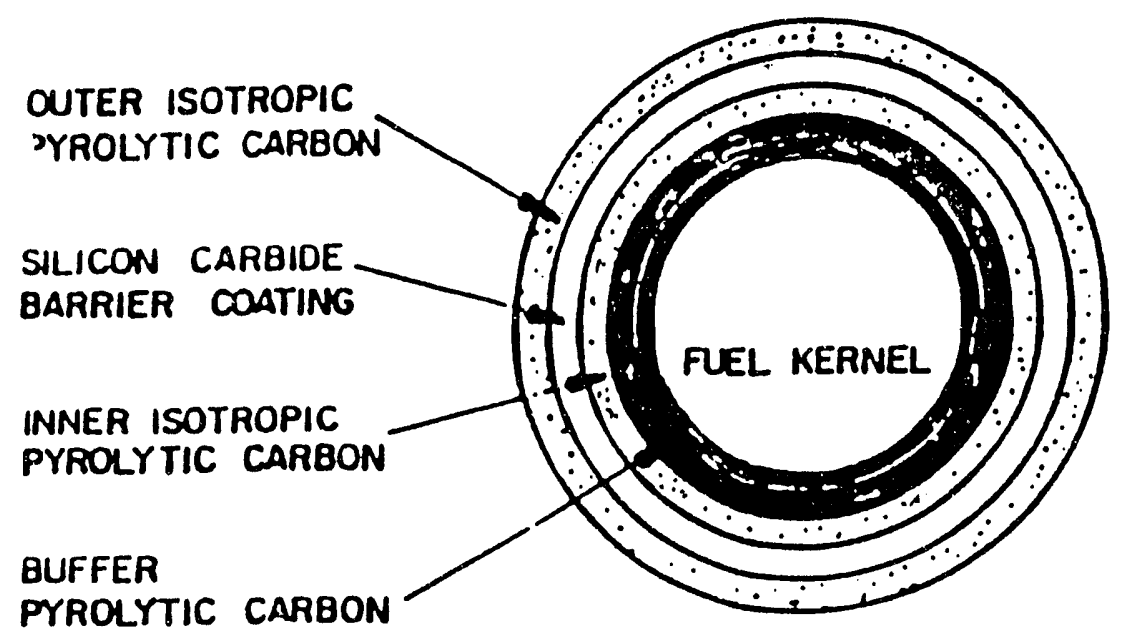

Figure 7. TRISO fuel kernel. 
Table 5. Impurity level specifications. ${ }^{a}$

\section{Property}

Maximum acceptable value

(ppm)

Fuel Block

Boron

Iron

100

Titanium and vanadium

100

Nitrogen (not specified)

\section{Fuel Rod}

Total boron equivalents of impurities in fired fuel rods

For any fuel rod lot:

Total burnable ${ }^{b}$ 10

Total nonburnable ${ }^{c}$

For any fuel element:

Total burnable ${ }^{b}$

Total nonburnable ${ }^{c}$

2

Other impurities ${ }^{d}$

Sulfur

Hydrogen (residual after firing)

Residual chlorine

Iron (segment weighted average)

Transition metals (each metal) ${ }^{e}$

a. U.S. Department of Energy, DOE Characteristics of Potential Repository Waste, Vol. 2, DOE/RW-0184-R1.

b. The total burnable value is the total boron equivalent content of $\mathrm{B}, \mathrm{Cd}, \mathrm{Eu}, \mathrm{Gd}$, and $\mathrm{Sm}$.

c. The total nonburnable value is the total boron equivalent content of $\mathrm{Al}, \mathrm{Ag}, \mathrm{Ba}, \mathrm{Bi}, \mathrm{Ca}, \mathrm{Cr}, \mathrm{Co}, \mathrm{Cu}, \mathrm{Fe}$, $\mathrm{Mg}, \mathrm{Mn}, \mathrm{Mo}, \mathrm{Ni}, \mathrm{P}, \mathrm{Na}, \mathrm{Sr}, \mathrm{S}, \mathrm{Sn}, \mathrm{Ti}, \mathrm{V}$, and $\mathrm{Zn}$.

d. These are maximum values for any fuel rod lot and are given in terms of mass of impurity, not boron equivalents.

e. The transition elements referred to are $\mathrm{Co}, \mathrm{Cr}, \mathrm{Mn}_{\mathrm{v}}$ and $\mathrm{Ni}$. The limit of $55 \mathrm{ppm}$ (mass) applies to each element. 


\subsection{Radiological Composition}

Radionuclide inventories within the graphite depend on

1. Concentration of impurities within the graphite

2. Neutron flux levels in the graphite

3. The specific nuclide neutron cross-sections

4. The production and decay routes of isotopes

5. Percent of fuel particle breakage/fission product release

6. Extrapolation or integration of point calculations over the whole core region.

The primary radionuclides that exist in the irradiated graphite core material, barring any fuel or fission product release from the coated fuel kernels, are the result of neutron activation of impurities within the graphite. One of the more abundant radionuclides, ${ }^{14} \mathrm{C}$, is produced from the neutron activation of ${ }^{14} \mathrm{~N}(n, p)$ and ${ }^{13} \mathrm{C}\left(\mathrm{n}\right.$,gamma). It has been estimated that $75 \%$ of the ${ }^{14} \mathrm{C}$ that results is produced from the activation of the ${ }^{14} \mathrm{~N}$ impurity. As mentioned above, the nitrogen impurity level typically used to evaluate ${ }^{14} \mathrm{C}$ concentration is $26 \mathrm{ppm}$.

The actinides and fission product inventories within the FSV fuel kernels are based on the initial heavy metal (IHM) loading and percent burnup the fuel has experienced. The equilibrium core burnup for the FSV fuel, as designed, was $100,000 \mathrm{MWd}$ /metric ton of initial heavy metal (MTIHM). The equilibrium core would be reached in 6 years if refueling occurs once a year with approximately one sixth of the core being replaced per refueling. Therefore, the longest irradiation time any fuel element would experience is 6 years, and the shortest time is 1 year.

Radiological characterization of the FSV fuel has been conducted using the above data and reactor parameters and a computer software program known as the ORIGEN isotope generation and decay code. ${ }^{17}$ The ORIGEN code calculates the isotope inventories of more than 700 isotopes in the fuel as a function of the length of irradiation and post-irradiation decay time. Table 6 provides a summary of the ORIGEN code computed radionuclide activities in curies per MTIHM for 10 year cooling time (column 2). Additionally, since none of the FSV fuel has experienced equilibrium burnup of $100,000 \mathrm{MWd} / \mathrm{MTIHM}$, a column is included in Table 6 representing the estimated isotope inventory for $47,000 \mathrm{MWd} / \mathrm{MTIHM}$ or approximately $50 \%$ burnup. ${ }^{8}$ The estimated values for radionuclide inventories in fuel experiencing lower burnup were determined using simple linear interpolation from the valves at $100,000 \mathrm{MWd} / \mathrm{MTIHM}$ (as suggested in DOE RW-0184-R1) ${ }^{8}$ as a tirst approximation. Linear interpolation of valves on the transuranic content of the fuel at lower burnups will give conservative results. 
Table 6. Fort St. Vrain fuel radionuclide inventory (Ci/MTIHM).

\begin{tabular}{|c|c|c|}
\hline Nuclide & 10-year cooling time & 10 -year cooling time and $50 \%$ burnup \\
\hline \multicolumn{3}{|l|}{ Fission Products } \\
\hline${ }^{85} \mathrm{Kr}$ & $2.715 E+04$ & $1.358 \mathrm{E}+04$ \\
\hline${ }^{90} \mathrm{Sr}$ & $2.220 \mathrm{E}+0.5$ & $1.110 \mathrm{E}+0.5$ \\
\hline${ }^{90} Y$ & $2.221 E+05$ & $1.111 E+05$ \\
\hline${ }^{106} \mathrm{Ru}$ & $9.312 \mathrm{E}+01$ & $4.656 \mathrm{E}+01$ \\
\hline${ }^{106} \mathrm{Rh}$ & $9.312 E+01$ & 4.656 E+01 \\
\hline${ }^{125} \mathrm{Sb}$ & $5.819 E+02$ & $2.909 E+02$ \\
\hline${ }^{125 \mathrm{~m}_{\mathrm{Te}}}$ & $1.420 \mathrm{E}+02$ & $0.710 E+02$ \\
\hline${ }^{134} \mathrm{Cs}$ & $2.195 E+02$ & $1.098 E+02$ \\
\hline${ }^{137} \mathrm{Cs}$ & $2.286 E+05$ & $1.143 E+0.5$ \\
\hline${ }^{137 m_{\mathrm{Ba}}}$ & $2.163 E+05$ & $1.082 \mathrm{E}+05$ \\
\hline${ }^{144} \mathrm{Ce}$ & $2.383 E+02$ & $1.192 \mathrm{E}+02$ \\
\hline${ }^{144} \mathrm{Pr}$ & $2.383 E+02$ & $1.192 \mathrm{E}+02$ \\
\hline${ }^{147} \mathrm{Pm}$ & $4.195 E+04$ & $2.098 E+04$ \\
\hline${ }^{151} \mathrm{Sm}$ & $6.285 E+03$ & $3.143 E+03$ \\
\hline${ }^{154} \mathrm{Eu}$ & $1.847 \mathrm{E}+02$ & $0.924 E+02$ \\
\hline${ }^{155} \mathrm{Eu}$ & $9.962 E+02$ & $4.981 E+02$ \\
\hline \multicolumn{3}{|l|}{ Transuranics } \\
\hline${ }^{237} \mathrm{~Np}$ & $9.919 \mathrm{E}-01$ & $4.960 \mathrm{E}-01$ \\
\hline${ }^{238} \mathrm{Pu}$ & $9.773 E+03$ & $4.886 \mathrm{E}+03$ \\
\hline${ }^{239} \mathrm{Pu}$ & $8.524 E+00$ & $4.262 E+00$ \\
\hline${ }^{240} \mathrm{Pu}$ & $8.023 \mathrm{E}+00$ & $4.011 \mathrm{E}+00$ \\
\hline${ }^{241} \mathrm{Pu}$ & $2.724 E+03$ & $1.362 E+03$ \\
\hline${ }^{241} \mathrm{Am}$ & $6.094 E+01$ & $3.047 \mathrm{E}+01$ \\
\hline${ }^{242 \mathrm{~m}} \mathrm{Am}$ & 5.109 E-01 & 2.555 E-01 \\
\hline${ }^{242} \mathrm{Am}$ & $5.083 \mathrm{E}-01$ & $2.542 \mathrm{E}-01$ \\
\hline${ }^{243} \mathrm{Am}$ & $3.282 \mathrm{E}+00$ & $1.641 \mathrm{E}+00$ \\
\hline${ }^{242} \mathrm{Cm}$ & $4.213 \mathrm{E}-01$ & 2.107 E-01 \\
\hline${ }^{243} \mathrm{Cm}$ & 6.929 E-01 & 3.465 E-01 \\
\hline${ }^{244} \mathrm{Cm}$ & $3.779 E+02$ & $1.890 \mathrm{E}+02$ \\
\hline
\end{tabular}

a. Only radionuclides that are used to detine the waste class and those in significant quantities are listed here for comparison purposes. For complete ORIGEN-Code listing, see DOE/RW-0184-R1.8 
The radionuclide inventories calculated using the reactor parameters, neutron cross-section parameters, and early version of the ORIGEN code should be viewed as suspect because of accuracy of data and assumptions used. ${ }^{d}$ Therefore, the data should only be used for planning purposes unless otherwise shown to be more recent and accurate.

d. Personal communication, A. G. Croff, Oak Ridge National Laboratory, July 1992. 


\section{REGULATORY REQUIREMENTS}

\subsection{Air Quality}

A number of different regulatory rules/standards are applicable to graphite waste management activities. The Clean Air Act (CAA) is the pre-eminent regulatory statute for any process or activity that will generate air emissions. The CAA requires the Environmental Protection Agency (EPA) to establish regulatory standards for all toxic or hazardous air pollutants under the National Emission Standards for Hazardous Air Pollutants (NESHAPs). ${ }^{18}$ Within NESHAPs, limits have been set for radioactive emissions from the DOE, Nuclear Regulatory Commission (NRC), and other Federal facilities. Additionally, the NRC has promulgated standards for radioactive emissions from the commercial nuclear industry. ${ }^{19}$ The EPA standards are given as an exposure limit in millirem (mrem) per year to onsite and offsite personnel and members of the genoral public, respectively. The NRC standards are given as activity per volume $(\mathrm{Ci} / \mathrm{mL})$ of a specific radionuclide at the site boundary. The EPA standards are stated in 40 CFR Part 61, and the NRC standards are detailed in 10 CFR Part 20 Appendix B. DOE has adopted the EPA's exposure based emission limits in DOE Order $5400.5^{20}$

As indicated, Rover and FSV graphite fuels contain radionuclides that are regulated relative to their emissions from a treatment, storage, or disposal facility. The radionuclides of most concern and abundance in the FSV fuel after a 10-year decay time are listed in Table 6. The NRC concentration limits are scheduled to be amended in February 1993 with the listed changes in emission standards stated in Appendix B to $\$ \$ 20.1001-20.2401$. Table 2, of the 10 CFR 20 standards. A commercial incineration processing option would be controlled by these regulations.

\subsection{Radiation Safety}

The applicable radiation safety regulations are the NRC's Radiation Protection Standards in 10 CFR Part 20, EPA's NESHAPS standards in 40 CFR Part 61, and radiation protection standards in DOE Order 5400.5.

Emission standards and radiation protection standards are typically in dose exposure units of mrem per year based on critical population groups or individual effective dose equivalents.

\subsection{Resource Conservation and Recovery Act Applicability}

There has been some concern and periodic discussion over the last 5 years concerning the applicability of EPA's 40 CFR $261^{21}$ and 40 CFR $191^{22}$ regulations with respect to spent fuels. In order for a material to be classified as a hazardous waste regulated by the Resource Conservation and Recovery Act (RCRA) regulations, two criterion must be met: (1) the material must be identified as a solid waste and (2) the material must exhibit hazardous characteristics or contain listed hazardous constituents. $^{21}$

The FSV fuel is not defined as a solid waste because source, special nuclear, and by-product materials are excluded from the solid waste definition under $\$ 261.4(a)(4)$ of 40 CFR Part 261. Additionally, the FSV fuel does not exhibit any hazardous characteristics nor contain any listed 
hazardous constituents as identified in Subparts C and D of 40 CFR 261, respectively. Therefore, the FSV fuel is excluded from RCRA waste regulations.

From a disposal perspective, 40 CFR 191.12(b) ${ }^{20}$ defines waste "as any spent fuel or radioactive waste isolated in a disposal system." Thus the spent fuel, once placed in a disposal system (e.g., geologic repository), v:ould be considered a waste and will then be regulated by 40 CFR 191 regulations.

\subsection{National Environmental Policy Act Applicability}

The National Environmental Policy Act (NEPA) pertains to any Federal activity and, therefore, will be a regulatory ruirement that must be met. Currently, the NEPA requirements are being addressed for the FSV fuel through a transportation environmental assessment for transporting the FSV fuel from Colorado to the INEL and an Action Description Memorandum (ADM) for FSV fuel performance and waste disposal research and development (R\&D) activities. The ADM is the document used to make a determination on whether the action requires the levelopment of an environmental assessment or an environmental impact statement. New NEPA documentation would need to be developed if the Rover facility was to be restarted.

\subsection{Low-Level Waste Regulations}

The NRC "Licensing Requirements for Land Disposal of Radioactive Waste," 10 CFR 61, ${ }^{23}$ DOE Order 5820.2A "Management of Low-Level Radioactive Waste," and EPA proposed "Environmental Radiation Protection Standards for Low-Level Radioactive Waste Disposal"25 regulate the disposal of low-level radioactive (LLW) waste.

The NRC T.LW standards define the classification of the waste and dictate the acceptable waste disposal methods for the commercial nuclear industry. Waste classifications of $\mathrm{A}, \mathrm{B}$, and $\mathrm{C}$ are acceptable for near-surface disposal (i.e., shallow land burial) with certain engineered barriers criteria for containment that increases per class designation. The greater than Class-C (GTCC) waste classification, based on the radionuclide concentrations in $10 \mathrm{CFR} 61.55$, excludes the waste from being shallow-land buried (i.e., $<5 \mathrm{~m}$ depth).

Tables 7 and 8 give the concentration limits for long- and short-lived radionuclides, respectively. ${ }^{23}$ The classification of a waste containing both long- and short-lived radionuclides, as is the case for FSV fuel, is determined as follows:

1. If the concentration of a nuclide listed in Table 7 does not exceed 0.1 times the Table 7 value, the class is determined by the concentration of nuclides listed in Table 8.

2. If the concentration of a nuclide listed in Table 7 exceeds 0.1 times the value in Table 7 but does not exceed the value in Table 7 , the waste is Class $\mathrm{C}$, provided the concentration of nuclides listed in Table 8 does not exceed the value in column 3 of Table 8.

The proposed DOE 5820.2A criteria follows in general principle those established in 10 CFR 61 . Waste classifications are identilied with respective standards for disposal. In the specific case of 
Table 7. Concentrations for long-lived radionuclides.

\begin{tabular}{lc}
\hline \multicolumn{1}{c}{ Radionuclide } & $\begin{array}{c}\text { Concentration limits } \\
\left(\mathrm{Ci} / \mathrm{m}^{3}\right)\end{array}$ \\
\hline${ }^{14} \mathrm{C}$ & 8 \\
${ }^{14} \mathrm{C}$ in activated metal & 80 \\
${ }^{59} \mathrm{Ni}$ in activated metal & 220 \\
${ }^{94} \mathrm{Nb}$ in activated metal & 0.2 \\
${ }^{99} \mathrm{Tc}$ & 3 \\
${ }^{129} \mathrm{I}$ & 0.08 \\
${ }^{\mathrm{Alpha}}$ & $100 .^{\mathrm{a}}$ \\
${ }_{\text {half-life greater than } 5 \text { years }}$ & \\
${ }^{241} \mathrm{Pu}$ & $3,5000^{\mathrm{a}}$ \\
${ }^{242} \mathrm{Cm}$ & $20,0000^{\mathrm{a}}$ \\
\end{tabular}

a. Units are in nanocuries per gram.

Table 8. Concentrations for short-lived radionuclides.

\begin{tabular}{|c|c|c|c|}
\hline \multirow[b]{2}{*}{ Radionuclide } & \multicolumn{3}{|c|}{ Concentration limits $\left(\mathrm{Ci} / \mathrm{m}^{3}\right)$} \\
\hline & Class $\mathrm{A}$ & Class B & Class $\mathrm{C}$ \\
\hline $\begin{array}{l}\text { Total of all nuclides with less than 5-year } \\
\text { half life }\end{array}$ & 700 & a & a \\
\hline${ }^{3} \mathrm{H}$ & 40 & a & a \\
\hline${ }^{60} \mathrm{Co}$ & 40 & a & a \\
\hline${ }^{63} \mathrm{Ni}$ & 3.5 & 70 & 700 \\
\hline${ }^{63} \mathrm{Ni}$ in activated metal & 35 & 700 & 7000 \\
\hline${ }^{90} \mathrm{Sr}$ & 0.04 & 150 & 7000 \\
\hline${ }^{137} \mathrm{Cs}$ & 1 & 44 & 4600 \\
\hline
\end{tabular}

a. There are no limits established for these radionuclides in Class B ur $\mathrm{C}$ wastes. Practical considerations such as the effects of external radiation and internal heat generation on transportation, handling, and disposal will limit the concentrations for these wastes. These wastes shail be Class B unless the concentrations of other nuclides in Table 8 determine the waste to be Class $C$ independent of these nuclides. 
GTCC, the current philosophy of DOE 5820.2A is to assess the disposal on a case-by-case basis for disposal requirements.

The establishment of the EPA's proposed LLW criteria is pending. The Office of Management and Budgets suspended review of 40 CFR 193, LLW criteria, until the EPA and NRC resolve their differences on establishment of safe and consistent standards. ${ }^{e}$

\subsection{Geologic Repository Waste Acceptance Regulations}

The geologic-repository disposal alternative is regulated by the EPA "Environmental Radiation Protection Standards for Management and Disposal of Spent Nuclear Fuel, High-Level and Transuranic Wastes" (40 CFR Part 191) ${ }^{22}$ and NRC "Disposal of High-Level Radioactive Waste in Geologic Repositories" (10 CFR 60). ${ }^{26}$ The EPA's limit (10 CFR 191.13) on radionuclide release from a repository to the accessible environment is given in terms of curies of specific radionuclides per 1,000 MTIHM over a period of 10,000 years after placement in the repository. The NRC's regulations [10 CIR 60.113 (a)(ii)(B)] limit the releases from the engineered barrier system to a fraction of $1 \times 10^{-5}$ per year of the radionuclide inventory that exists in the repository 1,000 years after closure. The impact of these repository requirements are discussed in Section 5.2, Whole Block Disposal.

e. Personal communication, J. Gruhlke, July 1992. 


\section{ALTERNATIVES IDENTIFICATION}

Extensive efforts to develop a reprocessing methodology for FSV's HTGR prism type fuel have been conducted. The General Atomic Company (GAC), developer of the HTGR prism fuel, ORNL, and WINCO researched and developed the crush-burn leach technology, which is the primary approach to graphite fuels reprocessing considered today. In most cases, the literature in the past was focused on a large scale processing for uranium recovery mode of analysis. Due to the new world political environment and the United States response to the changes that have occurred, reprocessing and recovery of fissile uranium from spent fuels is no longer a priority. Therefore, the process alternatives presented here focus on treatment and disposal of the spent fuel without dissolving and recovering the heavy metal. However, even from the waste management perspective, recovery of the uranium and storage in a stable suitable form may be an environmentally sound approach and may become an alternative if disposal criteria cannot be established or met.

\subsection{Modifications to Rover Technology}

As discussed in Section 2.1, the reuse of the existing Rover equipment is not a viable option. Thus, actual changes to the Rover equipment are not discussed here. However, the Rover technology (i.e., burn-leach) is a feasible approach to processing the FSV fuel and has been extensively evaluated. This section points out the process differences and modifications that would be required between Rover and FSV processing techniques. It should be noted that most of these changes have been researched in past HTGR cold pilot-scale processing projects.

\subsubsection{Physical}

The primary differences in FSV fuel compared to Rover fuel that must be addressed in a processing technology is the significantly larger size fuel elements and presence of the SiC-coated fuel kernels in the FSV fuel. Fluidized bed burning is most effective on feed material of a small particle size (e.g., 3/16 in. diameter). The small size of the feed material provides high surface area for increased combustion rates and allows for effective fluidization of the inert bed material and carbon material reducing the potential for stratification, plugging, or channeling within the burner. The small diameter (i.e., 3/4-in.) Rover fuel rods were successfully fed into the primary burner and allowed to disintegrate into smaller particles without the aid of an upfront size reduction step. The large size of the FSV fuel elements (i.e., $\sim 14$ in. across flats) cannot be physically fed into a fluidized bed burner system of any type. Crusning or shredding of the blocks into smaller particle sizes is necessary. Therefore, an additional size reduction step would have to be incorporated into the Rover process technology to allow processing of FSV fuel.

In addition to the physical size difference, the $\mathrm{SiC}$ coated fuel kernels must be processed in a different manner. The Rover-type fuel did not have the $\mathrm{SiC}$ coating and, therefore, was burned into an ash that could be elutriated (blown) out of the alumina fluidized bed. This type of operation will not be possible with the SiC fuel kernels in the FSV tuel. Two changes would have to be incorporated: (1) use of a bed of SiC fuel particles rather than the alumina bed material and (2) a batch type operation for the primary burning. This is not considered to be a design problem; the use of a $\mathrm{SiC}$ bed with batch operation to remove fuel kernels periodically has been tested on a pilotscale. $^{27-33}$ If complete recovery of the uranium/thorium was desired, a second crushing or breaking 
step and a fissile/fertile particle classification step would be necessary. The particle classification step is necessary to separate the uranium containing fissile particles trom the thorium rich fertile particles. To oxidize the uranium/thorium fuel and inner carbon layers of the FSV fuel in a secondary burning process, the $\mathrm{SiC}$ hull must be broken. The Rover process does not include either the particle classification step or the secondary crushing step.

\subsubsection{Chemical}

Since Rover fuel contained niobium carbide for nuclear-fuels protection in its coolant channels, $\mathrm{HF}$ in conjunction with $\mathrm{HNO}_{3}$ was necessary to dissolve the uranium-niobium compound. The FSV fuel does not contain niobium; therefore, dissolution of fuel can be performed using nitric acid alone. This does not pose a restriction on processing FSV fuel in a Rover-type system because the Rover process vessels are designed to handle both acids. It does, however, provide additional capabilities that are not necessary for FSV fuels.

\subsubsection{Offgas}

Comparison of fission product inventories presented in Tables 2 and 6 show that the FSV fuel is at least three orders of magnitude "hotter" than the Rover fuel with respect to high activity and long-lived radionuclides. This significant increase in fission product concentration will dictate that additional offgas pollution control equipment requirements must be evaluated. The volatile and semivolatile fission products that were of negligible concentration in the Rover offgas will be significantly higher in the FSV fuel processing offgas. Primary gaseous radioisotopes of concern are ${ }^{129} \mathrm{I},{ }^{85} \mathrm{Kr}, \mathrm{Xe},{ }^{106} \mathrm{Ru},{ }^{137} \mathrm{Cs}$, and ${ }^{14} \mathrm{C}$. The concentrations of these radionuclides in curies per unit volume will depend on the specific burning parameters (e.g., temperature, pressure, carbon loading, and excess air). Once these parameters are established, offgas concentrations at near-site boundary can be modelled to determine compliance with EPA, DOE, and NRC standards, 40 CFR 61, DOE Order 5400.5, and 10 CFR 20. If these standards are not met, the radioisotopes must be removed from the offgas.

Previous studies and operating systems have proven that pollution control technology and equipment are available to retain these gaseous radionuclides. ${ }^{34-38}$ Iodine is effectively removed using activated carbon adsorption or silver-zeolite ion exchange; ruthenium is removed using silica-gel beds; ${ }^{14} \mathrm{C}$ as ${ }^{14} \mathrm{CO}_{2}$ can be scrubbed out with calcium or barium hydroxide; cesium will condense upon cooling of the offgas stream and will be captured on HEPA tilters; and the ${ }^{85} \mathrm{Kr}$ and Xe can be cryogenically distilled from the offgas. Integration of these offgas pollution control units into a complete system poses the most significant $R \& D$ issue remaining to be addressed.

\subsection{Whole Block Disposal}

The whole block disposal concept is emplacement of the graphite fuel element block with fuel intact into an acceptable canister in a deep geologic repository such as Yucca Mountain.

A decision on direct disposal of graphite-based fuels versus reprocessing and conversion to a different waste form will need to take a number of key elements into account; one of them being 
repository waste acceptance criteria. Acceptance criteria have been proposed for reprocessed HLW forms, but criteria for spent fuel are not as explicit. Characterization of liquid water reactor (LWR) fuel is being performed in support of direct disposal, but no activities for defining the various performance characteristics of graphite fuels are being conducted. Lacking these criteria, one needs to look at the requirements of NRC 10 CFR 60 and EPA 40 CFR 191. Factors influencing the acceptability of this graphite-based fuel for repository disposal are the combustibility of the carbon, potential gas generation, organics, oxidation of the graphite with subsequent release of radionuclides (e.g., ${ }^{14} \mathrm{C}$ ), and thermal output.

One of the primary issues facing the Yucca Mountain repository is the very restrictive ${ }^{14} \mathrm{C}$ release limits set forth by the EPA and NRC. Several reports and studies have recently been performed addressing these restrictive limits. ${ }^{39-40}$ Without even considering graphite waste disposal, ${ }^{14} \mathrm{C}$ releases from the pressurized water reactor (PWR) and boiling water reactor (BWR) spent fuel assemblies pose a problem. Van Koynenberg ${ }^{40}$ calculated that breach of one LWR disposal container in 20,000 in a single year during the containment period, coupled with a $2 \%$ loss from the breached container, would exceed the DOE interpretation of "substantially complete containment." Additionally, the breach of one container in 2,000 in a single year during the controlled release period, coupled with a $2 \%$ loss from these containers, would violate the NRC 10 CFR 60 limit of one part in $10^{5}$ per year. The PWR and BWR fuel assemblies contain ${ }^{14} \mathrm{C}$ in median concentrations of $74 \mathrm{Ci} / \mathrm{GW}(\mathrm{e})$-year for BWRs and $59 \mathrm{Ci} / \mathrm{GW}(\mathrm{e})$-year for PWRs. This concentration compares to approximately $200 \mathrm{Ci} / \mathrm{GW}(\mathrm{e})$-year for HTGR spent fuel elements. ${ }^{15}$ Based on the significantly higher concentration of ${ }^{14} \mathrm{C}$ in the FSV fuel block versus the PWR and BWR fuel assemblies and the calculated release rates from Van Koynenberg ${ }^{40}$ stated above, it would not appear that packaged FSV fuel blocks would meet regulations either.

Limited oxidation and leachability tests have been conducted on FSV and Peach Bottom fuel element graphite ${ }^{40-43}$ that indicate the release of ${ }^{14} \mathrm{C}$ may in fact be lower from HTGR fuel than LWR fuel. Lotts ${ }^{44}$ used data from these experimental studies to evaluate the ${ }^{14} \mathrm{C}$ release from FSV fuel element graphite. Using an oxidation rate of $1.0 \mathrm{E}-17 \mathrm{~g} / \mathrm{cm}^{2}-\mathrm{sec}$ at $150^{\circ} \mathrm{C},{ }^{41}$ Lotts calculated the carbon loss per fuel element to be $1.6 \mathrm{E}-05 \mathrm{~g}$ /year. Using this oxidation rate and assuming a uniform distribution of ${ }^{14} \mathrm{C}$ in the graphite along with estimated heavy metal loadings and mass of carbon per fuel element, a release rate of $1.8 \mathrm{E}-06 \mathrm{Ci} /$ year is obtained. This is a fractional release of $1.8 \mathrm{E}-04$ of the EPA standard of $100 \mathrm{Ci}$ per 10,000 years for every $1,000 \mathrm{MTIHM}$ for ${ }^{14} \mathrm{C}$. In addition, Lotts determined that the NRC release of $10^{-5}$ fraction per year was met by the HTGR type fuel element.

Additionally, the combustibility limitation placed on the repository disposal scenario directly impacts the graphite waste form. Although difficult to technically show, the combustibility of bulk graphite is very low at low temperatures and low oxygen concentrations. The auto-ignition temperature of graphite is $725^{\circ} \mathrm{C}$ in air with slow reaction rates occurring at temperatures below $700^{\circ} \mathrm{C} .{ }^{45}$ Considering the temperatures generated by radiolytic decay in the Yucca Mountain repository are estimated to be $150^{\circ} \mathrm{C},{ }^{44}$ the waste canister specifications require a design life of 300 to 1,000 years, and the combination of high temperature and sufficient oxygen supply (although not statistically analyzed here) lead to the conclusion that the probability of ignition and sustained burning would be very low. However, the NRC regulatory criteria specifically states 
All combustible radioactive waste shall be reduced to a non-combustible form unless it can be demonstrated that fire involving the waste package containing combustibles will not compromise the integrity of other waste packages adversely affect any structures, systems, or components important to safety, or compromise the ability of the underground facility to contribute to waste isolation.

Under the right conditions, graphite combustion is a highly exothermic reaction that will quite easily breach metallic containers. The wording of the regulation assumes that conditions are such that a fire can exist, is sustainable, and does not allow for any probabilistic approach to qualify the thermal stability of graphite waste.

\subsection{Whole Block Crush-Burn Processing}

The whole-block crush-burn process concept is essentially the same as the Rover process technology with modifications described in Section 5.1; however, this alternative would be based on design and construction of a new processing system rather than modification of an old one. Considerable work has already heen performed by the GAC, ICPP, and ORNL to support this processing concept. ${ }^{31-38,46,47}$ Crushing the fuel element and feeding the crushed material into a fluidized bed burner has been considered to be the best method of head-end reprocessing of prismatic HTGR fuels. The fluidized bed burner provides high throughput rates that were envisioned to be necessary for large-scale reprocessing of future high volumes of HTGR fuels. The need for high throughput for the waste material in the United States will not be necessary until construction and operation of MHTGRs becomes a reality. Cold pilot-scale fluidized bed burner processes with headend crushing have been developed and operated by GAC and ICPP and are discussed here.

Engineering-scale development work was initiated by GAC with design and construction of a 8-in. internal diameter tluidized bed burner. A 16-in. primary burning system was also designed and operated in conjunction with the 8-in. system. These burner systems, as well as a 4-in. fluidized bed burner at ICPP, were operated on a cold-test basis in support of a planned large-scale demonstration facility. The process consists of crushing the large FSV graphite blocks to a maximum feed size of $3 / 16$ in. for effective fluidized bed operation. The GAC crushing operation consisted of a large uniframe triple stage jaw and roll-crusher unit. This unit, although effective in crushing the large FSV fuel elements, has limitations; highly mechanical equipment (i.e., a lot of moving parts) are difficult to operate and maintain in a remote operation application. Limited investigation into alternative crushing/sizing equipment more amenable to remote operation and maintenance has been pursued. ${ }^{\mathfrak{f}}$ Crushed material was pneumatically conveyed into the primary burner to oxidize the graphite. Graphite fines generated by the crushing and burning step, which were elutriated out of the primary burner, presented a high carbon secondary waste product (e.g., as much as $30 \%$ of graphite). Therefore, methods to recycle the fines to the primary burner for complete combustion were evaluated in both the GAC and ICPP development projects. The primary burner operated on a semicontinuous basis with fissile and fertile particles being withdrawn from the burner after recycling of the fines resulted in complete combustion of the graphite. Gas classification of the fertile and

f. Personal communication, W. B. Palmer, July 1992. 
fissile particles could then be accomplished before further processing. Breaking of the $\mathrm{SiC}$ hulls and exposing the inner layers of carbon and the $(\mathrm{U} / \mathrm{Th}) \mathrm{C}_{2}$ fuel was accomplished in a roll-crusher or jet grinder. Both methods of particle breakage have been evaluated at ICPP. ${ }^{48-49}$ Secondary burning of the fuel particles in another fluidized bed burner would then oxidize the remaining carbon and uranium and thorium carbides. The uranium-thorium rich ash is dissolved in a nitric acid solution and separated from the undissolved solids in a continuous solid-bowl centrifuge before the liquid-liquid extraction system.

From a waste management perspective, once the fissile and fertile fuel particles are separated from the graphite material, encapsulation of these coated particles in a glass matrix may provide a stable and acceptable waste form for repository disposal. This would be a point of departure from the current crush-burn-leach processing scenario described above.

An engineering-scale burner offgas (BOG) treatment system was also designed and operated by GAC to support testing of integrated offgas decontamination processes. ${ }^{34}$ The BOG treatment system employs components to remove ${ }^{3} \mathrm{H},{ }^{14} \mathrm{C},{ }^{85} \mathrm{Kr},{ }^{129} \mathrm{I}$, and ${ }^{220} \mathrm{Ru}$, as well as chemical forms of $\mathrm{CO}_{2}, \mathrm{CO}$, and $\mathrm{SO}_{2}$.

\subsection{Fuel-Rod Separation}

Fuel rod separation from the bulk graphite block making up the fuel element with disposal of the block as LLW would reduce the mass of spent fuel requiring HLW disposal by approximately $75 \%$. The subsequent disposal of the fuel rods by combustion of the graphite matrix and separation of the fuel kernels or direct disposal of the whole rod may be feasible. The potential advantage of this method of treatment is a 75\% reduction in the mass of graphite burned in the whole block crush burn option or directly disposed as in the whole block disposal option. The fuel rod matrix and PyC layers of the fuel kernels make up the other $25 \%$ of the carbon in a fuel element. In addition. separating the fuel rods from the graphite block before a burning process step would result in a significant reduction in the burner capacity required and in the volume of $\mathrm{CO}_{2}$ generated in the offgas. This reduced $\mathrm{CO}_{2}$ volume becomes significant if offgas scrubbing of ${ }^{14} \mathrm{C}$ and subsequent solidification as calcium-carbonate $\left(\mathrm{CaCO}_{3}\right)$ is necessary.

The reduction of the volume of waste requiring HLW or spent fuel disposal (i.e., deep geologic) is dependent on the fuel element block with fuel rods removed meeting LLW criteria. Therefore, the radionuclide concentration of the empty graphite block must be determined and compared with LLW criteria. Based on the ${ }^{14} \mathrm{~N}$ impurity level in the graphite of $26 \mathrm{ppm}$ and production of ${ }^{14} \mathrm{C}$ via the activation of ${ }^{13} \mathrm{C}$, an activity level of 0.16 curies per fuel element results. ${ }^{15}$ Considering the mass of carbon per fuel element with fuel rods removed is $0.0610 \mathrm{~m}^{3}$, the activity per volume is $2.6 \mathrm{Ci} / \mathrm{m}^{3}$, which compares to $3 \mathrm{Ci} / \mathrm{m}^{3}$ calculated by Lotts et al. ${ }^{44}$ This concentration of ${ }^{14} \mathrm{C}$ is within the $8 \mathrm{Ci} / \mathrm{m}^{3}$ for Class-C designation specified by $10 \mathrm{CFR}$ 61.55. Additionally, Lotts calculated the ${ }^{3} \mathrm{H}$ concentration to be $15 \mathrm{Ci} / \mathrm{m}^{3}$, which is well below the tritium limit for Class-A LLW of $40 \mathrm{Ci} / \mathrm{m}^{3}$. Thus, based on the radioactive activation products alone, the graphite block would pass as LLW. However, the actinides and fission products raise the classification of the empty fuel block to GTCC as discussed below. 
The release of the actinides and fission products that will contaminate the graphite block can occur in three ways: (1) fuel particle tailure as-manufactured, (2) fuel particle failure in-pile, and (3) fuel particle failure during processing. The as-manufactured fuel particle failure and in-pile fuel particle failure have been quantitatively estimated in a number of studies. The fuel particle failure during physical rod-removal is not known. However, data on fuel rod breakage during Post Irradiation Examination (PIE) of a FSV fuel element by $\mathrm{GAC}^{50}$ and particle failure during crushing of similar fuel rods determined by $O \mathrm{RNL}^{51}$ provide a basis to estimate the potential fuel particle breakage during processing. GAC reported that approximately $2 \%$ of the fuel rods that were removed from fuel element $1-0743$ were broken during push out, and $1 \%$ of the initial fuel rods were broken during assembly of the fuel element. Additionally, ORNL reported that there was a 5\% particle breakage associated with crushing and primary burning of TRISO-coated fissile particles in fuel rods from the fuel test element-four irradiated in the Peach Bottom Reactor.

Given the estimated rod and particle breakage and estimated fission product concentration in the fuel kernels calculated using the ORIGEN code, a release of radionuclides to the surrounding graphite block can be estimated. The calculations are included in Appendix B, which illustrates these estimated concentrations and the corresponding Class- $\mathrm{C}$ limits. The calculated concentrations are provided to show the potential magnitude of classifying the empty carbon block as LLW. Since the data were very limited, two calculations were performed. The first calculation was based on a conservative estimate of $100 \%$ fuel particle breakage per broken fuel rod, and the second calculation used a more realistic estimate of $5 \%$ particle breakage per broken fuel rod. In addition, a $50 \%$ reduction in ORIGEN code isotopic activity data was taken to account tor actual burnup being less than equilibrium burnup.

The fission products do not appear to impact the LLW classification of the graphite block even at $100 \%$ particle breakage. ${ }^{90} \mathrm{Sr},{ }^{137} \mathrm{Cs}$, and ${ }^{129} \mathrm{I}$ concentrations of 546,562 , and $3.1 \mathrm{E}-07 \mathrm{Ci} / \mathrm{m}^{3}$ are below the $7,000,4,600$, and $0.080 \mathrm{Ci} / \mathrm{m}^{3}$ Class-C limit. However, the potential release of the transuranic actinides clearly results in the classification of the graphite block as GTCC waste. The concentration of ${ }^{238} \mathrm{Pu}$ quickly escalates the waste into a GTCC status with ${ }^{241} \mathrm{Am}$ and ${ }^{244} \mathrm{Cm}$ also having significant impact. However, as mentioned in Section 3.3, using linear interpolation to estimate the transuranic nuclide content in fuel elements with less than $100,000 \mathrm{MWd} / \mathrm{MTIHM}$ will give conservative (i.e., too high) values. Additionally, the partitioning of the radionuclides once the fuel kernel is broken is not known. It is assumed that some of the radionuclides would not be released and of those released, some would be entrained in any localized ventilation air and some would remain on the graphite surface. However, based on these simplified assumptions and calculations the actinide concentrations would need to be reduced by a minimum of two orders of magnitude, or some form of decontamination process would need to be employed for the graphite block to meet LLW criteria. Applying less conservative parameters (i.e., only 5\% of kernels in broken rods fail) would still not reduce the actinide concentrations below Class-C limits. Further evaluation of characterization data, fuel particle breakage, and improved rod-removal techniques should answer the LLW classification question. 


\subsubsection{Processing Options Flow Diagram}

A process tlow diagram with decision points is provided in Figure 8 depicting the above waste management options and how they interrelate. The same options are depicted and evaluated by Lotts et al. ${ }^{44}$ Three potential seenarios are identified on the processing options diagram. A simplified mass balance on carbon was generated to compare the relative quantity of LLW and HLW going to disposal for each scenario. The basis for the calculations is a stoichiometric eonversion of carbon to carbon dioxide or calcium carbonate only.

In scenario 1, if direct whole block disposal is acceptable, -227 metric tons $\left(197 \mathrm{~m}^{3}\right)$ of carbon with 354 curies of ${ }^{14} \mathrm{C}$ would go to a geologic repository as HLW.

Scenario 2 is based on mechanical rod separation from the block, disposal of the empty carbon block as a LLW, and processing of the luel rods by burning with subsequent oflyas decontamination of $\mathrm{CO}_{2}$. This scenario results in 190 metric tons of carbon as graphite and $3(1) 9$ metric tons of carbon as $\mathrm{CaCO}_{3}$, for a total of 499 metric tons $\left(320 \mathrm{~m}^{3}\right)$ of carbon going to LLW disposal. This does not include any volume increase for solidification of the $\mathrm{CaCO}_{3}$ in cement nor other waste packaging. The quantity of material going to HLW disposal (i.e., geological repository) will depend on if the fuel kernels are processed to recover the heavy metals, or if the fuel kernels are packaged for direct disposal.

Scenario 3 represents the processing of the whole block in a combustion system with capture of $\mathrm{CO}_{2}$ from the ofligas and fuel kernel disposition in one of the two ways mentioned in Scenario 2. This scenario results in 1892 metric tons of $\mathrm{CaCO}_{3}$ (excluding mass and volume increase for soliditication in cement). The same amount of material will go to HLW disposal as in Scenario 2; thus, Scenario 3 represents almost a four-fold increase in material going to LLW disposal. 


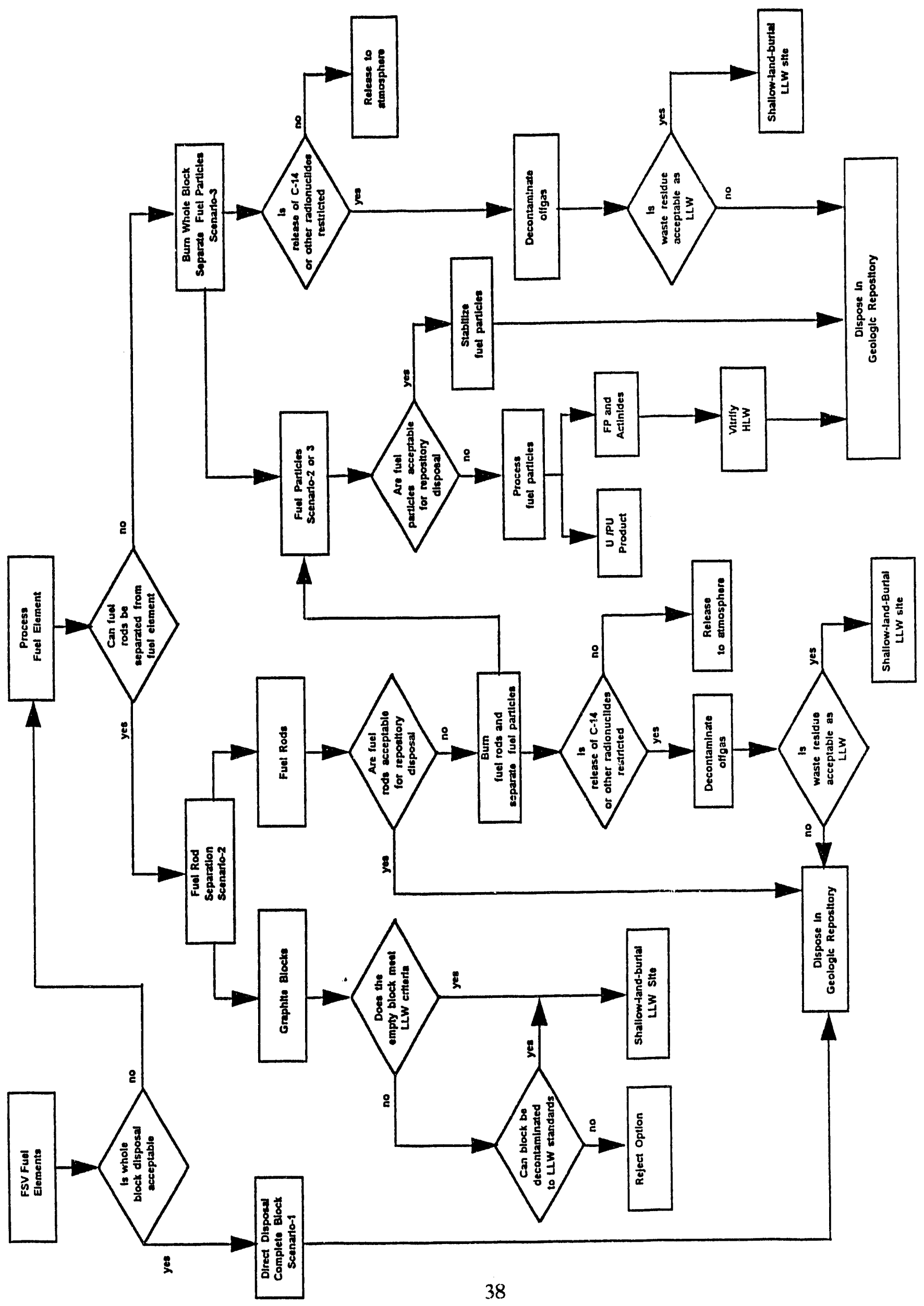

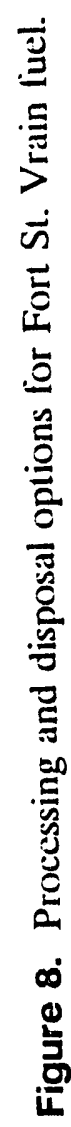




\section{CONCLUSIONS AND RECOMMENDATIONS}

\subsection{Conclusions}

Based on investigation of the available literature obtained and analysis pertormed within this report, a number of conclusions can be drawn.

First, the status of the existing Rover equipment and facility does not support reuse as is or with modifications for processing the FSV spent fuel material. The decontamination and decommissioning of the Rover equipment should proceed as currently envisioned with worker safety, material accountability, and environmental safety in mind.

Second, the experience and data available to support the burn-leach processing technology are extensive and well documented. The technology has been demonstrated on an operational basis with respect to the Rover process. Additionally, the technology has been demonstrated on a pilot-scale basis for the FSV fuel elements. Burner technology exists that will incinerate the graphite block and matrix material, and liquid-liquid extraction technology exists for recovery of the heavy metal values. The primary question to be resolved is whether there is a realistic option for disposal of the fuel particles that result from the head-end crushing and burning steps rather than processing to extract and recovering the heavy metals.

Third, further evaluation of the alternatives presented and discussed in key technical areas is required to come to the final conclusion on what is the best methodology and technology to treat and/or dispose of the FSV tuel. The following recommendations discuss the key areas where additional evaluation is deemed necessary to reach an optimal solution to this problem.

\subsection{Recommendations}

1. Determine through actual post irradiation study of the FSV fuel elements the concentration of radioactive contamination the graphite block material will absorb and retain after in-pile fuel particle failure and post irradiation mechanical fuel rod removal. This can be accomplished by analyzing the fuel element block residues from the GAC post irradiation examination of fuel element 1-0743 or implementing another PIE focusing on this specific parameter, as well as others. Additionally, radionuclide inventories determined through ORIGEN2 code may be improved upon since initial calculations.

2. Continue evaluating the geologic repository direct disposal option by analyzing the following:

a. The combustibility aspects of graphite fuels. Can a statistical and technical basis be made that will show the insignificant probability of waste combustibility and container destruction in the repository environment? 
b. What are the specific controls or waste package designs necessary to dispose of the complete fucl element as well as the separated fuel rods from a criticality, thermal output, waste package, and radionuclide containment perspective.

c. Current efforts to change the restrictive ${ }^{14} \mathrm{C}$ limits of release from a geologic repository for LWR fuels may support placement of graphite-based fuels in a repository environment. Comparison and analysis of the ${ }^{14} \mathrm{C}$ concentrations and estimated release rates of LWR versus graphite fuels need additional evaluation. Release of ${ }^{14} \mathrm{C}$ from shallow land burial of the graphite block as LLW should also be considered.

3. Continue evaluating the feasibility of block and rod separation to the extent that the characterization of the empty fuel element will be LLW. If the block can meet LLW classification consistently without secondary decontamination, then the engineering of a remote derodding facility should be pursued.

4. Examine the cost of crushing and burning the whole block for existing FSV and graphite fuels in storage without assuming future HTGR reprocessing. Determine if the crushing and burning process is a unit process that can be expanded easily if additional throughput capability is required in the future (e.g., 1-burner unit for FSV processing, 2-burners for future HTGR reactor fuels in 20 years)?

5. Perform a life-cycle cost-benefits analysis to economically evaluate alternative.

6. Establish a single team of experts in the HTGR/FSV fuel fabrication and processing arena to address each issue associated with each option and determine the best alternative to pursue and ultimately implement. This team of experts must be a small highly interactive working group with common goals. 


\section{REFERENCES}

1. Westinghouse Idaho Nuclear Company, Rover Fuels Processing Facility Final Safety Analysis Report, WIN-107-5.5, October 1983.

2. L. M. Ferris and L. A. Kambach, Uranium Recovery From Kiwi Fuel Elements: Laboratory Development, Oak Ridge National Laboratory, ORNL-3196, December 1961.

3. L. M. Ferris et al., Uranium Recovery From Kiwi-B Fuel Elements: Laboratory Development Part II, Oak Ridge National Laboratory, ORNL-3283, December 1962.

4. L. M. Ferris and K. S. Warren, Aqueous Processes for Uranium Recovery From Rover Fuel Elements: Laboratoly Development Part III Summary of the Processes, Oak Ridge National Laboratory, ORNL-3459, December 1963.

5. L. M. Ferris and K. S. Warren, Combustion-Dissolution Experiments with Iradiated Rover (KiwiB4A) Fuel, Oak Ridge National Laboratory, ORNL-TM-696, October 1963.

6. L. M. Ferris, A Burn-Leach Process for Recovery of Uranium From Rover Fuel: Terminal Report of Laboratory Development, Oak Ridge National Laboratory ORNL-3763, March 1965.

7. C. H. Fuller, Fort Saint Vrain Operational Experience, Public Service Company of Colorado.

8. U.S. Department of Energy, Office of Civilian Radioactive Waste Management Characteristics of Potential Repository Wastes, DOE/RW-0184-R1, Vol. 2, July 1992.

9. U.S. Department of Energy, "Nuclear Criticality Safety," DOE Order 5480.24, August 1992.

10. U.S. Department of Energy, "Safety of Nuclear Facilities," DOE Order 5480.5, September 1986.

11. U.S. Department of Energy Idaho Field Office, "Safety of Nuclear Facilities," DOE Order ID5480.5A, August 1990.

12. U.S. Department of Energy, "Nuclear Safety Analysis Reports," DOE Order 5480.23, April 1992.

13. American Nuclear Society, Nuclear Criticality Safety in Operations With Fissionable Materials Outside Reactors, ANSI/ANS-8.1, October 1983.

14. A. G. Croff, An Evaluation of Options Relative to the Fixation and Disposal of ${ }^{14} \mathrm{C}$-Contaminated $\mathrm{CO}_{2}$ as $\mathrm{CaCO}_{3}$, Oak Ridge National Laboratory, ORNL/TM-5171, April 1976.

15. W. Davis, Carbon-14 Production in Nuclear Reactors, Oak Ridge National Laboratory, ORNL/NUREG/TM-12, February 1977. 
16. National Council on Radiation Protection and Measurement, Carbon-14 in the Environment, NCRP Report No. 81, May 1985.

17. M. J. Bell, ORIGEN-The ORNL Isotope Generation and Depletion Code, Oak Ridge National Laboratory, ORNL-4628, May 1973.

18. Code of Federal Regulations, Title 40, Part 61, July 1990.

19. Code of Federal Regulations, Title 10, Part 20, January 1991.

20. U.S. Department of Energy, "Radiation Protection of the Public and Environment," DOE Order 5400.5, February 1990.

21. Code of Federal Regulations, Title 40, Part 261, July 1991.

22. Code of Federal Regulations, Title 40, Part 191, July 1991.

23. Code of Federal Regulations, Title 10, Part 61. January 1992.

24. U.S. Department of Energy, "Management of Low-Level Radioactive Waste," DOE Order 5820.2A, September 1988.

25. Federal Register 48, 39563, 1983.

26. Code of Federal Regulations, Title 10, Part 60, January 1992.

27. W. B. Palmer, Interim Results: Fines Recycle Testing Using the 4-Inch Diameter Primary Graphite Burner, Allied Chemical Corporation, ICP-1069, May 1975.

28. W. B. Palmer, Interim Experimental Results: Primary Graphite Burner Testing Without Fines Recycle, Allied Chemical Corporation, ICP-1068, June 1975.

29. G. W. Hogg et al., Interim Results: Development of A Head-End Process for Recovering Uranium and Thorium from Crushed Ft. St. Vrain Fuel, ICP-1074, October 1975.

30. N. D. Holder, Process Development Report: 0.40-m Circulating Bed Primary Burner System, GA Technologies, GA-A-17064, October 1983.

31. D. D. Jensen et al., Test Results From the GA Technologies Engineering-Scale Off-Gas Treatment System, GA Technologies, GA-A-17634, June 1984.

32. D. T. Young, Fluidized Combustion of Beds of Large, Dense Particles in Reprocessing HTGR Fuels, General Atomic Company, GA-A-14327, March 1977. 
33. R. T. Stula, et al., Interim Development Report for Primary Burning, General Atomics Company, GA-A13546, January 1976.

34 O. O. Yarbro et al., Effluent Control in Fuel Reprocessing Plants, Oak Ridge National Laboratory, ORNL-TM-3899, March 1974.

35 J. W. Snider and D. C. Watkins, An Evaluation of HTGR Primary Burning, Oak Ridge National Laboratory, ORNL-TM-4520, November 1974.

36. J. R. Flanary et al., Hot-Cell Evaluation of the Grind-Leach Process. 1. Irradiated HTGR Candidate Fuels: Pyrocarbon-Coated $(T H, U) C_{2}$ Particles Dispersed in Graphite, Oak Ridge National Laboratory, ORNL-4117, August 1967.

37. R. S. Lowrie, et al., "Determination of the Radioactive Nuclides Present in the Off-Gas Streams Generated by the Head-End Steps In Reprocessing HTGR Type Fuels," 12th AEC Air Cleaning Conference, Conf.-720823, Vol. 2, August 1972.

38. D. D. Jensen, et al., "'est Results from the GA Technologies Engineering-Scale Off-Gas Treatment System, General Atomic Company, GA-A17643, June 1984.

39. Science Application International Corporation, U-SUN Park, Regulatory Overview and Recommindations on a Repository's Release of Carbon-14, January 1992.

40. R. A. Van Konynenburg, "Gaseous Release of Carbon-14: Why the High-Level Waste Regulations Should be Changed," Lawrence Livermore National Laboratory, 2nd International High-Level /Radioactive Waste Management Conference, Vol. 1, April 18-May 3, 1991.

41. E. L. Fuller et al., Corrosion of Nuclear Grade Graphite: Air Oxidation of H-451, Oak Ridge National Laboratory, ORNL/GCR91/xxx (Draft).

42. E. A. Gulbransen and K. F. Andrew, "Reactions of Artificial Graphite," Industrial and Engineering Chemistry, 44 (No. 5) 1034-38, 1952.

43. G. Blyholder and H. Eyring, "Kinetics of Graphite Oxidation," Journal of Physical Chemistry, 61, 682-88, 1957.

44. A. L. Lotts et al., Options for Treating High-Temperature Gas-Cooled Reactor Fuel for Repository Disposal, Oak Ridge National Laboratory, ORNL/TM-12027, February 1992.

45. P. A. Haas, HTGR Fuel Reprocessing: A Whole-Block Burner with Recycle of Cooled Gas for Temperature control, Oak Ridge National Laboratory, ORNL-TM-4519, August 1974.

46. C. L. Fitzgerald, Head-End Reprocessing Studies with Irradiated HTGR-Type Fuels: III. Studies with RTE-7: Triso $U C_{2}$-Triso $T h C_{2}$, Oak Ridge National Laboratory, ORNL-5090, November 1975. 
47. R. W. Glass et al., HTGR Head-End Processing: A Preliminary Evaluation of Processes for Decontaminating Burner Off-Gas, Oak Ridge National Laboratory, ORNL-TM-3527, July 1972.

48. W. B. Palmer, Breaking Silicon Carbide Coated Unirradiated Ft. St. Vrain Fuel Particles by Jet Grinding, Allied Chemical Corporation, ICP-1043, April 1974.

49. W. B. Palmer, Experimental Testing of the Double-Roll Cnisher for Breaking Silicon Carbide Coatings on Unirradiated Ft. St. Vrain Fuel Particles, Allied Chemical Corporation, ICP-1070, April 1975.

50. J. J. Saurwein et al., Postirradiation Examination and Evaluation of Fort St. Vrain Fuel Element 1-0743, General Atomic Company, GA-A16258, May 1981.

51. C. L. Fitzgerald and V. C. Vaaughen, "Head-End Reprocessing Studies with Irradiated High Temperature Gas-Cooled Reactor (HTGR) Fuels," Oak Ridge National Laboratory Conference 800943-11, September 29-October 2, 1980. 
Appendix A

Processing Literature

A-1 
A-2 


\section{Appendix A}

\section{HTGR FUEL PROCESSING LITERATURE SEARCH SUMMARY ${ }^{\mathrm{a}}$}

\begin{tabular}{|c|c|c|c|c|}
\hline TOPIC & NUMBER $^{6}$ & DATE & LOCATION $^{c}$ & TITLE \\
\hline 1.00 & GA-A-13178 & 74.08 & $\bar{w}$ & CFR.33, JUNE-AUG. 1974 \\
\hline 1.00 & GA-A-13255 & 74.11 & $\bar{w}$ & CFR.32, SEPT.-NOV. 1974 \\
\hline 1.00 & GA-A-13366 & 75.02 & $\bar{w}$ & CFR.31, DEC. 1974-FEB. 1975 \\
\hline 1.00 & GA-A-13510 & 75.05 & W & CFR.30, MARCH-MAY 1975 \\
\hline 1.00 & GA-A-13593 & 75.08 & $\overline{\mathrm{w}}$ & CFR.29, JUNE-AUG. 1975 \\
\hline 1.00 & GA-A-13746 & 75.11 & $\bar{W}$ & CFR.28, SEPT.-NOV. 1975 \\
\hline 1.00 & GA-A-13833 & 76.02 & $\bar{w}$ & CFR.27, DEC. 1975-FEB. 1976 \\
\hline 1.00 & GA-A-13949 & 76.05 & $\bar{W}$ & CRF.26, MARCH-MAY 1976 \\
\hline 1.00 & $G A \cdot A-14085$ & 76.08 & $\bar{W}$ & CFR.25, JUNE-AUG. 1976 \\
\hline 1.00 & GA-A-14104 & 76.10 & $S$ & ANALYTICAL CHEMICAL DEPARTMENT ANNUAL REPORT \\
\hline 1.00 & GA-A-14214 & 76.11 & W & CFR.24, SEPT.-NOV, 1976 \\
\hline 1.00 & GA-A-14304 & 77.02 & W & CFR.23, DEC.-FEB. 1977 \\
\hline 1.00 & GA-A-14441 & 77.05 & W & CFR.22, MARCH-MAY, 1977 \\
\hline 1.00 & GA-A-14583 & 77.09 & W & CFR.21, JUNE-AUG. 1977 \\
\hline 1.00 & GA-A-14738 & 77.12 & $\bar{W}$ & CFR.20, SEPT.-NOV. 1977 \\
\hline 1.00 & GA-A-14878 & 78.02 & W & CFR.19, DEC. 1977-FEB. 1978 \\
\hline 1.00 & GA-A-15011 & 78.05 & $\bar{W}$ & CFR.18, MARCH-MAY 1978 \\
\hline 1.00 & GA-A-15105 & 78.09 & W & CFR.17, JUNE-AUG. 1978 \\
\hline 1.00 & GA-A-15315 & 79.02 & $\bar{w}$ & CFR.14, SEPT. 1978-FEB. 1979 \\
\hline 1.00 & GA-A-15440 & 79.05 & $\bar{w}$ & CFR.13, MARCH-MAY 1979 \\
\hline 1.00 & GA-A-15568 & 79.09 & W & CFR.12, AUG. 1979 \\
\hline 1.00 & ORNL-2392 & 57.05 & w & CHEM. TECH. DIV. ANN. REPORT/ENDING 8/31/57 \\
\hline 1.00 & ORNL-2576 & 58.05 & $\mathrm{~A}$ & CHEM. TECH. DIV. ANN. REPORT/ENDING 8/31/58 \\
\hline 1.00 & ORNL-2788 & 59.05 & $\bar{w}$ & CHEM. TECH. DIV. ANN. REPORT/ENDING 8/31/59 \\
\hline 1.00 & ORNL-2993 & 60.05 & $\bar{W}$ & CHEM. TECH. DIV. ANN. REPORT/ENDING $5 / 31 / 60$ \\
\hline 1.00 & ORNL-3153 & 61.05 & $\overline{\mathrm{A}}$ & CHEM. TECH. DIV. ANN. REPORT/ENDING 5/31/61 \\
\hline 1.00 & ORNL-3314 & 62.05 & $\bar{w}$ & CHEM. TECH. DIV. ANN. REPORT/ENDING 5/31/62 \\
\hline 1.00 & ORNL-3445 & 63.03 & $\bar{w}$ & GCR-PROG. REPORT EDNING MARCH 31, 1963 \\
\hline 1.00 & ORNL-3452 & 63.05 & $\bar{W}$ & CHEM. TECH. DIV. ANN. REPORT/ENDING 5/31/63 \\
\hline 1.00 & ORNL-3627 & 64.05 & w & CHEM. TECH. DIV. ANN. REPORT/ENDING 5/31/64 \\
\hline 1.00 & ORNL-3830 & 65.05 & $\bar{W}$ & CHEM. TECH. DIV. ANN. REPORT/ENDING 5/31/65 \\
\hline 1.00 & ORNL-3945 & 66.05 & W & CHEM. TECH. DIV. ANN. REPORT/ENDING 5/31/66 \\
\hline 1.00 & ORNL-4145 & 66.05 & W & CHEM. TECH. DIV. ANN. REPORT/ENDING 5/31/67 \\
\hline 1.00 & ORNL-4272 & 68.09 & $\bar{w}$ & CHEM. TECH. DIV. ANN. REPORT/ENDING S/31/68 \\
\hline 1.00 & ORNL-5266 & 76.09 & $\bar{W}$ & THORIUM UTIL. PROGRAM PROG. REP. 7/1/75 TO 9/30/76 \\
\hline 1.00 & ORNL-5423 & 78.09 & W/S & HTGR FUEL RECYCLE DEV. APR/ENDING 9/30/77 \\
\hline 1.00 & ORNL-5423 & 77.09 & W & HTGR FUEL RECYCLE DEV. APR/ENDING 9/30/77 \\
\hline 1.00 & ORNL-TM-2792 & 70.01 & W & TH-FUEL CYCLE DEV. PROG. REP. NO.5. DEC. 1969 \\
\hline
\end{tabular}




\begin{tabular}{|c|c|c|c|c|}
\hline TOPIC & NUMBER $^{b}$ & DATE & LOCATION $^{C}$ & TITLE \\
\hline 1.00 & ORNL-TM-6719 & 78.12 & $\mathrm{~W}$ & CFRP, OCT. 1-DEC. 31,1978 \\
\hline 1.00 & ORNL-TM-6836 & 79.03 & W & CFRP, JAN. 1-MAR. 31, 1979 \\
\hline 1.00 & ORNL-TM-7192 & 79.12 & W & CFR.11, OCT. 1-DEC. 31. 1979 \\
\hline 1.00 & ORNL-TM-7430 & 80.06 & $w$ & CFR.10, APRIL 1-JUNE 30, 1980 \\
\hline 1.00 & ORNL-TM-7557 & 80.09 & W & CFR.9, JULY 1-DEPT. 30, 1980 \\
\hline 1.00 & ORNL-TM-7657 & 80.12 & $W$ & CFR.8, OCT. 1-DEC. 31,1980 \\
\hline 1.00 & ORNL-TM-7773 & 81.03 & W & CFR.7, JAN. 1-MARCH 31, 1981 \\
\hline 1.00 & ORNL-TM-7914 & 81.06 & W & CFR.6, APRIL 1-JUNE 30, 1981 \\
\hline 1.00 & ONRL-TM-8030 & 81.09 & $\mathrm{~A}$ & CFR.5, JULY-SEPT. 31,1981 \\
\hline 1.00 & ORNL-TM-8199 & 81.12 & W & CFR.4, OCT. 1-DEC. 31,1981 \\
\hline 1.00 & ORNL-TM-8435 & 82.06 & W & CFR.3, APRIL-JUNE 30,1982 \\
\hline 1.00 & ORNL-TM-8537 & 82.09 & W & CFR.2, JULY 1-SEPT. 30, 1982 \\
\hline 1.00 & ORNL-TM-8613 & 82.12 & $\mathrm{~W} / \mathrm{S}$ & CFR.1, OCT. 1-DEC. 31, 1982 \\
\hline 2.00 & ORNL-4327 & 68.12 & w & MECHANICAL PROPERTIES OF ARTIFICIAL GRAPHITES \\
\hline 2.00 & ONRL-TM-2715 & 69.11 & W & ROLE OF C IN RXNS IN U-C-O-N SYSTEM \\
\hline 2.00 & ORNL-TM-2727 & 69.12 & $\mathbf{W}$ & MECHANICAL BEHAVIOR OF ARTIFICIAL GRAPHITES \\
\hline 3.00 & CONF-800943-11 & 80.01 & $\mathrm{~S}$ & $\begin{array}{l}\text { HEAD-END REPROCESSING STUDIES WITH IRRADIATED HTGR } \\
\text { FUELS }\end{array}$ \\
\hline 3.00 & GA-A-13279 & 75.02 & $S$ & REPROCESSING DEVELOPMENT FOR HTGR FUELS \\
\hline 3.00 & GA-A-13808 & 76.04 & $\mathrm{~S}$ & FLOWSHEET DEVELOPMENT FOR HTGR FUEL REPROCESSING \\
\hline 3.00 & GA-A-13860 & 76.05 & $\mathrm{~S}$ & HTGR SPENT REFLECTOR BLOCK DISPOSAL OF GRAPHITE WASTE \\
\hline 3.00 & DP-461 & 67.02 & W & HEADEND/U AND TH-CARBIDE GRAPHITE FUEL \\
\hline 3.00 & GA-A-14320 & 77.08 & $w$ & REPRO.YIELDS/MATER.THROUGHPUT-HTGR DEMO. FAC. \\
\hline 3.00 & GA-A-1462 & 77.12 & $\bar{W}$ & GARPP: DESCRIP. \& RESULTS/INITIAL TESTING \\
\hline 3.00 & $G A-A-15081$ & 78.09 & W & GA-HTGR FRPP:RESULTS/INITIAL SEQUENTIAL EQUIP. OP. \\
\hline 3.00 & GA-A-15145 & 78.10 & W & REPRO. FLOWSHEET/MATERIAL BALANCE/MEU SPENT FUEL \\
\hline 3.00 & GA-A-15343 & 79.05 & $\mathrm{~W}$ & HTGR FRPP:RESULTS/SEQUENTIAL EQUIP. OPERATION \\
\hline 3.00 & GA-A-15487 & 79.08 & $\mathrm{~W}$ & THERMAL ASPECTS/DESIGN OF HTGR FUEL REPRO. PLANT \\
\hline 3.00 & GA-A-16111 & 80.11 & $\mathrm{~W} / \mathrm{S}$ & PROCESS/FRG MIXED OXIDE FE/GA UNDER US/FRG COOP. \\
\hline 3.00 & GA-A-16405 & 81.07 & W & SPENT GRAPHITE FUEL ELEMENT PROCESSING \\
\hline 3.00 & GA-A-16567 & 81.00 & $\mathrm{~W}$ & PROCESSING OF FRG HTGR FUEL ELEMENTS \\
\hline 3.00 & GA-A-17601 & 84.12 & $\mathrm{~W}$ & HTGR SPENT FUEL TREATMENT DEVEL. PROGRAM \\
\hline 3.00 & GA-A-17625 & 84.08 & W/S & ADVANCES/HTGR SPENT FUEL TREATMENT TECHNOLOGY \\
\hline 3.00 & GEHTR-139 & 74.08 & $\mathrm{~W}$ & TRTIUM IN REPROCESSING PLANTS \\
\hline 3.00 & GEHTR-140 & 74.08 & W & REPRO./TH-BEARING NUCLEAR FUELS ANNUAL REPORT \\
\hline 3.00 & GEHTR-182 & na & $\mathrm{W}$ & VENUS COLD PROTO. INSTALL./HEAD-END/REPRO/HTR FE \\
\hline 3.00 & GEHTR-183 & na & $\mathrm{w}$ & REPRO. OF TH-CONTAINING NUCLEAR FUELS \\
\hline 3.00 & ICP-1074 & 75.10 & $\mathrm{~W} / \mathrm{S}$ & $\begin{array}{l}\text { INTERIM RES/DEVEL./HEADEND/RECOVER. U AND TH/CRUSHED } \\
\text { FSVR }\end{array}$ \\
\hline 3.00 & JUEL-SPEZ-130 & 81.10 & $\mathrm{~W}$ & CHEM/PROC. TECH. FOR HEADEND REPRO./HTR FUEL ELE. \\
\hline 3.00 & JUEL-SPEZ-239 & 84.01 & $\mathrm{~W}$ & REPRO. IN THORIUM FUEL CYCLE-A PROBLEM LIST \\
\hline 3.00 & JUL-CONF-30 & 79.02 & A & TROPICAL SEM./REPRO./DISPOSAL IN TH. FUEL CYCLE \\
\hline 3.00 & $\begin{array}{l}\text { KERNTECHNIK } \\
\text { V.8 }\end{array}$ & 66.00 & $\bar{W}$ & REPROCESSING OF CARBIDE FUEL PARTICLES \\
\hline 3.00 & ORNL-2761 & 60.04 & $\bar{A}$ & GRIND-LEACH/U AND TH RECOVERY FROM GRAPHITE \\
\hline 3.00 & ORNL-3186 & 61.10 & A & GRIND-LEACH/U AND TH RECOVERY/PART II \\
\hline
\end{tabular}




\begin{tabular}{|c|c|c|c|c|}
\hline TOPIC & NUMBER $^{b}$ & DATE & LOCATION $^{\mathrm{C}}$ & TITLE \\
\hline 3.00 & ORNL.5090 & 75.11 & W/S & HEADEND REPRO STUDIES/III/RTE-7:TRISO UC2, TRISO THC2 \\
\hline 3.00 & Cont. $.800943-11$ & 80.11 & $\mathbf{S}$ & HEADEND REPRO. STUDIES W/IRRADIATED HTGR-TYPE FUELS \\
\hline 3.00 & ORNL-TM-1139 & 65.05 & $\bar{w}$ & $\begin{array}{l}\text { REPRO. METHODS/COSTS/SELECTED TH-BEARING REACTOR FUEL } \\
\text { TYPES }\end{array}$ \\
\hline 3.00 & ORNL-TM-1411 & 66.02 & $\bar{w}$ & $\begin{array}{l}\text { SURVEY/HEADEND PROC./RECOVERY U \& TH/GRAPHITE-BASE } \\
\text { FUELS }\end{array}$ \\
\hline 3.00 & ORNL-TM-2377 & 68.10 & $\bar{w}$ & ECON. \& TECHNOLOGY/HTGR FUEL RECYCLE \\
\hline 3.00 & ORNL-TM-2389 & 69.02 & $\bar{w}$ & $\begin{array}{l}\text { HEADEND STUDIES/SIC-COATED HTGR FUELS/UNIRR. DRAGON } \\
\text { COMPACT }\end{array}$ \\
\hline 3.00 & ORNL-TM-241 & 62.07 & $\bar{A}$ & SURVEY OF TH-FUEL PROCESS METHODS \\
\hline 4.00 & ORNL-2640 & na & $\mathbf{A}$ & \\
\hline 4.00 & ORNL-2761 & na & A & \\
\hline 4.00 & ORNL-4110 & 67.06 & $\mathrm{~W} / \mathrm{S}$ & $\begin{array}{l}\text { GRIND-LEACH/GRAPHITE-BASE FUELS/CONTAIN COATED } \\
\text { PARTICLES }\end{array}$ \\
\hline 4.00 & ORNL-4117 & 67.08 & W/S & HOT-CELL EVAL/GRIND-LEACH PROCESS-I. IRR. HTGR FUELS \\
\hline 4.00 & ORNL-4213 & 68.03 & $\bar{W}$ & HOT-CELL EVAL-GRIND-LEACH PROCESS/U/TH/SOL-GEL \\
\hline 4.00 & ORNL-TM-1412 & 66.02 & $\bar{w}$ & BALL-MILLING OF GRAPHITE BASE REACTOR FUEL \\
\hline 4.00 & ORNL-TM-1880 & 67.05 & $\bar{W}$ & HOT CELL EVAL/GRIND-LEACH/IRRADIATED PYROLYTIC/SOL-GEL \\
\hline 5.00 & JUL-1152 & 75.01 & $\mathbf{A}$ & COMPARISON OF SHAFT FURNACE AND FLUIDIZED BED \\
\hline 5.00 & ORNL-3763 & 65.03 & $\bar{w}$ & $\begin{array}{l}\text { BURN-LE.ACH PROCESS/REC. U/ROVER FUEL/CERMLAL REP. LAB } \\
\text { DEV. }\end{array}$ \\
\hline 5.00 & ORNL-4120 & 70.02 & $\bar{W}$ & $\begin{array}{l}\text { HOT-CELL EVAL/BURN-LEACH METHOD/REPRO. IRR. GRAPHITE } \\
\text { FUELS } \\
\end{array}$ \\
\hline 5.00 & ORNL-TM-1096 & 65.04 & $\bar{W}$ & $\begin{array}{l}\text { BURN-LEACH PRO./GRAPHITE FUELS W/C-COATED } \\
\text { CARBIDE/OXIDE PART. }\end{array}$ \\
\hline 5.00 & ORNL-TM-4520 & 74.01 & $\mathbf{S}$ & AN EVALUATION OF HTGR PRIMARY BURNING \\
\hline 5.00 & ORNL-TM-688 & 63.09 & W & $\begin{array}{l}\text { COMB/DISS. EXP/GRAPHITE-BASED FUEL/C-COATED TH-U } \\
\text { DICARBIDE }\end{array}$ \\
\hline 6.00 & KFA-ICT-IB-431/79 & 79.04 & A & GASSIFICATION AND MECHANICAL GRAPHITE SEPARATION \\
\hline 6.00 & KFA-ICT-IB-442/79 & 79.00 & $\mathrm{~A}$ & GRAPHITE RECOVERY FROM GASSIFICATION \\
\hline 6.00 & ORNL-TM-1430 & 66.03 & w & SUN. REP./RXN OF STEAM W/LARGE SPECIMENS/GRAPHITE/GCR \\
\hline 6.00 & ORNL-TM-2199 & 68.04 & W & $\begin{array}{l}\text { OXIDATION/PYRO-C-COATED FUEL PARTICLES/LOW CONC. H20 } \\
\text { VAPOR }\end{array}$ \\
\hline 6.00 & ORNL-TM-984 & 65.03 & $\bar{w}$ & RXN/STEAM W/LARGE SPECIMENS GRAPHTE FOR EXP. GCR \\
\hline 7.00 & GERHTR-141 & 74.10 & w & CHLORINEX \\
\hline 7.00 & ORNL-3434 & 63.10 & $\overline{\mathbf{w}}$ & RECOVERY/U FROM GRAPHITE FUELS/OXIDATION/FLUORINATION \\
\hline 7.00 & ORNL-3456 & 64.01 & $\bar{w}$ & OXIDATION/FLUORINATION MATHEMATICAL MODEL \\
\hline 7.00 & ORNL-3586 & 64.04 & $\bar{W}$ & $\begin{array}{l}\text { REMOVAL OF U \& TH FROM FUELED-GRAPHITE MAT. BY } \\
\text { CHLORINATION }\end{array}$ \\
\hline 7.00 & ORNL-3977 & 66.07 & $\bar{w}$ & OXIDATION/CHLORINATION UO2-PUO2 \\
\hline 7.00 & ORNL-TM-1340 & 65.10 & $\bar{W}$ & THERMO. CALCS./CHLORIDE VOLATILITY PRO. NUCLEAR FUELS \\
\hline 7.00 & ORNL-TM-1701 & 67.04 & $\bar{w}$ & $\begin{array}{l}\text { CONVERSION/U-CHLORIDES TO URANIA/GAS-PHASE RED. } \\
\text { HYDROLYSIS }\end{array}$ \\
\hline 7.00 & ORNL-TM-789 & 64.05 & $\bar{W}$ & CHLORINATING COMB. ASH/THC2/UC2/REC. U BY SOLV. EXT. \\
\hline 8.00 & $\begin{array}{l}\text { KERNTECHNIK } \\
\text { V.5 }\end{array}$ & na & $\bar{A}$ & na \\
\hline 8.00 & $\begin{array}{l}\text { KERNTECHNIK } \\
\text { V15 }\end{array}$ & na & $\bar{A}$ & na \\
\hline
\end{tabular}




\begin{tabular}{|c|c|c|c|c|}
\hline TOPIC & NUMBER & $\overline{\mathrm{DATE}}$ & LOCATIONC $^{\mathrm{C}}$ & TITLE \\
\hline 8.00 & CONF-860603-6 & 86.00 & $\bar{W}$ & POSTIRRADIATION EXAM. OF HTR FUEL (NABIELEK) \\
\hline 8.00 & ORNL-238 & 49.02 & $\mathrm{~A}$ & $\begin{array}{l}\text { RECOVERY OF U/GRAPHITE SHAPES/ECLECTRO. } \\
\text { DISINTEGRATION/HNO3 }\end{array}$ \\
\hline 8.00 & ORNL-TM-384 & 62.09 & A & U.TH RECOVERY/PYROLYTIC C.COATED PART./ELECTRO./HNO3 \\
\hline 8.00 & ORNL-TM-6426 & 78.12 & $\bar{W}$ & HTGR FUEL ROD DECONSOLIDATION \\
\hline 9.00 & LTC-2-88 & 88.06 & $\bar{S}$ & $\begin{array}{l}\text { RECOMMEND. FOR ROVER URANIUM RECOVERY AND SYSTEM } \\
\text { DISPOS. }\end{array}$ \\
\hline 9.00 & ORNL-2640 & na & A & TENTATIVE GRIND-LEACH PROCESS FOR ROVER FUELS \\
\hline 9.00 & ORNL-2640 & 59.01 & $\mathbf{W}$ & TENTATIVE GRIND-LEACH PROCESS FOR ROVER FUELS \\
\hline 9.00 & ORNL-2741 & na & $\bar{A}$ & ROVER FUEL REPROCESSING \\
\hline 9.00 & ORNL-3196 & 61.12 & $\mathbf{W} / \mathbf{S}$ & U RECOVERY FROM ROVER FUELS \\
\hline 9.00 & ORNL-3283 & 61.12 & W/S & U RECOVERY FROM ROVER FUELS \\
\hline 9.00 & ORNL. 3763 & 65.03 & $S$ & $\begin{array}{l}\text { A BURN-LEACH PRO. FOR REC. OF URAN. -ROVER FUEL: } \\
\text { TERM.LAB DEV }\end{array}$ \\
\hline 9.00 & ORNL-TM-170 & na & A & na \\
\hline 9.00 & ORNL-3376 & na & $\bar{W}$ & $\begin{array}{l}\text { LAB. DEV/CHLORIDE VOLATILITY/RECOVERY U/SPENT ROVER } \\
\text { FUEL/ASH }\end{array}$ \\
\hline 9.00 & ORNL.3376 & 63.06 & W/S & $\begin{array}{l}\text { LAB. DEV/CHLORIDE VOLATILITY/RECOVERY U/SPENT ROVER } \\
\text { FUEL/ASH }\end{array}$ \\
\hline 9.00 & ORNL-3435 & 63.06 & W/S & $\begin{array}{l}\text { LAB. DEV/RECOVER U/ROVER FUEL/COMBUST./LIQ. CHLOR. } \\
\text { HERACHLOR }\end{array}$ \\
\hline 9.00 & ORNL-TM-696 & 63.10 & W/S & COMB/DISS. EXP/IRRADIATED ROVER (KIWI-B4A) FUEL. \\
\hline 10.00 & $\begin{array}{l}\text { KERNTECHNIK } \\
\text { V.10 }\end{array}$ & 68.00 & WV & ACID/OXIDIZER/GRAPHITE DECONSOLIDATION \\
\hline 10.00 & NUREM-160 & 73.12 & A & ALTERNATIVE HEADEND PROCESSES/NOT BURNING \\
\hline 10.00 & ORNL-3219 & 62.02 & A & AQUEOUS PROCESSING OF THORIUM FUELS \\
\hline 10.00 & ORNL-3418 & 63.05 & A & AQUEOUS PROCESSING OF TH-FUELS/PART II \\
\hline 10.00 & ORNL-3459 & 63.12 & $\mathrm{~W} / \mathrm{S}$ & AQUEOUS PROC.U RECOVERY/ROVER FE/LAB. DEVEL. III \\
\hline 10.00 & ORNL-3660 & 64.09 & W & $\begin{array}{l}\text { HO'T-CELL STUDIES/AQUEOUS DISS. PROC./IRR. CARBIDE REAC. } \\
\text { FUELS }\end{array}$ \\
\hline 10.00 & ORNL-3719 & 64.12 & W & OFF-GASES/RXNS OF U-CARBIDES WITH HNO3 AT 90C \\
\hline 11.00 & ORNL-TM-800 & 64.04 & W/S & BIBLIO/ROVER FUEL PRO.MOLTEN SALT FLUORIDE VOLATILITY \\
\hline 11.00 & RWMADA & na & A & ${ }^{2}$ \\
\hline 12.00 & CNIC-I-002 & 87.09 & $\bar{A}$ & PROC. 6TH PACIFIC NUC. CONF/OUTLOOK OF NUC. TECH./1990'S \\
\hline 12.00 & DOE-HTGR-86-024 & 87.08 & $\bar{A}$ & PRELIM. SAFETY INFO. DOC. FOR STANDARD MHTGR (1987) \\
\hline 12.00 & DOE-HTGR-87.092 & 87.09 & A & CONCEPTUAL DESIGN SUM. REP.MMTGR PLANT \\
\hline 12.00 & GA-A-13174 & 74.11 & $\overline{\mathrm{S}}$ & CARBON-14 IN THE HTGR FUEL CYCLE \\
\hline 12.00 & GA-A-13708 & 75.11 & S & WASTE MGMT. IN HTGR RECYCLE OPS. \\
\hline 12.00 & GA-A-13886 & 76.07 & W/S & HTGR SPENT FUEL COMPOSITION/FUEL ELEMENT BLOCK FLOW \\
\hline 12.00 & GA-A-15145 & 78.10 & W & REPROC. FLOWSHEET/MATERIAL BALANCE/MEU SPENT FUEL \\
\hline 12.00 & GA-A-15180 & 78.12 & W & MEU/TH FUEL CYCLE OPTIMIZATION FOR LEAD PLANT \\
\hline 12.00 & GA-A-17123 & 83.05 & W & SELECTION/LEU/TH REF. FUEL/HTGR-SC/C LEAD PLANT \\
\hline 12.00 & GA-A-18633 & 86.10 & W & MHTGR (NEYLAND-1986) \\
\hline 12.00 & GA-A-19439 & 88.09 & W & ENVIRONMENTAL ASPECTS OF MHTGR OPERATION \\
\hline 12.00 & GA-A-19702 & 89.07 & $\mathbf{W}$ & PERSPECTIVES/MHTGR ON EFFLUENT MGMT. AND SITING \\
\hline 12.00 & NCRP \#81 & 85.01 & $\mathbf{S}$ & CARBON-14 IN THE ENVIRONMENT \\
\hline 12.00 & ORNL-4760 & 71.09 & S & GAS- COOLED REACTOR AND THORIUM UTIL. PROGRAMS \\
\hline
\end{tabular}




\begin{tabular}{|c|c|c|c|c|}
\hline TOPIC & NUMBER $^{6}$ & $\overline{\text { DATE }}$ & LOCATION $^{\mathrm{C}}$ & TITLE \\
\hline 12.00 & ORNLNFW-81/34 & 82.01 & $\mathbf{S}$ & INTEGRATED DATA BASE PROGRAM \\
\hline 12.00 & ORNL/NFW-19/20 & 79.00 & $\bar{A}$ & PROGRAM PLAN FOR HTGR FUEL RECYCLE DEV. \\
\hline 13.00 & $\begin{array}{c}\text { DOCKFT NO. 50- } \\
267\end{array}$ & 88.07 & $\mathrm{~W} / \mathrm{S}$ & FSV UPDATED FSAR, REVISION 6 \\
\hline 13.00 & DOE/RW-0184. V.7 & 88.06 & W/S & $\begin{array}{l}\text { CHARAC./SPENT FUEL/HIGH-LEVVILL WASTE/LOONG-TERM } \\
\text { ISOLATION }\end{array}$ \\
\hline 13.00 & $\mathrm{GA} \cdot \mathrm{A} \cdot 12985$ & 74.12 & w & HTGR CORE THERMAL DESIGN METHODS \& ANAL YSIS \\
\hline 13.00 & $\mathrm{GA} \cdot \mathrm{A} \cdot 13072$ & 74.12 & w & HTGR FUEL DESIGN AND PERFORMANCE \\
\hline 13.00 & GA-A-14140 & 77.02 & W/S & HTGR SPENT FUEL/DECAY HEAT/SOURCE TERM ANALYSIS \\
\hline 13.00 & GA-A-15216 & 79.07 & W & FSV MEU PROGRAM FINAL REPORT \\
\hline 13.00 & GA-A16829 & 82.10 & $\bar{s}$ & $\begin{array}{l}\text { NONDEST. EXAM. OF } 54 \text { FUEL AND FEFL. ELEM. FROM FSV CORE } \\
\text { SEG.2 }\end{array}$ \\
\hline 13.00 & GA-A-17123 & 83.05 & W/S & SELECTION/LEU/TH REF. FUELAHTGR-SC/C L.LADD PLANT \\
\hline 13.00 & $\mathrm{GA} \cdot \mathrm{A} \cdot 17469$ & 84.03 & $\mathrm{~s}$ & REMOTE EXAM. OF FSV HTGR FUEL AND FEEHL. ELEMENTS \\
\hline 13.00 & GA-A-18633 & 86.10 & w & MHTGR (NEYLAND-1986) \\
\hline 13.00 & ORNL-TM-4397 & 74.07 & $\bar{S}$ & $\begin{array}{l}\text { IRRAD. TEST OF CAND. HTGR RECYCLE FUELS IN THE H-1/H-2 } \\
\text { CAPSULES }\end{array}$ \\
\hline 13.00 & ORNL-TM-5049 & 76.02 & $\mathrm{~s}$ & $\begin{array}{l}\text { ASSESS. OF RADIO. IMPACT OF U232 \& DAU. IN RECY. U233 HT'GR } \\
\text { FUEL }\end{array}$ \\
\hline 14.00 & GA-A-18888 & 87.07 & W & SAFETY AND LICENSING OF MHTGR \\
\hline 14.00 & GERHTR-93 & 73.12 & $\bar{w}$ & $\begin{array}{l}\text { ANALYSIS/MATERIAL ACCOUNTING/REPRO. HTGR NUCLEAR } \\
\text { FUELS }\end{array}$ \\
\hline 14.00 & JUL-1350 & 76.10 & w & CRITICALITY INVEST.FBC OF HTR ELEMENTS \\
\hline 15.00 & $\mathrm{GA} \cdot \mathrm{A} \cdot 14508$ & 77.09 & W & INITIAL PERF, EVAL/MAJOR COMPONENTS/SOLIDS HANDLING SYS. \\
\hline 15.00 & GA-A-14705 & 78.04 & w & PNEUMATIC CONVEYING IN HTGR NFP \\
\hline 15.00 & $\mathrm{ICP}-1165$ & 78.08 & W/S & ROVER PROCESS STUDIES/SINTERED METAL FILTERS BL.OWBACK \\
\hline 15.00 & $\mathrm{ICP} \cdot 1160$ & 78.09 & W/S & ROVER PROCESS VERIF. STUDDIES/TRANSPORT/DR Y SOLIDS \\
\hline 15.00 & ICP-1166 & 78.09 & $\mathrm{~W} / \mathrm{S}$ & ROVER PROCESS VERIF. STUDDIES/IRANSPORT/DRY SOLIDS \\
\hline 16.00 & GA-A-14125 & 76.12 & $\bar{w}$ & INTERIM DESIGN STATUS/OP. REP./REMOTE HIANDLING FIXTURES \\
\hline 16.00 & GA-A-14634 & 77.10 & $\bar{w}$ & $\begin{array}{l}\text { SELECTION/TESTING OF ON-LINE SAMPLERS FOR HEADEND } \\
\text { REPRO. }\end{array}$ \\
\hline 21.00 & GA-A-14126 & 77.07 & W & SEMI-REMOTE HANDLING FIXTURES \\
\hline 21.00 & GA-A15262 & 79.04 & $\mathrm{~s}$ & HTGR SPENT FUEL STORAGE STUDY \\
\hline 21.00 & ICP-1052 & 76.01 & W & FSAR/IFSF \\
\hline 22.00 & $\mathrm{GA} \cdot \mathrm{A}-16258$ & 81.05 & W/S & POSTIRR. EXAM \& EVAL. OF FSVF \\
\hline 24.00 & GA-A-14510 & 77.08 & W & DESIGN EVAL./.20 M-SEC. BURNER SYSTEM \\
\hline 24.00 & GA-A-14542 & 77.09 & w & PDR. 20 -M SEC. BURNER SYSTEM \\
\hline 24.00 & ICP-1147 & 78.03 & W/S & PILOT PLANT VERIFICATION/ROVER SEC. BURNER \\
\hline 25.00 & GA-A-15014 & 78.06 & w & CONTINUOUS SOLVENT EXTRACT. FEED/HTGR \\
\hline 25.00 & GA-A-15092 & 78.08 & w & DISSOLUTION/HTGR FUEL REPRO/IDR \\
\hline 25.00 & GA-A-15298 & 79.04 & W/S & DISSOLUTION SYS. DESCRIPTION \\
\hline 25.00 & GA-A-15374 & 79.07 & W & CONTINUOUS SOLVENT EXTR. FEED PREP/TFR \\
\hline 26.00 & $\mathrm{GA}-\mathrm{A}-13860$ & 76.05 & $\mathrm{~s}$ & HTGR SPENT REFLECTOR BLK. DISPOSAL \\
\hline 26.00 & ORNL.6007 & 84.04 & $\bar{W}$ & FIRST YEAR EVAL.NONDESTRUCTIVE ASSAY SYS/TRU \\
\hline 26.00 & ORNL.6103 & 84.04 & W & NEUTRON/GAMMA-RAY NONDES. EXAM/TRANSU. WAS'TE/TRU \\
\hline 26.00 & ORNL-TM-6610 & 76.00 & $\mathrm{~W}$ & DESIGN/EVAL/NONDES. FISSILE ASSAY DEVICE/TTGR \\
\hline 26.00 & ORNL-TM-6960 & na & W & DESIGN/EVAL/ON-LINE FUEL ROD ASSAY DEVICE/HTGR \\
\hline
\end{tabular}




\begin{tabular}{|c|c|c|c|c|}
\hline TOPIC & NUMBER $^{b}$ & DATE & LOCATIONC & TITLE \\
\hline 27.00 & $\mathrm{ICP} \cdot 1073$ & 75.06 & W/S & EVAL. CONTINUOUS SOLID BOWL. CENTRIFUGE/ROVER \\
\hline 28.00 & $G A \cdot A \cdot 14126$ & 77.02 & $\mathbf{W}$ & SEMI-REMOTE HANDLING FIXTURES \\
\hline 28.010 & $G \Lambda \cdot A \cdot 14645$ & 77.12 & W & UNIFRAME IDR \\
\hline 28.00 & GA.A-14838 & $78.1) 6$ & W & HTGR FUEL ELEMENT SIZE REDUCTION SYS. \\
\hline 28.00 & GA-A-14859 & 78.06 & $\mathbf{W} / \mathbf{S}$ & DESIGN/EVAL./HTGR FUEL ELEMENT SIZE REDUCTION \\
\hline 29.00 & $G A \cdot A \cdot 13546$ & 76.01 & $\bar{S}$ & INTER. DEV. REPORT FOR PRIMARY BURNING \\
\hline 29.00 & GA-A-14327 & 77.03 & $\mathrm{~W} / \mathrm{S}$ & FLUID. COMBUSTION/BEDS/LARGE PARTICL.ES/HTGR \\
\hline 29.00 & GA-A-14452 & 77.06 & $\mathrm{~W} / \mathrm{S}$ & DESIGN EVAL. 40-CM PRIMARY BURNER SYSTEM \\
\hline 29.00 & GA-A-14643 & 77.12 & $\mathrm{~W}$ & .20-M PRIMARY BURNER DEVEL. REPORT \\
\hline 29.00 & GA-A-14816 & 78.04 & $\bar{W}$ & PDR: .40-M PRIMARY BURNER SYSTEM \\
\hline 29.00 & $G A \cdot A \cdot 15088$ & 78.09 & W & PDR- .20-M PRIMARY BURNER SYSTEM \\
\hline 29.00 & GA-A-15540 & 79.08 & W & COMBUSTION/C-FINES BY ABOVE-BED RECYCLE/AFBB \\
\hline 29.00 & GEHTR-145 & 75.01 & W & HTR HEADEND COMP.SHAFT FURNACE/FBP \\
\hline 29.00 & ICP-1068 & 75.06 & W/S & PRIMARY GRAPHITE BURNER TEST-W/O FINES RECYCLE \\
\hline 29.00 & ICP-1069 & 75.05 & W/S & FINES RECYCLE TEST/4-in. PRIMARY GRAPHIITE BURNER \\
\hline 30.00 & GA-A.13135 & 75.06 & W/S & PNEUMATIC CLASSIFICATION/FSVF \\
\hline 30.00 & GA-A-14860 & 79.10 & W & DESIGN EVAL./PNEUMATIC TRANSPORT/CLASSIFICATION \\
\hline 30.00 & ORNL-TM-5091 & na & A & na \\
\hline 30.00 & $G A \cdot A \cdot 14930$ & 78.07 & $\mathbf{w}$ & PARTICLE CLASSIFIER/HTGR REPRO. \\
\hline 30.00 & ICP.1051 & 74.04 & $\bar{W} / \mathrm{S}$ & GAS CLASS. METHIODISEPARATING FSV TRISO-TRISO FUEL \\
\hline 31.00 & GA.A-14675 & 77.11 & W & IDR: FUEL PARTICLE CRUSHING \\
\hline 31.00 & GA-A-14957 & 78.10 & W & HTGR PARTICLE CRUSHER DESIGN EVAL. \\
\hline 31.00 & GA-A-15073 & 78.09 & $\mathbf{W}$ & IDR: ENG. SCALE PARTICLE CRUSHER \\
\hline 31.00 & GA-A-15447 & 79.06 & W & HTGR PARTICLE CRUSHER/MARK I DESIGN \\
\hline 31.00 & DDS-8.90 & na & A & na \\
\hline 31.00 & ICP. 1043 & 74.04 & $\mathbf{W} / \mathbf{S}$ & BREAKING SI-C COATED UNIRRADIATED FSVF PARTICLES \\
\hline 31.00 & ICP-1062 & 75.03 & W/S & IER: BREAKING SI-CARBIDE: COATINGS/FSVF/GAS JET \\
\hline 31.00 & ICP-1070 & 75.04 & W/S & EXP. TEST/DOUBLE-ROLL CRUSHER ON FSVF \\
\hline 32.00 & CONF-720823 & 72.08 & $\bar{s}$ & $\begin{array}{l}\text { EST. PRO. DE. FACT. REQ. TO MEET FED. EFF. REG. BURN. HTGR } \\
\text { FUEL ELE. }\end{array}$ \\
\hline 32.00 & GA-A-13174 & 74.11 & $\mathrm{~S}$ & CARBON-14 IN THE HTGR FUEL CYCLE \\
\hline 32.00 & GA-A-17634 & 84.06 & $\mathrm{~W} / \mathrm{S}$ & TEST RESULTS/ENG.-SCALE OFF-GAS TREATMENT SYS. \\
\hline 32.00 & GERHTR-109 & 74.08 & W & AKUT/SEP. OF AEROSOLS, KR AND H3/BURNER OFF-GAS/HTR \\
\hline 32.00 & GERHTR-136 & 74.07 & W & TREATMENTNOLATILE RADIONUC. IN FUEL REPRO. PLANTS \\
\hline 32.00 & GERHTR-153 & 76.02 & W & AKUT II/EXP. PLANT/PURIFYING HTG LOOP/WASTE GAS \\
\hline 32.00 & GERHTR-176 & 77.00 & $\mathbf{W}$ & POSS./LIMIT./ELECTROSTATIC PRECIP/REPRO. INSTALL. \\
\hline 32.00 & IAEA-SM-245/29 & na & S & PROCESSES FOR THE CONTROL OF 14 CO2 DURING REPROCESSING \\
\hline 32.00 & ICP-1137 & 78.04 & W/S & ZEOLITE SIEVE 3A/ADSORP. TRITIATED H20 VAPOR/HTGR OFF-GAS \\
\hline 32.00 & JUL-1223 & 75.07 & W & HANDLING/SEPARATION/H3, NOBLE GASSES, I IN REPRO. FAC. \\
\hline 32.00 & JUL-1238 & 75.10 & W & BEHAVIOR/H3 IN REACTOR GRAPHITE \\
\hline 32.00 & JUL-1295 & 76.05 & $\mathrm{~W} / \mathrm{S}$ & RELEASE/GASEOUS FISSION PROD/FUEL ELE. GAS-COOL. HTR \\
\hline 32.00 & JUL-1567 & 79.00 & A & C-14 REDUCTION ALTERNATIVES \\
\hline 32.00 & ORNL-4859 & 73.04 & $\mathbf{S}$ & CAL. ON THE PERFORMANCE OF THE KAL.C PROCESS \\
\hline 32.00 & ORNL-4962 & na & W & DEVEL/CEMENTITIOUS GROUTS FOR INCORP/RADIO. WASTES/I \\
\hline 32.00 & ORNL-5142 & na & W & DEVEL/CEMENTITIOUS GROUPS FOR INCORP./RADIO. WASTES/II \\
\hline
\end{tabular}




\begin{tabular}{|c|c|c|c|c|}
\hline TOPIC & NUMBER $^{6}$ & DATE & LOCATIONC $^{c}$ & TITLE \\
\hline 32.00 & ORNL-6100 & 86.01 & $\bar{W}$ & $\mathrm{Ba}(\mathrm{OH}) 2.8 \mathrm{H} 20$ PROCESS/REMOVAL AND IMM. OF C-14 \\
\hline 32.00 & ORNL-TM-3527 & 72.07 & $\mathbf{S}$ & $\begin{array}{l}\text { HTGR HEADEND PRO: PRE. EVAL. PROC. DECON. BURNER OFF. } \\
\text { GAS }\end{array}$ \\
\hline 32.00 & ORNL-TM-5171 & 76.04 & W/S & EVAL. OPTIONS/FLXATION/DISPOSAL/14-C CONTAM. CO2/CaCO3 \\
\hline 32.00 & ORNL-TM-5757 & 78.03 & $\mathbf{W}$ & $\begin{array}{l}\text { EXP/LINE SLURRY/STIRRED TANK/FIXATION C-14 FROM CO2 OFF- } \\
\text { GAS }\end{array}$ \\
\hline 32.00 & ORNL-TM-6539 & 82.06 & $\mathrm{~W} / \mathrm{S}$ & EXP. INVES./DISTRIB. OF KR/HTGR OFF.GAS \\
\hline 32.00 & ORNL-TM-6607 & na & W & $\begin{array}{l}\text { LIT. SURVEY/METHODS/I REMOVAL. FROM OFF-GAS/SOLID } \\
\text { SORBENTS }\end{array}$ \\
\hline 32.00 & ORNL-TM-6642 & na & $\mathbf{W} / \mathbf{S}$ & BEHAVIOR/I IN HEAD-END REPRO. OF HTGR FUEL: [-129 STUDIES \\
\hline 32.00 & ORNL-TM-7338 & 80.07 & W/S & PROCESSES FOR CONTROL/14-CO2 DURING REPRO. \\
\hline 32.00 & ORNL-TM-7693 & na & W & C-14 IMMOBIL./CO2-BA(OH)2 HYDRATE GAS-SOLID REACTION \\
\hline 32.00 & ORNL-TM-8261 & 82.08 & $\overline{\mathrm{W}}$ & EVAL/RETENTION/DISPOSAL OPTIONS FOR H3/FUEL REPRO. \\
\hline 32.00 & ORNL-TM-8284 & 82.11 & $\bar{W}$ & SORPTION/DESORPTION BEHAVIOR/I ON GRAPHITE \\
\hline 32.00 & ORNL-TM-8579 & 83.03 & W & CEMENT-BASED RAD. WASTE HOSTS UNDER TEMP. AND PRES. \\
\hline 32.00 & $\begin{array}{l}\text { ORNLNNUREG/T } \\
\quad \mathrm{M} \cdot 12\end{array}$ & 77.02 & $\mathrm{~W} / \mathrm{S}$ & C.14 PRODUCTION IN NUC. REACTORS \\
\hline 32.00 & $\begin{array}{l}\text { ORNL/NUREG. } \\
\text { TM-4 }\end{array}$ & 76.05 & S & $\begin{array}{l}\text { COR. OF RAD. WASTE TREAT. COST/REPRO. HTGR FUEL W/U-233 } \\
\text { \&TH }\end{array}$ \\
\hline 32.00 & GA-A.15224 & 82.08 & $\bar{W}$ & I AND RU VOLATILITY IN TFR \\
\hline 33.00 & GA-A-15224 & 79.01 & W & I AND RU VOLATILITY IN TFR \\
\hline 33.00 & GERHTR-150 & 76.03 & $\mathrm{~W} / \mathrm{S}$ & CRYOGENIC SEP./KR AND XENON FROM DISSOLVER OFF.GAS \\
\hline 33.00 & ORNL-TM-7782 & 81.08 & W & UTIL. OF ZEOLITES FOR LIQUID RADWASTE CLEANUP \\
\hline 34.00 & GA-A-15014 & 78.06 & $\mathbf{W}$ & CONTINUOUS SOLVENT EXTRACT. FEED ADJUST/HTGR \\
\hline 34.00 & GA-A.15030 & 78.07 & W & SOLVENT EXTRACTION/HTGR REPRO. \\
\hline 34.00 & GA-A-15030 & 78.07 & $\mathbf{W}$ & SOLVENT EXTRACTION/HTGR REPRO. \\
\hline 34.00 & GA-A-15155 & 78.10 & $\mathbf{W}$ & ALTERNATE FUEL CYCLE TECHNOLOGIES \\
\hline 35.00 & ORNL/TM-11016 & 90.01 & $\bar{S}$ & $\begin{array}{l}\text { NON-LWR \& SPEC. LWR SPENT FUELS: CHAR. \& CRIT. OF PACK. } \\
\text { AND DIS. }\end{array}$ \\
\hline 35.00 & ORNL-TM-12027 & 92.02 & $\bar{S}$ & OPTIONS FOR TREAT. HTGR FUEL FOR REP. DISPOSAL \\
\hline 35.00 & QCD 2751-A58 & 89.09 & $\mathbf{S}$ & SPENT FUEL OXIDATION TESTING \\
\hline 35.00 & CONF-910945-88 & 91.09 & $\mathrm{~S}$ & CAD. CONTAINER MAT. FOR YUCCA MOUNTAIN WASTE PACK. DES. \\
\hline 36.00 & ORNL-3542 & 64.08 & W & EFFECTS OF TEMP. ON FISSION-PRODUCT DEPOSITION \\
\hline 36.00 & HMI-B-372 & 83.06 & $\mathbf{S}$ & $\begin{array}{l}\text { A REV. OF DIF. OF SELECTED FISSION PRO. METALS IN POLY. } \\
\text { GRAPHITE }\end{array}$ \\
\hline 36.00 & IAEA-SM-200/81 & 75.01 & $\mathbf{S}$ & FISSION PROD. RETEN. \& FUEL DEV. FOR ADVANCED HTRS \\
\hline 36.00 & ORNL-TM-4519 & 74.01 & $\bar{S}$ & $\begin{array}{l}\text { HTGR FUEL REP: WHL-BLCK BURN. W/REC. OF COOL GAS FOR } \\
\text { TEM. CONT. }\end{array}$ \\
\hline 36.00 & EUR 9232 & 84 & $\mathbf{S}$ & $\begin{array}{l}\text { ASSESS. OF MGMT. MODES FOR GRAPHITE FROM REACTOR } \\
\text { DECOM. }\end{array}$ \\
\hline 36.00 & EUR 9474 & 84 & $\bar{S}$ & MANAGEMENT AND DISPOSAL OF GRAPHITE WASTE \\
\hline
\end{tabular}

a. Source: Drake Engineering Inc. HTGR Processing Bibliographies, with additions and modifications.

b. Date Code: identifies year and month document was published.

c. Location:

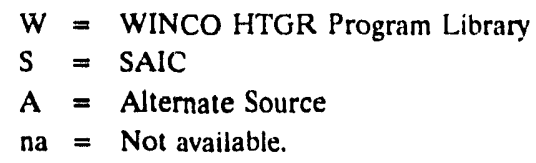




\section{TOPIC LEGEND}

$\begin{aligned} 1.00 & \text { PROGRESS REPORTS } \\ 2.00 & \text { GRAPHITE DATA } \\ 3.00 & \text { GENERAL HEADEND } \\ 4.00 & \text { GRIND LEACH } \\ 5.00 & \text { BURN LEACH } \\ 6.00 & \text { GASSIFICATION } \\ 7.00 & \text { HALOGENATION } \\ 8.00 & \text { ELECTROLYTIC DECONSOLIDATION } \\ 9.00 & \text { ROVER DEVELOPMENT } \\ 10.00 & \text { AQUEOUS PROCESSING } \\ 11.00 & \text { BIBLIOGRAPHIES } \\ 12.00 & \text { GENERAL FUEL CYCLE INFORMATION } \\ 13.00 & \text { FUEL DESIGN AND CHARACTERISTICS } \\ 14.00 & \text { SAFETY AND LICENSING } \\ 15.00 & \text { SOLIDS TRANSPORT } \\ 16.00 & \text { REMOTE HANDLING } \\ 21.00 & \text { FUEL RETRIEVAL } \\ 22.00 & \text { ROD REMOVAL } \\ 23.00 & \text { CRUSH RODS AND PARTICLES } \\ 24.00 & \text { BURN BROKEN PARTICLES } \\ 25.00 & \text { DISSOLVE BURNER ASH (PUREX AND THOREX) } \\ 26.00 & \text { DISPOSE OF EMPTY BLOCKS } \\ 27.00 & \text { DISPOSE OF INSOLUBLES } \\ 28.00 & \text { CRUSH FUEL ELEMENTS } \\ 29.00 & \text { BURN GRAPHITE MATRIX } \\ 30.00 & \text { SEPARATE PARTICLES } \\ 31.00 & \text { CRUSH PARTICLES } \\ 32.00 & \text { TREAT BURNER OFF-GAS (BOG) } \\ 33.00 & \text { TREAT DISSOLVER OFF-GAS (DOG) } \\ 34.00 & \text { SEPARATIONS PROCESSING } \\ 35.00 & \text { DIRECT WHOLE BLOCK DISPOSAL } \\ 36.00 & \text { MISCELLANEOUS } \\ & \end{aligned}$




\section{Appendix B}

\section{Estimated Radionuclide Activity \\ in Fort St. Vrain Standard Full Elements}

B-1 
B-2 


\section{Appendix B}

\section{Estimated Radionuclide Activity in Fort St. Vrain Standard Fuel Elements}

\section{Data and Assumptions}

1. ORIGEN code isotopic concentration data for 6-year irradiation time and 10-year decay time (i.e., 100,000 MWd/MTIHM) from DOE/RW-0184-R1 ${ }^{1}$

2. $50 \%$ reduction in ORIGEN code equilibrium core (i.e., 100,000 MWd/MTIHM) data to allow for actual burnup recorded for fuel (i.e., $\leq 47,000 \mathrm{MWd} / \mathrm{MTIHM}$ ) (DOE RW-0184-R1) ${ }^{1}$

3. $2.8 \mathrm{~g}$ of initial heavy metal (IHM) per 2 in. long fuel rod (DOE RW-0184-R1) ${ }^{1}$

4. $3 \%$ rod breakage from in-pile as well as rod-removal failure (GA-A16258)

5. 3130 fuel rods ( 2 in. long) per standard fuel element (FE) (GA-A16258) ${ }^{2}$

6. $86 \mathrm{~kg}$ carbon per standard fuel element body

7. $\sim 0.0610 \mathrm{~m}^{3}$ of carbon per standard fuel element body

8. Two fuel kernel breakage assumptions were used:

a. $\quad 100 \%$ fuel kernel breakage per broken fuel rod

b. $5 \%$ fuel kernel breakage per broken fuel rod (Fitzgerald, et al.). ${ }^{3}$

The 5\% particle breakage was determined during a head-end reprocessing study using test fuel rods similar to Fort St. Vrain (FSV) fuel rods in dimension and TRISO-coated fissile particles distributed in a graphite matrix. However, the rods were dissimilar in that the FSV fertile fuel kernels are also TRISO-coated [i.e., have silicon carbide (SiC) hulls] whereas the fuel test elementfour (FTE-4) test element fertile kernels were BISO-coated (i.e., no SiC hulls). Therefore, the 5\% particle breakage during crushing and primary burning of the FTE-4 test element rods is only representative of how a TRISO-coated fissile particle may be affected by crushing or breakage.

These calculations were performed only to provide a general estimate of the magnitude of the problem of classifying the empty FSV graphite blocks as low level waste. 


\section{Calculations}

Total rod breakage:

$(0.03) \times(3130 \mathrm{rods} / \mathrm{FE})=93.9$ use 94 rods.

Total heavy metal released per fuel element (100\% fuel kernel breakage): $\left(2.8 \times 10^{-6} \mathrm{MTIHM} / \mathrm{rod}\right) \times(94 \mathrm{rods} / \mathrm{FE})=0.0003 \mathrm{MTIHM} / \mathrm{FE}$

Total heavy metal released per fuel element (5\% fuel kernel breakage):

(0.05) $\times\left(2.8 \times 10^{-6} \mathrm{MTIHM} / \mathrm{FE}\right) \times(94$ fuel rods/FE) $=1.5 \mathrm{E}-05 \mathrm{MTIHM} / \mathrm{FE}$

Volumetric Concentration:

$100 \%$ fuel kernel breakage:

ORIGEN value $\left[\right.$ Ci/MTIHM] $0.5 \times 0.0003$ [MTIHM/FE] $\div 0.0610\left[\mathrm{~m}^{3} \mathrm{carbon} / \mathrm{FE}\right]$

$5 \%$ fuel kernel breakage:

ORIGEN value [Ci/MTIHM] $\times 0.5 \times 1.5 E-05$ [MTIHM/FE] $\div 0.0610\left[\mathrm{~m}^{3}\right.$ carbon/FE]

Mass Concentration:

100\% fuel kernel breakage:

ORIGEN value [Ci/MTIHM] $\times 1.0 E+09$ [nCi/Ci] $\times 0.5 \times 0.0003$ [MTIHM/FE] $\div 8.6 \times 10^{4}[\mathrm{~g}$ carbon/FE]

$5 \%$ fuel kernel breakage:

ORIGEN value [Ci/MTIHM] $\times 1.0 E+09$ [nCi/Ci] $\times 0.5 \times 1.5 E-05[M T I H M / F E] \div 8.6 \times 10^{4}$ [g carbon/FE]

Using these basic equations, the estimated radionuclide activity per mass and volume of carbon in a FSV fuel element was calculated and compared with the Nuclear Regulatory Commission's low-level waste classification criteria. Only those radionuclides listed in the 10 CFR 61.55 Tables 1 and 2 with specific limits are calculated here. 
Fission Products:

$\underline{\text { Nuclide }}$

Sr-90:

Cs-137:

I-129:
$100 \%$ breakage

$545.9 \mathrm{Ci} / \mathrm{m}^{3}$

$562.1 \mathrm{Ci} / \mathrm{m}^{3}$

3.1E-07 Ci $/ \mathrm{m}^{3}$
$5 \%$ breakage

$27.3 \mathrm{Ci} / \mathrm{m}^{3}$

$28.1 \mathrm{Ci} / \mathrm{m}^{3}$

$1.5 \mathrm{E}-08 \mathrm{Ci} / \mathrm{m}^{3}$
Class-C limit

$7,000 \mathrm{Ci} / \mathrm{m}^{3}$ $4,600 \mathrm{Ci} / \mathrm{m}^{3}$

$0.080 \mathrm{Ci} / \mathrm{m}^{3}$

Transuranics $w / t^{1 / 2}>5$ years:

$\underline{\text { Nuclide }}$

Np-237:

Pu-238:

Pu-239:

Pu-240:

Am-241:

Am-242m:

Am-242:

Am-243:

Cm-243:

Cm-244:

Other Transuranics:

$\underline{\text { Nuclide }}$

Pu-241:

Cm-242:
$100 \%$ breakage

$1.73 \mathrm{nCi} / \mathrm{g}$ 17,406 nCi.g

$14.9 \mathrm{nCi} / \mathrm{g}$

$14.0 \mathrm{nCi} / \mathrm{g}$

$106.3 \mathrm{nCi} / \mathrm{g}$

$0.89 \mathrm{nCi} / \mathrm{g}$

$0.89 \mathrm{nCi} / \mathrm{g}$

$5.72 \mathrm{nCi} / \mathrm{g}$

$1.21 \mathrm{nCi} / \mathrm{g}$

$659.1 \mathrm{nCi} / \mathrm{g}$
$5 \%$ breakage

$0.08 \mathrm{nCi} / \mathrm{g}$

$852.3 \mathrm{nCi} / \mathrm{g}$

$0.74 \mathrm{nCi} / \mathrm{g}$

$0.70 \mathrm{nCi} / \mathrm{g}$

$5.31 \mathrm{nCi} / \mathrm{g}$

$0.04 \mathrm{nCi} / \mathrm{g}$

$0.04 \mathrm{nCi} / \mathrm{g}$

$0.29 \mathrm{nCi} / \mathrm{g}$

$0.06 \mathrm{nCi} / \mathrm{g}$

$\underline{32.9 \mathrm{nCi} / \mathrm{g}}$
Class-C limit

$100 \mathrm{nCi} / \mathrm{g}$

"I

"

"

II

II

"

"1

"

$\frac{11}{100 \mathrm{nCi} / \mathrm{g}}$

5\% breakage

$237.6 \mathrm{nCi} / \mathrm{g}$

$0.04 \mathrm{nCi} / \mathrm{g}$ $\underline{\text { Class-C limit }}$

$3,500 \mathrm{nCi} / \mathrm{g}$

$20,000 \mathrm{nCi} / \mathrm{g}$ 
<smiles>C1CCCC1</smiles> 

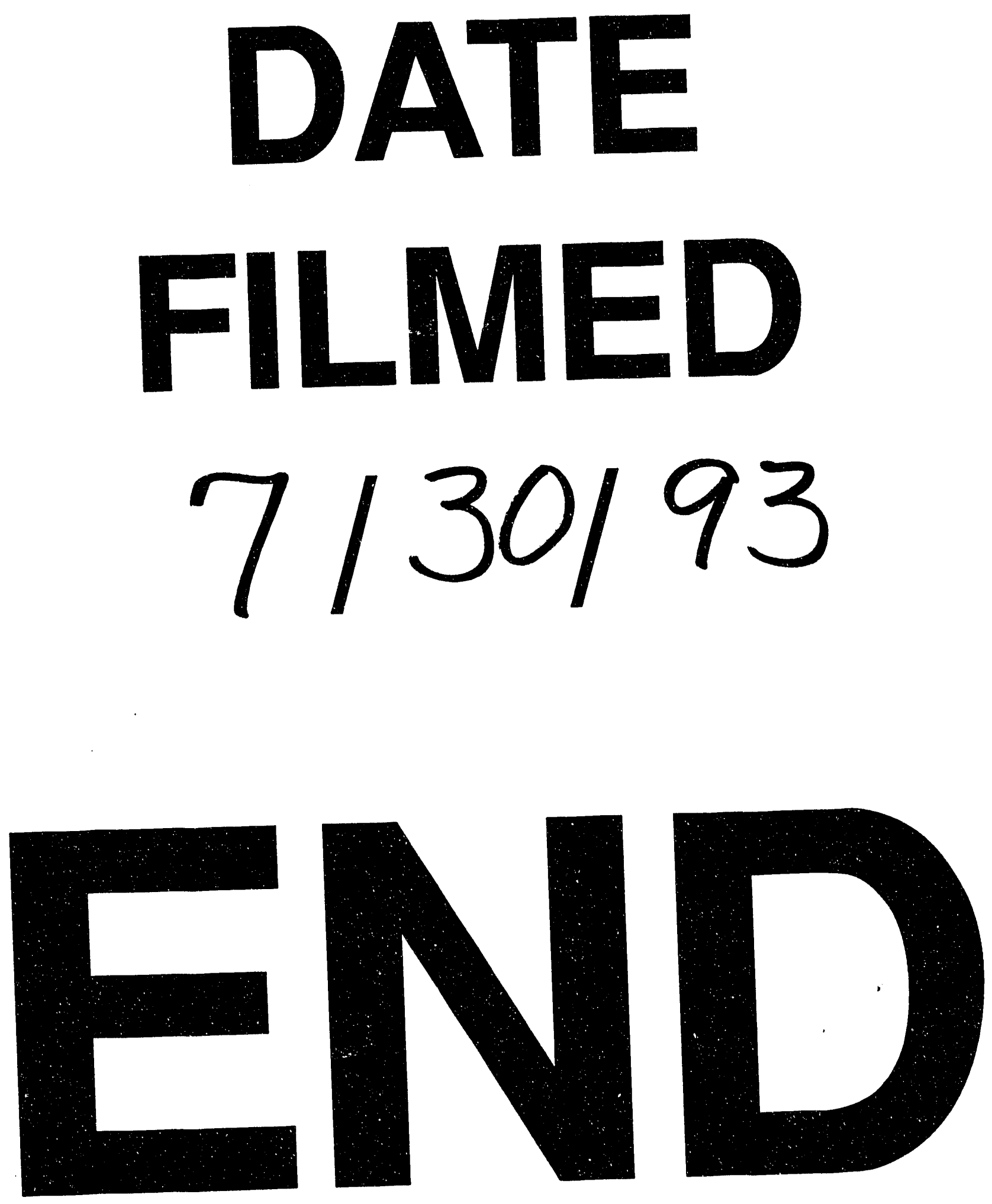
